\title{
Ninth Annual Report to Congress
}

\section{Fiscal Year 1995 Progress in Implementing Section 120 of the}

\section{Comprehensive}

\section{Environmental}

Response,

Compensation, and

\section{Liability}

Act

RUSTRIBUTION OF THIS DOCUMENT IS UNLIMITED

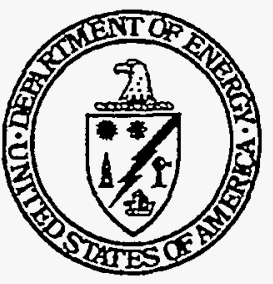

United States Department of Energy 


\section{DISCLAIMER}

This report was prepared as an account of work sponsored by an agency of the linited States Government. Neither the United States Government nor any agency thereof. nor any of their employees, make any warranty, express or implied, or assumes any legal liability or responsibility for the accuracy, completeness. or usefulness of any information. apparatus, product. or process disclosed, or represents that its use would not infringe privately owned rights. Reference herein to any specific commercial product, process. or service by trade name, trademark, manufacturer. or otherwise does not necessarily constitute or imply its endorsement, recommendation or favoring by the United States Government or any agency thereof. The views and opinions of authors expressed herein do not necessarily state or reflect those of the United States Government or any agency thereof. 


\section{DISCLAMIER}

Portions of this document may be illegible in electronic image products. Images are produced from the best available original cocument. 


\section{TABLE OF CONTENTS}

$\underline{\text { Page }}$

EXECUTIVE SUMMARY $\ldots \ldots \ldots \ldots \ldots \ldots \ldots \ldots \ldots \ldots \ldots \ldots \ldots \ldots$

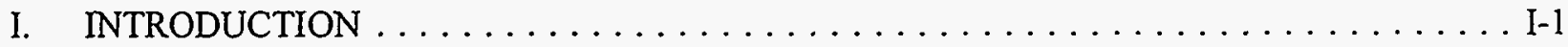

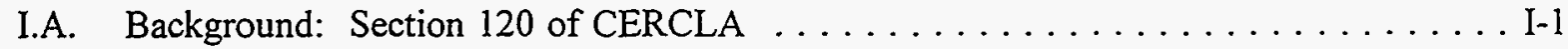

I.B. CERCLA Section 120(e)(5): Annual Report to Congress . . . . . . . . . . . . . . I-3

I.C. Overview of DOE Facilities Subject to CERCLA Section $120 \ldots \ldots \ldots \ldots \ldots \ldots$. $\ldots \ldots$

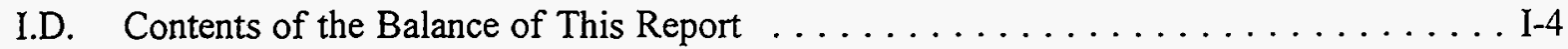

II. DOE CERCLA COMPLIANCE STRATEGY $\ldots \ldots \ldots \ldots \ldots \ldots \ldots \ldots \ldots \ldots$ II-1

II.A. DOE Organizations Responsible for CERCLA Compliance $\ldots \ldots \ldots \ldots \ldots \ldots$. . II-1

II.B. Legal Context for DOE's Remediation Activities $\ldots \ldots \ldots \ldots \ldots \ldots \ldots \ldots \ldots$ II-2

II.C. Environmental Contamination at DOE Facilities . . . . . . . . . . . . . II-2

II.D. EM Approach to Environmental Restoration $\ldots \ldots \ldots \ldots \ldots \ldots \ldots \ldots$. . . . . . .

II.E. Related EM Efforts . . . . . . . . . . . . . . . . . . . II-10

II.F. Approach to Environmental Restoration Used by Other DOE Organizations . . . . II-12

III. STATUS OF CERCLA ACTIVITIES AT DEPARTMENT OF ENERGY SITES $\ldots . . .$. III-1

III.A. Progress in Reaching Interagency Agreements . . . . . . . . . . . . . . III-1

III.B. Specific Cost Estimates and Budgetary Proposals to Support Environmental

Restoration Activities Required by the IAG . . . . . . . . . . . . . III-1

III.C. Public Comments Regarding Proposed Interagency Agreements . . . . . . . . . . . . III-4

III.D. Instances in Which No Interagency Agreement Was Reached . . . . . . . . . . III-4

III.E. Progress in Conducting Remedial Investigations/Feasibility

Studies at NPL Sites $\ldots \ldots \ldots \ldots \ldots \ldots \ldots \ldots \ldots \ldots$ III-4

III.F. Progress in Conducting Remedial Actions at NPL Sites $\ldots \ldots \ldots \ldots \ldots \ldots \ldots$ III-5

III.G. Progress in Conducting Removal and Interim Actions at NPL Sites . . . . . . . . III-6

III.H. Progress in Performing Cleanup Activities at Facilities Not on the NPL . . . . . . III-8

IV. SITE SUMMARIES FOR FACILITIES ON THE NPL (BY STATE) $\ldots \ldots \ldots \ldots \ldots$ IV-1

V. SITE SUMMARIES FOR SELECTED FACILITIES NOT ON THE NPL (BY STATE) ... V-1

APPENDIX A List of Acronyms and Abbreviations $\ldots \ldots \ldots \ldots \ldots \ldots \ldots \ldots$

APPENDIX $B$ Index of Individual Facilities $\ldots \ldots \ldots \ldots \ldots \ldots \ldots \ldots \ldots \ldots \ldots$ 


\section{LIST OF FIGURES}

Page

Figure I-1 Locations of All DOE Facilities Subject to Section 120 of CERCLA . . . . . . I-6

Figure II-1 DOE Facilities/Sites in the Nuclear Weapons Complex and Subject to Section 120 of CERCLA . . . . . . . . . . . . . . . . . II-4

Figure II-2 DOE Facilities/Sites Subject to Section 120 of CERCLA and Not in the Nuclear Weapons Complex . . . . . . . . . . . . . . . . II-6

\section{LIST OF TABLES}

Table ES-1 U.S. Department of Energy Facilities on the National Priorities List . . . . . . ES-2 Table I-1 Status of All DOE Facilities/Sites Subject to Section 120 of CERCLA . . . . . . . I-8

Table III-1 U.S. Department of Energy Facilities on the National Priorities List . . . . . . . III-2

Table IV-1 Status of FEMP Removal Actions $\ldots \ldots \ldots \ldots \ldots \ldots \ldots \ldots \ldots$ 
EXECUTIVE SUMMARY 


\section{EXECUTIVE SUMMARY}

\section{BACKGROUND}

Congress passed the Comprehensive Environmental Response, Compensation, and Liability Act (CERCLA) (Public Law 96-510), commonly known as Superfund, in 1980. The Superfund Amendments and Reauthorization Act (SARA) (Public Law 99-499), which amended CERCLA in 1986, added Section 120 regarding the cleanup of contaminated sites at Federal facilities.

Under Section 120(e)(5) of CERCLA, each department, agency, or instrumentality of the Federal government responsible for compliance with Section 120 must submit an annual report to Congress concerning its progress in implementing the requirements of Section 120. The report must include information on the progress in reaching Interagency Agreements (IAGs), conducting Remedial Investigation and Feasibility Studies (RJ/FSs), and performing remedial actions. Federal agencies that own or operate facilities on the National Priorities List (NPL) are required to begin an R//FS for these facilities within 6 months after being placed on the NPL. Remediation of these facilities is addressed in an IAG between the Federal agency, the U.S. Environmental Protection Agency (EPA), and in some instances the state within which the facility is located.

This report, prepared by the U.S. Department of Energy's (DOE's) Office of Environmental Management, is being submitted to Congress in accordance with Section 120(e)(5) of CERCLA. It is DOE's Ninth Annual Report to Congress and provides information on DOE's progress in implementing CERCLA Section 120 in Fiscal Year 1995 (FY 95), i.e., from October 1, 1994, to September 30, 1995.

\section{CURRENT STATUS}

There are 99 DOE facilities subject to CERCLA Section 120 and 23 DOE facilities on the NPL. DOE's NPL facilities are presented by state on Table ES-1. Table ES-1 also includes information relating to when each facility was placed on the NPL and the status of the IAG for the facility. No new facilities were placed on the NPL in FY 95; however, the three facilities placed on the NPL in FY 94 have not yet entered into IAGs. The other 20 facilities are conducting remedial activities as specified in their IAGs.

\section{REPORT CONTENTS AND ORGANIZATION}

This report provides the status of ongoing activities being performed in support of CERCLA Section 120 at DOE facilities. This includes activities conducted to reach IAGs and progress in conducting remedial actions.

Section I describes Section 120 of CERCLA, the requirements of the Annual Report to Congress, and the DOE facilities subject to Section 120 of CERCLA.

Section II describes DOE's CERCLA compliance strategy and identifies the:

- DOE organizations responsible for CERCLA compliance,

- Legal context for DOE's remediation activities,

- Causes of environmental contamination at DOE facilities, 
Table ES-1. U.S. Department of Energy Facilities on the National Priorities List

\begin{tabular}{|c|c|c|c|}
\hline STATE & SITE NAME & $\begin{array}{l}\text { DATE OF FR' NOTICE } \\
\text { OF NPL LISTING } \\
\end{array}$ & INTERAGENCY AGREEMENT (IAG) STATUS \\
\hline \multirow[t]{3}{*}{ California } & $\begin{array}{l}\text { Laboratory for Energy-Related Health } \\
\text { Research (LEHR) }\end{array}$ & $05 / 31 / 94$ & $\begin{array}{l}\text { Memorandum of Agreement with University of California, Davis, } \\
\text { signed in 1989, revised 1993; Federal Facility Agreement and the } \\
\text { Potentially Responsible Party Agreement are currently being } \\
\text { negotiated. }\end{array}$ \\
\hline & $\begin{array}{l}\text { Lawrence Livermore National } \\
\text { Laboratory - Livermore Site }\end{array}$ & $07 / 22 / 87$ & Federal Facility Agreement executed on November 1, 1988. \\
\hline & $\begin{array}{l}\text { Lawrence Livermore National } \\
\text { Laboratory - Site } 300\end{array}$ & $08 / 30 / 90$ & Federal Facility Agreement signed on June 29, 1992. \\
\hline Colorado & $\begin{array}{l}\text { Rocky Flats Environmental } \\
\text { Technology Site (formerly the Rocky } \\
\text { Flats Plant) }\end{array}$ & $10 / 04 / 89$ & $\begin{array}{l}\text { IAG executed on January } 22,1991 \text {; currently under renegotiation; the } \\
\text { new Compliance Agreement is expected to be signed in the fourth } \\
\text { quarter of FY } 96 \text { following public comment. }\end{array}$ \\
\hline Idaho & \begin{tabular}{|l} 
Idaho National Engineering \\
Laboratory (includes Argonne \\
National Laboratory - West)
\end{tabular} & $11 / 21 / 89$ & $\begin{array}{l}\text { Federal Facility Agreement/Consent Order executed on } \\
\text { December } 9,1991 .\end{array}$ \\
\hline Kentucky & Paducah Gaseous Diffusion Plant & $05 / 31 / 94$ & IAG under negotiation. \\
\hline \multirow[t]{2}{*}{ Missouri } & $\begin{array}{l}\text { St. Louis Site (includes St. Louis } \\
\text { Airport Site and Vicinity Properties, } \\
\text { Latty Avenue Properties) }\end{array}$ & $10 / 04 / 89$ & Federal Facility Agreement signed on June 26, 1990. \\
\hline & $\begin{array}{l}\text { Weldon Spring Site Remedial Action } \\
\text { Projcct (formerly referred to as } \\
\text { Weldon Spring Quarry and Feed } \\
\text { Materials Plant and Raffinate Pits } \\
\text { Site) }\end{array}$ & $\begin{array}{l}07 / 22 / 87 \\
03 / 13 / 89^{3}\end{array}$ & $\begin{array}{l}\text { Federal Facility Agreement signed on August 22, 1986; amended } \\
\text { June 30, 1992. }\end{array}$ \\
\hline \multirow[t]{2}{*}{ New Jersey } & Maywood Site ${ }^{2}$ & $09 / 08 / 83$ & $\begin{array}{l}\text { Federal Facility Agreement signed on July 23, 1990, and made } \\
\text { effective in April } 1991 .\end{array}$ \\
\hline & Wayne Site $^{2}$ & $09 / 21 / 84$ & $\begin{array}{l}\text { Federal Facility Agreement signed on July 23, 1990, and made } \\
\text { effective in April } 1991 .\end{array}$ \\
\hline New York & Brookhaven National Laboratory & $11 / 21 / 89$ & IAG executed on February 28, 1992, and made effective May 27, 1992 \\
\hline
\end{tabular}


Table ES-1. U.S. Department of Energy Facilities on the National Priorities List (Continued)

\begin{tabular}{|c|c|c|c|}
\hline STATE & SITE NAME & $\begin{array}{l}\text { DATE OF FR' NOTICE } \\
\text { OF NPL LISTING }\end{array}$ & INTERAGENCY AGREEMENT (IAG) STATUS - \\
\hline \multirow[t]{2}{*}{ Ohio } & $\begin{array}{l}\text { Fernald Environmental Management } \\
\text { Project }\end{array}$ & $11 / 21 / 89$ & $\begin{array}{l}\text { Consent Agreement made effective on June 29, 1990; amended on } \\
\text { September 20,1991 and April 5,1993. }\end{array}$ \\
\hline & Mound Plant & $11 / 21 / 89$ & $\begin{array}{l}\text { Federal Facility Agreement executed on August } 6,1990 \text {; amended on } \\
\text { July } 15,1993 \text {. }\end{array}$ \\
\hline South Carolina & Savannah River Site & $11 / 21 / 89$ & $\begin{array}{l}\text { IAG executed on January } 15,1993 \text {, and made effective on August } 16 \text {, } \\
1993 .\end{array}$ \\
\hline Tennessee & Oak Ridge Reservation & $11 / 21 / 89$ & IAG made effective on January $1,1992$. \\
\hline Texas & Pantex Plant & $05 / 31 / 94$ & Federal Facility Agreement under negotiation. \\
\hline \multirow[t]{2}{*}{ Utah } & Monticello Mill Site & $11 / 21 / 89$ & Federal Facility Agreement executed on December 22, $1988 .{ }^{4}$ \\
\hline & Monticello Vicinity Properties & $06 / 10 / 86$ & Federal Facility Agreement executed on December $22,1988{ }^{4}$ \\
\hline \multirow[t]{5}{*}{ Washington } & Hanford Site - Area 100 & $10 / 04 / 89$ & $\begin{array}{l}\text { Tri-Party Agreement signed on May 15, 1989; amended in 1991, } 1992 \text {, } \\
1994 \text {, and on July } 28,1995 \text {. }\end{array}$ \\
\hline & Hanford Site - Area 200 & $10 / 04 / 89$ & $\begin{array}{l}\text { Tri-Party Agreement signed on May 15, 1989; amended in 1991, 1992, } \\
\text { 1994, and on July 28, } 1995 \text {. }\end{array}$ \\
\hline & Hanford Site - Area 300 & $10 / 04 / 89$ & $\begin{array}{l}\text { Tri-Party Agreement signed on May 15, 1989; amended in 1991, 1992, } \\
1994 \text {, and on July 28, } 1995 \text {. }\end{array}$ \\
\hline & Hanford Site - Area 1100 & $10 / 04 / 89$ & $\begin{array}{l}\text { Tri-Party Agreement signed on May 15, 1989; amended in 1991, 1992, } \\
1994 \text {, and on July 28, } 1995 \text {. }\end{array}$ \\
\hline & $\begin{array}{l}\text { Ross Complex (part of the Bonneville } \\
\text { Power Administration) }\end{array}$ & $11 / 21 / 89$ & IAG executed on May I, 1990. \\
\hline
\end{tabular}

$\mathrm{FR}=$ Federal Register

2 Congress directed DOE to remediate these sites. The states (New Jersey and Missouri) are not parties to these IAGs.

3 The Feed Materials Plant and Raffinate Pits were added to the site $3 / 13 / 89$.

4 One IAG was developed for both Monticello sites, but the sites are listed separately on the NPL. 
- DOE approach to environmental restoration, and

- DOE activities related to CERCLA 120 compliance.

Section III provides a discussion of DOE's overall progress in reaching IAGs and responding to public comments regarding proposed IAGs. It also identifies instances where no IAG has been concluded. Section III further provides highlights on progress in conducting RU/FSs, remedial actions, and response activities at NPL facilities, and in performing cleanup activities at facilities not on the NPL.

Section IV provides a detailed description of the status of each NPL facility subject to CERCLA Section 120 on a state-by-state basis. Included in this section is a description of the hazards presented, plans and schedules for initiating and completing response actions, enforcement status (where appropriate), and an explanation of any postponements or failure to complete a response action. This section identifies DOE's FY 95 funding, appropriated FY 96 funding, and funding requested in the President's Budget for FY 97 for environmental restoration at each NPL facility.

Section V provides a description of the remediation status of non-NPL facilities (by state) subject to CERCLA Section 120 where 1995 CERCLA funding was more than $\$ 1$ million.

Appendix A is a list of the acronyms and abbreviations used in this report. Appendix B is an alphabetical listing of the facilities discussed in this report by facility name, showing the pages in the report on which their primary information is discussed. 
SECTION I

INTRODUCTION

$$
-9 r^{n}
$$




\section{INTRODUCTION}

\section{I.A. Background: Section 120 of CERCLA}

Congress passed the Comprehensive Environmental Response, Compensation, and Liability Act (CERCLA) (Public Law 96-510), commonly known as Superfund, in 1980. The primary goal of the Act is to encourage the identification and remediation of sites contaminated with hazardous substances.

The Superfund Amendments and Reauthorization Act (SARA) (Public Law 99-499), which amended CERCLA in 1986, added certain specific provisions applicable to the cleanup of contaminated sites at Federal facilities. These provisions, located in Section 120 of CERCLA, are briefly described below.

Under Section 120(a)(1), CERCLA specifies that Federal departments, agencies, and instrumentalities must comply with CERCLA in the same manner and to the same extent as nongovernmental entities. Except for requirements applicable to bonding, insurance, or financial responsibility, all guidelines, rules, regulations and criteria applicable to preliminary assessments (PAs), National Contingency Plan (NCP) evaluations, inclusion on the National Priorities List (NPL), and the conduct of remedial action are applicable to contaminated sites at Federal facilities (Sections 120(a)(2),(3),(4)).

Even before the passage of SARA, Federal agencies were required to identify sites where hazardous waste was treated, stored, or disposed of at any time. SARA added Section 120(b), which requires Federal agencies to also identify contamination affecting contiguous or adjacent property and any monitoring data associated with this contamination.

Section 120(c) of CERCLA requires the U.S. Environmental Protection Agency (EPA) to compile information about contaminated sites at Federal facilities and to enter the information into the Federal Agency Hazardous Waste Compliance Docket (the docket). The docket must also include information about Federal facilities where hazardous wastes are generated and managed under Sections 3005 and 3010 of Resource Conservation and Recovery Act (RCRA), even if these facilities are not contaminated.

To compile the docket, each Federal Agency, including DOE, notifies EPA of hazardous waste activity under:

- CERCLA Section 103 (notification of a release or potential release);

- RCRA Section 3005 (permitting authority);

- RCRA Section 3010 (notification of hazardous waste activity for generators, transporters, and treatment, storage, and disposal facilities); and

- RCRA Section 3016 (biennial inventory of hazardous waste treatment, storage, and disposal facilities).

Certain Federal facilities that conduct hazardous waste activities under these sections of CERCLA and RCRA are, however, exempt from docket listing. These facilities include small quantity generators of hazardous waste (generators of less than $1,000 \mathrm{~kg} /$ month of hazardous waste) and facilities that notify EPA of hazardous waste activity under Section 3010 of RCRA only because they are transporters of hazardous waste. 
Information submitted to EPA under the above requirements is entered into several EPA databases. EPA extracts the information from the databases to compile a proposed update to the docket that is provided to Federal agencies, including DOE. DOE reviews the proposed docket update and provides formal comments to EPA headquarters.

A facility is listed on the docket with a code that relates to the facility's NPL status. The NPL is EPA's list of the most serious or abandoned hazardous waste sites identified for long-term remedial action under CERCLA. Sites are placed on the NPL if they receive a threshold score from EPA's Hazard Ranking System. Docket status codes and their meanings are as follows:

U Undetermined

N Site Evaluation Accomplished (SEA)

P Currently Proposed for the National Priorities List

F Currently Final on the NPL

R Removed from the Proposed NPL and No Longer Considered for the Final NPL

D Deleted from the Final NPL

EPA assigns the $\mathrm{N}$ code, which denotes Site Evaluation Accomplished, to facilities that are not likely to be placed on the NPL and where no further involvement by EPA in site assessment or cleanup is anticipated. (DOE may, however, perform additional response actions at the Site Evaluation Accomplished facilities.)

Section 120(d) of CERCLA requires Federal agencies to conduct a PA of facilities listed on the docket within 18 months after docket listing. If the PA indicates a need for further investigation, the responsible agency must conduct a site investigation (SI). Based on information developed in the PA or Preliminary Assessment/Site Investigation (PA/SI), EPA must determine if: 1) no further remedial action is necessary at this time; or 2) further evaluation and possible inclusion on the NPL are warranted.

Section 120(e) of CERCLA requires Federal agencies that own or operate facilities on the NPL to begin a remedial investigation and feasibility study (RU/FS) for these facilities not later than 6 months after being placed on the NPL. EPA must review the results of each Federal facility RI/FS. Within 180 days after the completion of EPA's review, Federal agencies must enter into interagency agreements (IAGs) with EPA for expeditious completion of remedial action at the facility. The contents of IAGs must include:

- A review of alternative remedial actions and selection of a remedial action,

- A schedule for the completion of the remedial action, and

- Arrangements for long-term operation and maintenance of the facility.

Remedial action must begin not later than 15 months after the completion of a RI/FS and must be completed "as expeditiously as practicable." To ensure that adequate funds are appropriated to perform cleanup, Federal agencies must include a statement of the hazards posed to human health, welfare, and the environment by each facility on the NPL. Also, specific consequences of failure to begin and complete remedial action must be identified and included in annual budget submissions to Congress. 


\section{I.B. CERCLA Section 120(e)(5): Annual Report to Congress}

Under Section 120(e)(5) of CERCLA, each department, agency, or instrumentality of the Federal government responsible for compliance with Section 120 must submit an annual report to Congress concerning its progress in implementing the requirements of Section 120 . The report must include information on at least the following items:

- Progress in reaching IAGs under CERCLA Section 120,

- Specific cost estimates and budgetary proposals involved in each IAG,

- A brief summary of the public comments regarding each proposed IAG,

- A description of the instances in which no IAG was reached,

- Progress in conducting RI/FSs,

- Progress in conducting remedial actions,

- Progress in conducting remedial actions at facilities which are not on the NPL,

- An explanation of any failure to conclude an IAG within 180 days after EPA review, and

- A detailed description on a state-by-state basis of the status of each facility subject to CERCLA Section 120, including a description of the hazards presented by each facility, plans and schedules for initiating and completing response actions, enforcement status (where appropriate), and an explanation of any postponements or failure to complete response actions.

This report is being submitted to Congress in accordance with Section 120(e)(5) of CERCLA. It is the U.S. Department of Energy's (DOE) Ninth Annual Report to Congress under Section 120(e)(5) and provides information on DOE's progress in implementing CERCLA Section 120 in Fiscal Year 1995 (FY 95), i.e., from October 1, 1994, to September 30, 1995.

\section{I.C. Overview of DOE Facilities Subject to CERCLA Section 120}

Figure I-1 (presented at the end of this section on pages I-6 to I-7) shows the location of DOE facilities subject to CERCLA Section 120. These facilities are listed on Table I-1 (presented at the end of this section on pages I-8 to I-26), by state. The table also shows the status of each facility as listed on the docket, the type of contamination present, and the current status of remediation at each facility.

There are 99 DOE facilities subject to CERCLA 120 shown on Table I-1. Six of these facilities were removed from the docket in FY 95 because they are no longer subject to Section 120 of CERCLA (West Valley Demonstration Project, New York; Lapine (BPA), Oregon; Cosmopolis (BPA), Maple Valley Substation (BPA), Monroe (BPA), and Snow King Substation (BPA), Washington). These facilities are included on the table as a courtesy in this report, even though they are no longer subject to Section 120 of CERCLA. They will not be included in subsequent reports.

The table includes one facility, the Pittsburgh Energy Technology Center, for which DOE is not listed as the responsible Federal Agency on the April 1995 updated docket. DOE believes this to be an error 
and therefore has included the Pittsburgh Energy Technology Center on the table. Previous docket updates correctly listed the Pittsburgh Energy Technology Center as a DOE facility.

The table does not include the United States Enrichment Corporation, a wholly owned U.S. government corporation created by the Energy Policy Act of 1992. The Corporation performs hazardous waste activities under contract to DOE as an operator of DOE's Paducah Gaseous Diffusion Plant (Kentucky) and Portsmouth Uranium Enrichment Complex (Ohio). EPA included the United States Enrichment Corporation on the docket in the State of Ohio and identified DOE as the Federal agency responsible for the United States Enrichment Corporation in the most recent docket update. However, DOE believes the docket listing to be incorrect because the DOE-owned facilities where United States Enrichment Corporation generates hazardous waste as a site operator, the Paducah Gaseous Diffusion Plant (Kentucky) and the Portsmouth Uranium Enrichment Complex (Ohio), are already listed on the docket.

DOE also believes that the April 1995 docket listing for DOE's Carlsbad Area Office in Carlsbad, New Mexico is an error and has not included the Carlsbad Area office on Table I-1. The Carlsbad Area office administers DOE's Waste Isolation Pilot Plant in New Mexico. The Waste Isolation Pilot Plant is already on the docket.

Two of the facilities on Table I-1, the St. Louis Site in Missouri and the Monticello Vicinity Properties, are privately owned; thus, they are not included on the docket. DOE, however, is responsible for cleanup of these sites as established by Congressional mandate. Both of these facilities are listed on the NPL.

Two DOE facilities are listed differently on Table I-1 than by EPA on the docket.

- Ostrander Substation (BPA) (Oregon) on Table I-1 is listed on the docket as Oregon City (BPA). DOE has notified EPA of the correct name of this facility.

- $\quad$ EPA listed Sandia National Laboratory/Nevada (Tonopah) on the docket on April 11, 1995. DOE has informed EPA that this facility is the Tonopah Test Range (Nevada) and is already on the docket.

Twenty-three of the facilities on Table I-1 are on the NPL. However, DOE's Hanford facility, which is listed once on the docket, has four NPL entries. Each NPL entry covers a discrete contaminated area (i.e., areas 100, 200,300, and 1100).

No DOE facility is currently proposed for the NPL, and no DOE facility has been removed from the NPL.

In an August 1995 memorandum, EPA advised its regional offices that Federal facilities are not listed on the NPL on a fenceline-to-fenceline basis. Only the contaminated areas are considered Superfund sites by EPA, even if the name of the site implies that it covers the entire facility. Future NPL rulemaking notices will contain revised language clarifying this point.

\section{I.D. Contents of the Balance of This Report}

This report presents information on contaminated sites at DOE facilities that were placed on the NPL as of September 1995, and on facilities on the docket as of April 11, 1995 (Docket Number 9). These 
versions of the NPL and docket were the last versions published before FY 95 ended. Information on DOE sites and facilities placed on the NPL or docket after FY 95 ended will be included in subsequent CERCLA reports to Congress. In this section of the report and in subsequent sections, the words "site" and "facility" are used interchangeably.

This report does not contain information on DOE remedial activities at sites that have not been placed on the docket and thus are not subject to the requirements of Section 120 of CERCLA. These sites may include 1) NPL sites that are not owned by DOE (such as the Maxey Flats Disposal Site in Kentucky, where DOE has been named as a Potentially Responsible Party), 2) Uranium Mill Tailings Remedial Action (UMTRA) project sites, 3) sites in the Formerly Utilized Sites Remedial Action Program (FUSRAP), and 4) non-DOE sites that became contaminated as a result of nuclear research and development activities sponsored by DOE and its precursors.

Section II describes DOE's CERCLA compliance strategy and identifies the:

- DOE organizations responsible for CERCLA compliance,

- Legal context for DOE's remediation activities,

- Causes of environmental contamination at DOE facilities,

- DOE approach to environmental restoration, and

- DOE activities related to CERCLA 120 compliance.

Environmental Management (EM) activities related to CERCLA 120 include DOE's production of the Baseline Environmental Management Report, Waste Management Programmatic Environmental Impact Statement, and Site Treatment Plans under the Federal Facility Compliance Act, as well as DOE's participation on the Federal Facilities Environmental Dialogue Committee. CERCLA compliance activities performed by the Western Area Power Administration, Pittsburgh Energy Technology Center, Bonneville Power Administration, and the Morgantown Energy Technology Center are also described in this section.

Section III provides a discussion of DOE's overall progress in reaching IAGs and responding to public comments regarding proposed IAGs. It also identifies instances where no IAG has been concluded. Section III further provides highlights on progress in conducting RI/FSs, remedial actions, and response activities at NPL sites, and in performing cleanup activities at sites not on the NPL.

Section IV provides a detailed description of the status of each NPL facility subject to CERCLA Section 120 on a state-by-state basis. Included in this section is a description of the hazards presented, plans and schedules for initiating and completing response actions, enforcement status (where appropriate), and an explanation of any postponements or failure to complete response action. This section identifies DOE's FY 95 funding, appropriated FY 96 funding, and funding requested in the President's Budget for FY 97 for environmental restoration at each NPL facility.

Section $V$ provides a description of the remediation status of non-NPL facilities (by state) subject to CERCLA Section 120 where 1995 CERCLA funding was more than $\$ 1$ million.

Appendix $\mathbf{A}$ is a list of the acronyms and abbreviations used in this report.

Appendix B is an alphabetical listing of the facilities discussed in this report by facility name showing the pages in the report on which their primary information is discussed. 


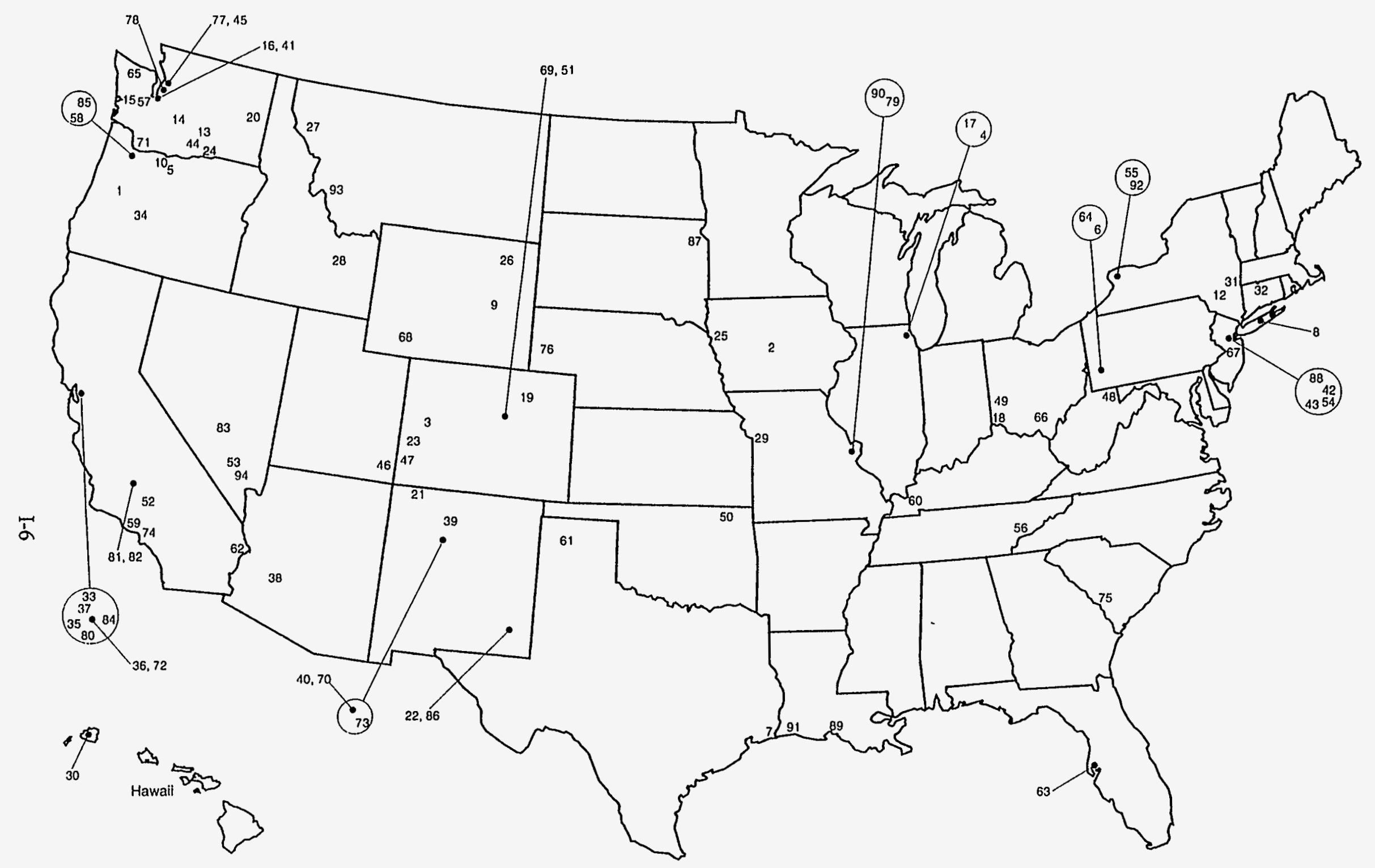

Figure 1-1. Locations of All DOE Facilities/Sites Subject to Section 120 of CERCLA. 
Alvey Maintenance Headquarters, $O R$

Ames Laboratory, IA

Anvil Points Facility, Naval Oil Shale Reserve No. 3, CO

Argonne National Laboratory - East, IL

Bake Oven Substation, OR

Bettis Atomic Power Laboratory, West Mifflin, PA

Big Hill Site, TX

Brookhaven National Laboratory, NY

Casper Field Branch, WY

Celilo Converter Station, OR

Center for Energy and Environmental Research, PR

Colonie Site, NY

Columbia Basin Project AEC Zone 2,4-D Site, WA

Columbia Substation, WA

Cosmopolis, WA

Covington Substation, WA

Fermi National Accelerator Laboratory, IL

18* Fernald Environmental Management Project, $\mathrm{OH}$

Fort Morgan Substation, CO

G.H. Bell Substation and Maintenance Complex, WA

Gasbuggy, NM

Gnome-Coach, NM

Grand Junction Projects Office Remedial Action Project, CO

24* Hanford Site, WA

25 Hinton Hazardous Waste Storage Facility, IA

27 Hot Springs Substation TLM Complex, MT

28* Idaho National Engineering Laboratory, ID

29 Kansas City Plant, MO

30 Kauai Test Facility, H

31 Knolls Atomic Power Laboratory, Niskayuna and West Milton Sites, NY

32 Knolls Atomic Power Laboratory, Windsor Site, CT

33* Laboratory for Energy-Related Health Research, CA

34 Lapine, OR

35 Lawrence Berkeley National Laboratory, CA

36* Lawrence Livermore National Laboratory - Livermore Site, CA

37* Lawrence Livermore National Laboratory - Site 300, CA

38 Liberty Substation, AZ

39 Los Alamos National Laboratory, NM

40 Lovelace Inhalation Toxicology Research Institute, NM

41 Maple Valley Substation, WA

42* Maywood Site, NJ

43 Middlesex Sampling Plant, NJ

44 Midway Substation, WA

45 Monroe, WA

46* Monticello Mill Site and Monticello Vicinity Properties, UT

47 Montrose Power Operations Center, $\mathrm{CO}$

48 Morgantown Energy Technology Center, WV

49* Mound Plant, $\mathrm{OH}$

50 National Institute for Petroleum and Energy Research, OK

51 National Renewable Energy Laboratory, CO

52 Naval Petroleum Reserve Nos. 1 \& 2 , CA

53 Nevada Test Site, NV

54 New Brunswick Laboratory, NJ

S5 Niagara Falls Storage Site, NY

56* Oak Ridge Reservation, TN

57 Olynupia Substation, WA

58 Ostrander Substation, OR (Oregon City, OR)

59 Oxnard Facility, CA

60* Paducah Gaseous Diffusion Plant, $\mathrm{KY}$

61* Pantex Plant, TX

62 Parker Dam Switchyard, CA

63 Pinellas Plant, FL

64 Pittsburgh Energy Technology Center, PA

65 Port Angeles, WA

66 Portsmouth Uranium Enrichment Complex, $\mathrm{OH}$

67 Princeton Plasma Plyysics Laboratory, NJ

68 Rock Springs Oil Shale Retort, WY

69* Rocky Flats Environmental Technology Site, $\mathrm{CO}$

70 Ross Aviation, Inc., NM

71* Ross Complex, WA

72 Sandia National Laboratories/California, CA

73 Sandia National Laboratories/New Mexico, NM

74 Santa Susana Field Laboratories, CA

75* Savannah River Site, SC

76 Sishc Foundry Site, NE

77 Snohomisli Substation, WA

78 Snow King Substation, WA

79* St. Louis Site, MO

80 Stanford Linear Accelerator Center, $C A$

81 Texaco Section 8 Central Solid Waste Site, CA

82 Texaco Section 8 Gas Plant, CA

83 Tonopalı Test Range, NV (Sandia National Laboratories/Tonopah)

84 Tracy Pump and Substation, $\mathrm{CA}$

85 Troutdale Substation, OR

86 Waste Isolation Pilot Plant, NM (Carlsbad, NM)

87 Watertown Maintenance Facility, SD

88* Wayne Site, NJ

89 Weeks Island, LA

90* Weldon Spring Site Remedial Action Project, MO

91 West Hackberry Site, LA

92 West Valley Demonstration Project, NY

93 Western Environmental Technology Office, $M T$

94 Yucca Mouttain Site, NV

* NPL Site

Figure I-1. Locations of all DOE Facilities/Sites Subject to Section 120 of CERCLA - Key (Continued). 
Table I-1. Status of All DOE Facilities/Sites Subject to Section 120 of CERCLA'

\begin{tabular}{|c|c|c|c|}
\hline STATE & DOE FACILITY & $\begin{array}{l}\text { DOCKET } \\
\text { STATUS }\end{array}$ & TYPE OF CONTAMINATION/STATUS OF REMEDIATION \\
\hline Arizona & Liberty Substation (WAPA) & $\mathrm{U}$ & $\begin{array}{l}\text { Onsite soil/chemical contamination. } \\
\text { PA completed in FY } 93 \text { and submitted to EPA. The site is awaiting response from } \\
\text { EPA Region IX regarding PA. }\end{array}$ \\
\hline \multirow[t]{4}{*}{ California } & $\begin{array}{l}\text { Laboratory for Energy-Related } \\
\text { Health Research (LEHR) }\end{array}$ & F & $\begin{array}{l}\text { Onsite soil and potential offsite groundwater/chemical and radioactive contamination. } \\
\text { The Federal Facility Agreement is currently being negotiated. The RI/FS Work Plan } \\
\text { has been implemented. DOE and the University of California-Davis are negotiating } \\
\text { liability and cost-sharing for the non-DOE source areas of contamination (Potentially } \\
\text { Responsible Party Agreement). }\end{array}$ \\
\hline & $\begin{array}{l}\text { Lawrence Berkeley National } \\
\text { Laboratory }\end{array}$ & N & $\begin{array}{l}\text { Onsite soil and groundwater/chemical and radioactive contamination. } \\
\text { The first RCRA Facility Investigation (RFI) progress report was submitted in } \\
\text { November 1994, with a second expected early in FY } 96 .\end{array}$ \\
\hline & $\begin{array}{l}\text { Lawrence Livermore National } \\
\text { Laboratory - Livermore Site }\end{array}$ & $\mathrm{F}$ & $\begin{array}{l}\text { Onsite groundwater, soil/chemical, and offsite groundwater contamination. } \\
\text { The Livermore Site issued Remedial Design Reports } 5 \text { and } 6 \text {, completed a draft } \\
\text { Compliance Monitoring Plan, and began operation of the Building } 518 \text { vapor } \\
\text { extraction system. The Livermore Site continues to operate } 5 \text { groundwater treatment } \\
\text { facilities, and the hydraulic control of the western offsite plume has been established. }\end{array}$ \\
\hline & $\begin{array}{l}\text { Lawrence Livermore National } \\
\text { Laboratory - Site } 300\end{array}$ & F & $\begin{array}{l}\text { Onsite groundwater, soil/chemical, radioactive, and offsite groundwater } \\
\text { contamination. } \\
\text { CERCLA requirements for LLNL - Site } 300 \text { have been restructured and streamlined. } \\
\text { The Feasibility Study (FS) for the General Services Area Operable Unit (OU) and the } \\
\text { Interim Record of Decision (ROD) for the Building } 834 \text { OU have been completed. } \\
\text { The interim soil vapor extraction facility was restarted. }\end{array}$ \\
\hline
\end{tabular}


Table I-1. Status of All DOE Facilities/Sites Subject to Section 120 of CERCLA' (Continued)

\begin{tabular}{|c|c|c|c|}
\hline STATE & DOE FACILITY & $\begin{array}{l}\text { DOCKET } \\
\text { STATUS }\end{array}$ & TYPE OF CONTAMINATION/STATUS OF REMEDIATION \\
\hline \multirow[t]{6}{*}{$\begin{array}{l}\text { California } \\
\text { (Continued) }\end{array}$} & $\begin{array}{l}\text { Naval Petroleum Reserve } \\
\text { Nos. } 1 \text { and } 2\end{array}$ & $\mathrm{U}$ & $\begin{array}{l}\text { Onsite soil/chemical contamination. } \\
\text { The site has been characterized as Site Evaluation Accomplished. }\end{array}$ \\
\hline & Oxnard Facility & $\mathrm{U}$ & $\begin{array}{l}\text { Onsite suspected soil and groundwater/chemical contamination. } \\
\text { A Phase II Assessment revealed potential polychlorinated biphenyl (PCB) } \\
\text { contamination in soils. Further action is pending in FY } 96 .\end{array}$ \\
\hline & $\begin{array}{l}\text { Parker Dam Switchyard } \\
\text { (WAPA) }\end{array}$ & $\mathrm{U}$ & $\begin{array}{l}\text { Onsite soil/chemical contamination. } \\
\text { The PA was completed in FY 93. The site is awaiting response from EPA Region IX. }\end{array}$ \\
\hline & $\begin{array}{l}\text { Sandia National Laboratories/ } \\
\text { California }\end{array}$ & $U$ & $\begin{array}{l}\text { Onsite soil and groundwater/chemical contamination. } \\
\text { The site completed construction of the in-situ bioremediation pilot study at the Fuel } \\
\text { Oil Spill Site in FY } 95 \text {, and the first injection phase of the bioremediation phase } \\
\text { began in June 1995. Additional groundwater monitoring continues at the Navy } \\
\text { Landfill. }\end{array}$ \\
\hline & $\begin{array}{l}\text { Santa Susana Field Laboratories } \\
\text { (Energy Technology Engineering } \\
\text { Center) }\end{array}$ & $\mathrm{U}$ & $\begin{array}{l}\text { Onsite groundwater and soil/chemical and radioactive contamination; offsite } \\
\text { groundwater/chemical and radioactive contamination. } \\
\text { Groundwater investigations are continuing under RCRA and the Regional Water } \\
\text { Quality Control Board (RWQCB) authorities. A site-wide RFI is in progress. An RFI } \\
\text { Work Plan was submitted in March 1995, and the site is awaiting comments from the } \\
\text { state. The RFI schedule will be adjusted as needed, once comments are received. }\end{array}$ \\
\hline & $\begin{array}{l}\text { Stanford Linear Accelerator } \\
\text { Center }\end{array}$ & $\mathrm{N}$ & $\begin{array}{l}\text { Onsite groundwater and soil/chemical contamination; offsite soil/PCB contamination. } \\
\text { The Remedial Investigation (RI) is in progress. PCB contamination at Interaction } \\
\text { Region } 6 \text { and } 8 \text { drainage has been removed and the site has been restored to natural } \\
\text { controls. }\end{array}$ \\
\hline
\end{tabular}


Table I-1. Status of All DOE Facilities/Sites Subject to Section 120 of CERCLA' (Continued)

\begin{tabular}{|c|c|c|c|}
\hline STATE & DOE FACILITY & $\begin{array}{l}\text { DOCKET } \\
\text { STATUS }\end{array}$ & TYPE OF CONTAMINATION/STATUS OF REMEDIATION \\
\hline \multirow[t]{3}{*}{$\begin{array}{l}\text { California } \\
\text { (Continued) }\end{array}$} & $\begin{array}{l}\text { Texaco Section } 8 \text { Central Solid } \\
\text { Waste Site }\end{array}$ & $\mathrm{N}^{2}$ & $\begin{array}{l}\text { Contamination unknown. } \\
\text { Site characterized as Site Evaluation Accomplished. }\end{array}$ \\
\hline & Texaco Section 8 Gas Plant & $\mathrm{N}^{2}$ & $\begin{array}{l}\text { Contamination unknown. } \\
\text { Site characterized as Site Evaluation Accomplished. }\end{array}$ \\
\hline & $\begin{array}{l}\text { Tracy Pump and Substation } \\
\text { (WAPA) }\end{array}$ & $\mathrm{U}$ & $\begin{array}{l}\text { Onsite soil/chemical contamination. } \\
\text { The PA/SI was submitted in FY } 93 \text {. Region IX had indicated in early FY } 94 \text { that no } \\
\text { further action would be required on the site. Site Evaluation Accomplished status is } \\
\text { expected in the next docket. }\end{array}$ \\
\hline \multirow[t]{4}{*}{ Colorado } & $\begin{array}{l}\text { Anvil Points Facility, Naval Oil } \\
\text { Shale Reserve No. } 3\end{array}$ & $\mathrm{~N}$ & $\begin{array}{l}\text { Onsite soil contamination. } \\
\text { Prior to FY 93, the PA was submitted and an SI plan was requested by the State. } \\
\text { A PA/SI document was approved by the EPA in June 1994. The site has been } \\
\text { classified as Site Evaluation Accomplished; however, the site continues sampling to } \\
\text { monitor conditions. }\end{array}$ \\
\hline & $\begin{array}{l}\text { Fort Morgan Substation } \\
\text { (WAPA) }\end{array}$ & $\mathrm{N}^{2}$ & $\begin{array}{l}\text { Onsite soil contamination (oil) with possible groundwater contamination. } \\
\text { A PA/SI was submitted in January 1995. The site was assigned Site Evaluation } \\
\text { Accomplished status in March } 1995 .\end{array}$ \\
\hline & $\begin{array}{l}\text { Grand Junction Projects Office } \\
\text { Remedial Action Project }\end{array}$ & $N$ & $\begin{array}{l}\text { Onsite soil and groundwater/mixed waste contamination. } \\
\text { The site has been classified as Site Evaluation Accomplished. Decommissioning of } \\
\text { two buildings has been completed. }\end{array}$ \\
\hline & $\begin{array}{l}\text { Montrose Power Operations } \\
\text { Center (WAPA) }\end{array}$ & $\mathrm{N}$ & $\begin{array}{l}\text { Onsite soil/chemical contamination. } \\
\text { The site has been classified as Site Evaluation Accomplished. }\end{array}$ \\
\hline
\end{tabular}


Table I-1. Status of All DOE Facilities/Sites Subject to Section 120 of CERCLA' (Continued)

\begin{tabular}{|c|c|c|c|}
\hline STATE & DOE FACILITY & $\begin{array}{l}\text { DOCKET } \\
\text { STATUS }\end{array}$ & TYPE OF CONTAMINATION/STATUS OF REMEDIATION \\
\hline \multirow[t]{2}{*}{$\begin{array}{l}\text { Colorado } \\
\text { (Continued) }\end{array}$} & $\begin{array}{l}\text { National Renewable Energy } \\
\text { Laboratory }\end{array}$ & $\mathrm{N}$ & $\begin{array}{l}\text { None known. } \\
\text { The site has been classified as Site Evaluation Accomplished. }\end{array}$ \\
\hline & $\begin{array}{l}\text { Rocky Flats Environmental } \\
\text { Technology Site (formerly the } \\
\text { Rocky Flats Plant) }\end{array}$ & F & $\begin{array}{l}\text { Onsite groundwater, surface water, and soil/chemical, radioactive, mixed } \\
\text { contamination; offsite soil/radioactive contamination. } \\
\text { Two RODs have been completed and approved by the regulatory agencies. RI work } \\
\text { plans for all } 15 \text { OUs have been approved by the regulatory agencies. Two Interim } \\
\text { Measure/Interim Remedial Action (IM/IRA) decision documents were submitted. Two } \\
\text { final RI reports, } 1 \text { final FS report, and } 10 \text { accelerated actions were completed. }\end{array}$ \\
\hline Connecticut & $\begin{array}{l}\text { Knolls Atomic Power } \\
\text { Laboratory, Windsor Site }\end{array}$ & $N$ & $\begin{array}{l}\text { None known. } \\
\text { The site was classified as Site Evaluation Accomplished in FY 90. No further EPA } \\
\text { action is expected to be required. }\end{array}$ \\
\hline Florida & Pinellas Plant & $\mathrm{U}$ & $\begin{array}{l}\text { Onsite soil and groundwater and offsite groundwater/chemical contamination. } \\
4.5 \text { Acre State Lead CERCLA Site: One Interim Remedial Action (IRA) is being } \\
\text { implemented in FY } 95 . \\
\text { CERCLA Potentially Responsible Party Involvement: One de minimis settlement has } \\
\text { been executed. One CERCLA Section } 104 \text { (e) response has been submitted. } \\
\text { One RFI is under preparation. Three IRAs have been implemented. }\end{array}$ \\
\hline Hawaii & Kauai Test Facility & $\mathrm{U}$ & $\begin{array}{l}\text { Elevated metals in soil at the Rocket Launcher Field. } \\
\text { The PA Report was submitted in January } 1994 \text {. The SI was completed in May 1994; } \\
\text { the SI Report was begun in June } 1994 \text { and was submitted in FY 95. The site is } \\
\text { awaiting response from EPA Region IX. }\end{array}$ \\
\hline
\end{tabular}


Table I-1. Status of All DOE Facilities/Sites Subject to Section 120 of CERCLA' (Continued)

\begin{tabular}{|c|c|c|c|}
\hline STATE & DOE FACILITY & $\begin{array}{l}\text { DOCKET } \\
\text { STATUS }\end{array}$ & TYPE OF CONTAMINATION/STATUS OF REMEDIATION \\
\hline Idaho & $\begin{array}{l}\text { Idaho National Engineering } \\
\text { Laboratory (INEL) } \\
\text { INEL } \\
\\
\text { Argonne National } \\
\text { Laboratory - West }\end{array}$ & $\mathrm{F}$ & $\begin{array}{l}\text { Onsite groundwater and soil/chemical and radioactive contamination. } \\
\text { Three draft RI/FS Scopes of Work, } 3 \text { Remedial Design/Remedial Action (RD/RA) } \\
\text { Scopes of Work, } 8 \text { RI/FS Work Plans, } 1 \text { draft Remedial Action Report, } 2 \text { draft final } \\
\text { Remedial Action Reports, } 4 \text { draft RI/FS Scopes of Work, } 3 \text { draft RI/FS RODs, } \\
1 \text { Treatability Study Report, } 2 \text { draft final RI/FS Reports, and } 1 \text { draft RI/FS Proposed } \\
\text { Plan (PP) were submitted. Three RODs were signed. Two RI/FS Reports and } 2 \text { PPs } \\
\text { were completed. } \\
\text { One draft RI/FS Statement of Work was completed. }\end{array}$ \\
\hline Illinois & $\begin{array}{l}\text { Argonne National Laboratory - } \\
\text { East }\end{array}$ & $\mathrm{U}$ & $\begin{array}{l}\text { Onsite groundwater and soil/chemical and radioactive contamination. } \\
\text { Remedial actions have continued in FY } 95 \text { as voluntary corrective actions in } \\
\text { coordination with the State. }\end{array}$ \\
\hline & $\begin{array}{l}\text { Fermi National Accelerator } \\
\text { Laboratory }\end{array}$ & $\mathrm{N}$ & $\begin{array}{l}\text { Onsite soil and groundwater/chemical contamination. } \\
\text { The PA was submitted to EPA Region V in November 1993. A Preliminary Risk } \\
\text { Assessment for PCB cleanup was completed on February 19, 1993. The site has been } \\
\text { classified as Site Evaluation Accomplished. }\end{array}$ \\
\hline
\end{tabular}


Table I-1. Status of All DOE Facilities/Sites Subject to Section 120 of CERCLA' (Continued)

\begin{tabular}{|c|c|c|c|}
\hline STATE & DOE FACILITY & $\begin{array}{l}\text { DOCKET } \\
\text { STATUS }\end{array}$ & TYPE OF CONTAMINATION/STATUS OF REMEDIATION \\
\hline \multirow[t]{2}{*}{ Iowa } & Ames Laboratory & $\mathrm{U}$ & $\begin{array}{l}\text { Offsite soil/radioactive contamination. } \\
\text { 2,000 cubic yards of contaminated soil and debris were removed and disposed offsite } \\
\text { in FY } 95 \text {. The site cleanup report for the Chemical Disposal Site was submitted to the } \\
\text { state in FY } 95 \text {. The Groundwater Characterization Plan was approved by the State } \\
\text { and is expected to be implemented in FY } 96 .\end{array}$ \\
\hline & $\begin{array}{l}\text { Hinton Hazardous Waste Storage } \\
\text { Facility (WAPA) }\end{array}$ & $\mathrm{N}$ & $\begin{array}{l}\text { Onsite soil/radioactive contamination. } \\
\text { The site was classified as Site Evaluation Accomplished in FY 93. Soil was } \\
\text { incinerated and disposed of in November 1993. Closure was completed in } \\
\text { February } 1995 .\end{array}$ \\
\hline Kentucky & $\begin{array}{l}\text { Paducah Gaseous Diffusion } \\
\text { Plant }^{3}\end{array}$ & $\mathrm{~F}$ & $\begin{array}{l}\text { Onsite and offsite soil contamination concerning PCBs, metals, and radionuclides } \\
\text { characteristic of the uranium enrichment process. Onsite and offsite groundwater } \\
\text { contamination concerning primarily trichloroethylene and technetium-99. There are } \\
\text { two major offsite groundwater plumes. } \\
\text { Two interim action RODs were submitted and signed. Two } 2 \text { RI Work Plans, one RI } \\
\text { addendum, and one Post Construction Report were submitted. One treatability study } \\
\text { and } 2 \text { RI Reports were completed and the Feasibility Study (FS) was begun. }\end{array}$ \\
\hline \multirow[t]{2}{*}{ Louisiana } & Weeks Island (SPRO) & $N$ & $\begin{array}{l}\text { None known. } \\
\text { A determination was made by EPA Region VI on September 16, } 1991 \text { that no PA/SI } \\
\text { was required. The site was classified prior to FY } 93 \text { as Site Evaluation Accomplished. }\end{array}$ \\
\hline & West Hackberry Site (SPRO) & $N$ & $\begin{array}{l}\text { None known. } \\
\text { A determination was made by EPA Region VI on September 16, } 1991 \text { that no PA/SI } \\
\text { was required. The site was classified as Site Evaluation Accomplished in FY } 93 \text {. }\end{array}$ \\
\hline
\end{tabular}


Table I-1. Status of All DOE Facilities/Sites Subject to Section 120 of CERCLA' (Continued)

\begin{tabular}{|c|c|c|c|}
\hline STATE & DOE FACILITY & $\begin{array}{l}\text { DOCKET } \\
\text { STATUS }\end{array}$ & TYPE OF CONTAMINATION/STATUS OF REMEDIATION \\
\hline \multirow[t]{3}{*}{ Missouri } & Kansas City Plant & $\mathrm{U}$ & $\begin{array}{l}\text { Onsite soil, groundwater, and air/chemical contamination. } \\
\text { Field work has been completed for all } 12 \text { RFIs. Six final RFI reports, } 2 \text { RFI Work } \\
\text { Plans, and } 1 \text { Interim Measures Work Plan have been approved. Two Corrective } \\
\text { Measures Studies have been submitted. One IRA and } 1 \text { final remediation have been } \\
\text { completed, and } 2 \text { interim remediations are in progress during FY } 95 \text {. }\end{array}$ \\
\hline & $\begin{array}{l}\text { St. Louis Site (St. Louis Airport } \\
\text { Site and Vicinity Properties, and } \\
\text { St. Louis Downtown Site, Latty } \\
\text { Avenue Properties) }\end{array}$ & $\mathrm{NA}^{4}$ & $\begin{array}{l}\text { Onsite soil and groundwater/primarily radioactive with limited chemical } \\
\text { contamination; offsite soil and sediments/radioactive contamination. } \\
\text { Approval of the FS has been delayed and the ROD has been deferred. Remedial } \\
\text { actions are expected to accommodate the stakeholder recommendations. }\end{array}$ \\
\hline & $\begin{array}{l}\text { Weldon Spring Site Remedial } \\
\text { Action Project }\end{array}$ & $\mathrm{F}$ & $\begin{array}{l}\text { Onsite and offsite soil and groundwater/chemical and radioactive contamination. } \\
\text { The site completed the design and initiated testing of the Pilot Sludge Processing } \\
\text { facility. Approximately } 96 \% \text { of the total anticipated volume has been excavated for } \\
\text { the Quarry Bulk Waste Removal effort as of September } 1995 \text {. }\end{array}$ \\
\hline \multirow[t]{2}{*}{ Montana } & $\begin{array}{l}\text { Western Environmental } \\
\text { Technology Office (WETO) } \\
\text { (formerly Component } \\
\text { Development and Integration } \\
\text { Facility) }\end{array}$ & $\mathrm{N}$ & $\begin{array}{l}\text { No environmental problems have been identified to date, based on site characterization } \\
\text { studies. } \\
\text { Some minor soil contamination was cleaned as part of the coal-fired } \\
\text { magnetohydrodynamics program closeout at the site. }\end{array}$ \\
\hline & $\begin{array}{l}\text { Hot Springs Substation TLM } \\
\text { Complex (BPA) }\end{array}$ & $N$ & $\begin{array}{l}\text { Soil and groundwater chemical contamination. } \\
\text { The site was characterized as Site Evaluation Accomplished in FY } 94 \text {. }\end{array}$ \\
\hline
\end{tabular}


Table I-1. Status of All DOE Facilities/Sites Subject to Section 120 of CERCLA' (Continued)

\begin{tabular}{|c|c|c|c|}
\hline STATE & DOE FACILITY & $\begin{array}{l}\text { DOCKET } \\
\text { STATUS }\end{array}$ & TYPE OF CONTAMINATION/STATUS OF REMEDIATION \\
\hline Nebraska & Sihsc Foundry Site (WAPA) & $\mathrm{U}$ & $\begin{array}{l}\text { Suspected lead contamination. } \\
\text { The PA/SI has been completed. The site has been given "non-time-critical removal } \\
\text { action" status by EPA Region VIII. A Draft Engineering Evaluation/Cost Analysis } \\
\text { (EE/CA) was submitted to the EPA in February } 1994 \text { for comment. A Removal } \\
\text { Action Memorandum was signed in August 1994. Demolition of the foundry was } \\
\text { completed in February } 1995 \text {. }\end{array}$ \\
\hline \multirow[t]{3}{*}{ Nevada } & Nevada Test Site & $\mathrm{U}$ & $\begin{array}{l}\text { Onsite soil and groundwater/radioactive contamination. } \\
\text { The Environmental Restoration Sites Inventory was initiated. Progress continued on } \\
\text { the Underground Test Area Operable Unit. Negotiation continued on a Federal } \\
\text { Facility Agreement (FFA) with the state. One RCRA Closure and } 1 \text { decommissioning } \\
\text { have been completed. Interim actions on } 8 \text { underground storage tanks and } \\
10 \text { abandoned septic tanks have been completed. Four assessments have been } \\
\text { completed. }\end{array}$ \\
\hline & Tonopah Test Range & $\mathrm{N}^{5}$ & $\begin{array}{l}\text { Soil contamination from petroleum hydrocarbons and RCRA constituents; ordnance, } \\
\text { scattered depleted uranium, surface soil plutonium contamination. } \\
\\
\text { The site was classified prior to FY } 93 \text { as Site Evaluation Accomplished. Several } \\
\text { removal actions were completed in FY } 95 \text {, and additional removal actions are planned } \\
\text { for FY } 96 \text {. The ongoing cleanup of the ordnance disposal sites, waste oil tanks, and } \\
\text { buried depleted uranium sites is being done under the RCRA authority/oversight of the } \\
\text { State of Nevada, Division of Environmental Protection. All DOE cleanups at the site } \\
\text { are expected to be covered by a pending Federal facilities agreement and consent order } \\
\text { between DOE and the State of Nevada. }\end{array}$ \\
\hline & Yucca Mountain Site & $\mathrm{U}$ & $\begin{array}{l}\text { None known. } \\
\text { A PA is to be prepared. }\end{array}$ \\
\hline
\end{tabular}


Table I-1. Status of All DOE Facilities/Sites Subject to Section 120 of CERCLA' (Continued)

\begin{tabular}{|c|c|c|c|}
\hline STATE & DOE FACILITY & $\begin{array}{l}\text { DOCKET } \\
\text { STATUS }\end{array}$ & TYPE OF CONTAMINATION/STATUS OF REMEDIATION \\
\hline \multirow[t]{5}{*}{ New Jersey } & Maywood Site & $\mathrm{F}$ & $\begin{array}{l}\text { Onsite and offsite soil/radioactive and potential chemical contamination; approximately } \\
54 \text { vicinity properties radioactively contaminated; groundwater contamination beneath } \\
\text { the pile; offsite sources. } \\
\text { EPA Region II comments on the Proposed Plan (PP) were received in September } \\
1995 \text {. Remedial action is underway for the Maywood Interim Storage Site pile. } \\
\text { Ongoing remedial actions continue at the vicinity properties. }\end{array}$ \\
\hline & Middlesex Sampling Plant & $\mathrm{U}$ & $\begin{array}{l}\text { Onsite soil/radioactive contamination. } \\
\text { The Draft Site Treatment Plans and the Characterization Report were issued. }\end{array}$ \\
\hline & New Brunswick Laboratory & $\mathrm{N}$ & $\begin{array}{l}\text { Onsite soil/radioactive contamination. } \\
\text { RA planning documents have been issued. }\end{array}$ \\
\hline & $\begin{array}{l}\text { Princeton Plasma Physics } \\
\text { Laboratory }\end{array}$ & $\mathrm{U}$ & $\begin{array}{l}\text { Onsite groundwater. } \\
\text { Negotiations are underway with the State to determine the remedial actions needed to } \\
\text { close out the site. }\end{array}$ \\
\hline & Wayne Site & $\mathrm{F}$ & $\begin{array}{l}\text { Onsite soil/radioactive and potential chemical contamination; groundwater } \\
\text { contamination beneath pile; potential offsite sources. } \\
\text { A PP has been developed and comments were received from EPA Region II. Cleanup } \\
\text { has been completed on all remaining vicinity properties. Remedial action has been } \\
\text { initiated on the interim storage pile. }\end{array}$ \\
\hline New Mexico & Gasbuggy & $\mathrm{N}$ & $\begin{array}{l}\text { Casing of the main monitoring well defective. } \\
\text { The site was included in the Nevada Test Site Phase I Report and is expected to be } \\
\text { subject to the new Hazard Ranking System scoring. }\end{array}$ \\
\hline
\end{tabular}


Table 1-1. Status of All DOE Facilities/Sites Subject to Section 120 of CERCLA' (Continued)

\begin{tabular}{|c|c|c|c|}
\hline STATE & DOE FACILITY & $\begin{array}{l}\text { DOCKET } \\
\text { STATUS }\end{array}$ & TYPE OF CONTAMINATION/STATUS OF REMEDIATION \\
\hline \multirow[t]{6}{*}{$\begin{array}{l}\text { New Mexico } \\
\text { (Continued) }\end{array}$} & Gnome-Coach & $\mathbf{U}$ & $\begin{array}{l}\text { Groundwater contamination/radioactive contamination. } \\
\text { The site was included in the Nevada Test Site Phase I Report and is expected to be } \\
\text { subject to the new Hazard Ranking System scoring. }\end{array}$ \\
\hline & Los Alamos National Laboratory & $\mathrm{U}$ & $\begin{array}{l}\text { Onsite soil/chemical and radioactive contamination. } \\
\text { An RFI and the remedial action work are in progress. The decommissioning of } \\
\text { TA-21 Buildings } 3 \text { and } 4 \text { is ongoing. }\end{array}$ \\
\hline & $\begin{array}{l}\text { Lovelace Inhalation Toxicology } \\
\text { Research Institute }\end{array}$ & $\mathrm{N}$ & $\begin{array}{l}\text { Onsite soil/chemical and radioactive contamination; groundwater/chemical } \\
\text { contamination. } \\
\text { This site was classified prior to FY } 93 \text { as Site Evaluation Accomplished. One } \\
\text { radioactive site cleanup was completed in FY } 95 \text {. One radioactive site is scheduled } \\
\text { for completion in early FY } 96 .\end{array}$ \\
\hline & Ross Aviation, Inc. & $\mathrm{U}$ & $\begin{array}{l}\text { Onsite soil/chemical contamination. } \\
\text { A PA was due June 12, 1993. Contaminated soil was removed, and clean soil was } \\
\text { placed in the area in FY } 92 . \text { The CERCLA site contamination is considered closed. }\end{array}$ \\
\hline & $\begin{array}{l}\text { Sandia National } \\
\text { Laboratories/New Mexico }\end{array}$ & $\mathrm{U}$ & $\begin{array}{l}\text { Onsite soil and groundwater/chemical and radioactive contamination. } \\
\text { The Site-wide Hydrogeologic Characterization Project Annual Report was completed. } \\
\text { Four RFI work plans were completed. } 34 \text { voluntary corrective measures were } \\
\text { completed. }\end{array}$ \\
\hline & Waste Isolation Pilot Plant & $\mathrm{U}^{5}$ & $\begin{array}{l}\text { None known. } \\
\text { The Compliance Status Report (191) was submitted to the EPA in March 1994. A PA } \\
\text { was submitted in August 1994. A Draft Compliance Application was submitted to the } \\
\text { EPA on schedule in March 1995. The final Compliance Certification Application to } \\
\text { the EPA relative to the Disposal Decision Plan has been accelerated by } 2 \text { months; it is } \\
\text { now due to be submitted in October 1996. }\end{array}$ \\
\hline
\end{tabular}


Table I-1. Status of All DOE Facilities/Sites Subject to Section 120 of CERCLA ${ }^{1}$ (Continued)

\begin{tabular}{|c|c|c|c|}
\hline STATE & DOE FACILITY & $\begin{array}{l}\text { DOCKET } \\
\text { STATUS }\end{array}$ & TYPE OF CONTAMINATION/STATUS OF REMEDIATION \\
\hline \multirow[t]{5}{*}{ New York } & Brookhaven National Laboratory & F & $\begin{array}{l}\text { Groundwater and soil/chemical and radioactive contamination. } \\
\text { The OU I Remedial Investigation/Remedial Action (RI/RA) was submitted in } \\
\text { September 1995. The OU II/VIII RI/FS work plan was submitted in December } 1994 . \\
\text { The OU IV FS/Draft PP was submitted in December 1994, and the draft ROD was } \\
\text { submitted in May 1995. }\end{array}$ \\
\hline & Colonie Site & $\mathrm{N}$ & $\begin{array}{l}\text { Onsite soil and building contamination. } \\
\text { An EE/CA for a site building was approved in May } 1993 \text {. The site is currently } \\
\text { formulating a site wide EE/CA for radioactive wastes. }\end{array}$ \\
\hline & $\begin{array}{l}\text { Knolls Atomic Power } \\
\text { Laboratory, Niskayuna and West } \\
\text { Milton Sites }\end{array}$ & $\mathrm{N}$ & $\begin{array}{l}\text { Minor soil and groundwater contamination/chemical and radioactive contamination at } \\
\text { both sites. } \\
\text { Both sites were classified as Site Evaluation Accomplished in FY } 94 \text {. }\end{array}$ \\
\hline & Niagara Falls Storage Site & $\mathrm{N}$ & $\begin{array}{l}\text { Former radioactive contamination. } \\
\text { Site remediation was completed in } 1986 \text {. The DOE/EPA/State are working toward } \\
\text { applicable long-term management criteria for onsite radioactive residues. Radioactive } \\
\text { wastes were disposed of in an onsite disposal cell. }\end{array}$ \\
\hline & $\begin{array}{l}\text { West Valley Demonstration } \\
\text { Project }^{6}\end{array}$ & $\mathrm{NA}^{7}$ & $\begin{array}{l}\text { Onsite radioactive contamination. } \\
\text { A PA was submitted to EPA Region II in October 1993. The site is being } \\
\text { investigated pursuant to a RCRA 3008(h) Administrative Order of Consent signed by } \\
\text { EPA Region II and the New York State Department of Environmental Conservation. }\end{array}$ \\
\hline
\end{tabular}


Table I-1. Status of All DOE Facilities/Sites Subject to Section 120 of CERCLA' (Continued)

\begin{tabular}{|c|c|c|c|}
\hline STATE & DOE FACILITY & $\begin{array}{l}\text { DOCKET } \\
\text { STATUS }\end{array}$ & TYPE OF CONTAMINATION/STATUS OF REMEDIATION \\
\hline \multirow[t]{3}{*}{ Ohio } & $\begin{array}{l}\text { Fernald Environmental } \\
\text { Management Project (formerly } \\
\text { Feed Materials Production } \\
\text { Center) }\end{array}$ & F & $\begin{array}{l}\text { Onsite and offsite soil and groundwater/radioactive contamination. } \\
\text { Three removal actions were completed and } 8 \text { are ongoing. The draft ROD for OU } 1 \\
\text { was submitted on November 1994, and the Final ROD was signed in March } 1995 . \\
\text { The OU } 1 \text { Draft Remedial Design Work Plan (RDWP) was submitted in April } 1995 \\
\text { and approved in June 1995. The OU } 2 \text { RI report was approved in January } 1995 \text {. The } \\
\text { OU } 2 \text { FS/PP was approved in January 1995. The OU } 2 \text { Draft ROD was submitted in } \\
\text { February } 1995 \text { and approved in June 1995, and the OU } 2 \text { RDWP was submitted in } \\
\text { August } 1995 \text {. The OU } 3 \text { Interim RD/RA Work Plan was submitted March } 1995 \text { and } \\
\text { approved May 1995, the OU } 3 \text { Draft RI/FS/PP was submitted in September } 1995 \text {. } \\
\text { The OU } 4 \text { Final ROD was signed in December 1994, and the OU 4 Final RDWP was } \\
\text { approved in June 1995. The OU } 5 \text { RI report was submitted in June 1994 and } \\
\text { approved in February 1995. The OU } 5 \text { draft FS/PP was submitted in November } 1994 \\
\text { and approved in April 1995, and the OU } 5 \text { draft ROD was submitted in August } 1995 .\end{array}$ \\
\hline & Mound Plant & $\mathrm{F}$ & $\begin{array}{l}\text { Onsite and offsite soil/radioactive contamination; onsite and offsite } \\
\text { groundwater/chemical and tritium contamination. } \\
\text { The OU } 1 \text { ROD was completed. Design of the Miami-Erie Canal removal was } \\
\text { initiated. A } 30 \text {-acre parcel of land was declared clean for other uses. Seven removal } \\
\text { actions have been completed. }\end{array}$ \\
\hline & $\begin{array}{l}\text { Portsmouth } \\
\text { Uranium Enrichment Complex }{ }^{3}\end{array}$ & $\mathrm{U}$ & $\begin{array}{l}\text { Onsite soil and ground-water/chemical and radioactive contamination. } \\
\text { No CERCLA activities were conducted during FY 95. Portsmouth is currently } \\
\text { involved with RCRA corrective action activities. }\end{array}$ \\
\hline Oklahoma & $\begin{array}{l}\text { National Institute for Petroleum } \\
\text { and Energy Research }\end{array}$ & $\mathrm{U}$ & $\begin{array}{l}\text { Onsite soil/chemical contamination. } \\
\text { The site submitted a PA on August 10,1994. The Hazard Ranking Score was below } \\
\text { 28.5(14); thus, no further actions are planned. EPA has not responded to the PA. }\end{array}$ \\
\hline
\end{tabular}


Table I-1. Status of All DOE Facilities/Sites Subject to Section 120 of CERCLA' (Continued)

\begin{tabular}{|c|c|c|c|}
\hline STATE & DOE FACILITY & $\begin{array}{l}\text { DOCKET } \\
\text { STATUS }\end{array}$ & TYPE OF CONTAMINATION/STATUS OF REMEDIATION \\
\hline \multirow[t]{6}{*}{ Oregon } & $\begin{array}{l}\text { Alvey Maintenance Headquarters } \\
\text { (BPA) }\end{array}$ & $N$ & $\begin{array}{l}\text { Onsite soil/chemical contamination. } \\
\text { The site was characterized as Site Evaluation Accomplished. }\end{array}$ \\
\hline & Bake Oven Substation (BPA) & U & $\begin{array}{l}\text { Potential PCB contamination. } \\
\text { PCB cleanup has been completed. The final draft report was sent to EPA Region X. } \\
\text { A Memorandum of Agreement (MOA) was completed in August } 1994 \text {. }\end{array}$ \\
\hline & Celilo Converter Station (BPA) & $\mathrm{U}$ & $\begin{array}{l}\text { Onsite soil/chemical contamination. } \\
\text { A PA was submitted in FY } 95 \text {. }\end{array}$ \\
\hline & Lapine (BPA) & $\mathrm{NA}^{7}$ & $\begin{array}{l}\text { Onsite soil/chemical contamination. } \\
\text { The site was deleted from the docket during FY } 95 \text {. }\end{array}$ \\
\hline & Ostrander Substation (BPA) ${ }^{8}$ & $N$ & $\begin{array}{l}\text { Onsite chemical contamination, no contamination of media. } \\
\text { A PA was submitted to EPA Region X in October 1993. The site was characterized } \\
\text { as Site Evaluation Accomplished in FY } 94 .\end{array}$ \\
\hline & Troutdale Substation (BPA) & $\mathrm{N}$ & $\begin{array}{l}\text { Onsite soil/chemical contamination. } \\
\text { The site was characterized as Site Evaluation Accomplished. }\end{array}$ \\
\hline Pennsylvania & $\begin{array}{l}\text { Bettis Atomic Power Laboratory, } \\
\text { West Mifflin }\end{array}$ & $N$ & $\begin{array}{l}\text { Minor soil and groundwater contamination/chemical and radioactive contamination. } \\
\text { This site was characterized as Site Evaluation Accomplished in FY 90. No further } \\
\text { EPA action is required. }\end{array}$ \\
\hline
\end{tabular}


Table I-1. Status of All DOE Facilities/Sites Subject to Section 120 of CERCLA' (Continued)

\begin{tabular}{|c|c|c|c|}
\hline STATE & DOE FACILITY & $\begin{array}{l}\text { DOCKET } \\
\text { STATUS }\end{array}$ & TYPE OF CONTAMINATION/STATUS OF REMEDIATION \\
\hline $\begin{array}{l}\text { Pennsylvania } \\
\text { (Continued) }\end{array}$ & $\begin{array}{l}\text { Pittsburgh Energy Technology } \\
\text { Center }^{9}\end{array}$ & $\mathrm{U}$ & $\begin{array}{l}\text { Onsite soil and groundwater contamination. } \\
\text { The first round of groundwater monitoring is nearing completion. Data validation is } \\
\text { ongoing. A Health and Ecological Risk Assessment is in progress. The baseline } \\
\text { assessment of the old synthane area is complete. The site is awaiting funding for } \\
\text { remediation actions. }\end{array}$ \\
\hline Puerto Rico & $\begin{array}{l}\text { Center for Energy and } \\
\text { Environmental Research }\end{array}$ & $\mathrm{N}$ & $\begin{array}{l}\text { Onsite soil/radioactive contamination. } \\
\text { A PA was submitted on May } 16,1988 \text {. The decommissioning activities are complete. }\end{array}$ \\
\hline South Carolina & Savannah River Site & $\mathrm{F}$ & $\begin{array}{l}\text { Onsite groundwater, soil and air/chemical and radioactive contamination. } \\
\text { Fifteen RCRA Facility Investigation/Remedial Investigation (RFI/RI) Plans, } 24 \text { Site } \\
\text { Evaluation Reports, } 2 \text { Corrective Measures Studies/FS Reports, } 13 \mathrm{RFI} / \mathrm{RI} \text { and } \\
\text { Baseline Risk Assessment Reports, and } 3 \mathrm{RD} / \mathrm{RA} \text { Work Plans were submitted. Five } \\
\text { RAs and } 15 \text { Interim Removal Actions were completed. Four RODs were signed. } \\
\text { Field characterization sampling has been conducted, and the data analysis has begun at } \\
38 \text { waste sites. }\end{array}$ \\
\hline South Dakota & $\begin{array}{l}\text { Watertown Maintenance Facility } \\
\text { (WAPA) }\end{array}$ & $N$ & $\begin{array}{l}\text { Onsite potential soil/chemical contamination. } \\
\text { A PA was submitted in May 1990, and an SI was submitted in October 1991. The } \\
\text { site is awaiting a response from EPA Region VIII. The site was characterized as Site } \\
\text { Evaluation Accomplished in October 1994. }\end{array}$ \\
\hline Tennessee & $\begin{array}{l}\text { Oak Ridge Reservation: } \\
\text { K-25 Site (Oak Ridge } \\
\text { Gaseous Diffusion } \\
\text { Plant) } \\
\text { Oak Ridge Associated } \\
\text { Universities }\end{array}$ & $\mathrm{F}$ & $\begin{array}{l}\text { Onsite groundwater, soil and surface water/ chemical and radioactive contamination. } \\
\text { Three closures were completed as remedial actions. Two Interim Actions and two } \\
\text { decommissionings involving eight structures were completed. Two RCRA Closure } \\
\text { Plans and one Site Development Plan were submitted. } \\
\text { Onsite groundwater, soil and surface water/chemical and radioactive contamination. } \\
\text { The South Campus Facility RI/FS and PP were submitted and approved in FY } 95 \text {. }\end{array}$ \\
\hline
\end{tabular}


Table I-1. Status of All DOE Facilities/Sites Subject to Section 120 of CERCLA' (Continued)

\begin{tabular}{|c|c|c|c|}
\hline STATE & DOE FACILITY & $\begin{array}{l}\text { DOCKET } \\
\text { STATUS }\end{array}$ & TYPE OF CONTAMINATION/STATUS OF REMEDIATION \\
\hline $\begin{array}{l}\text { Tennessee } \\
\text { (Continued) }\end{array}$ & $\begin{array}{l}\text { Oak Ridge Associated } \\
\text { Universities (Continued): } \\
\text { Oak Ridge National } \\
\text { Laboratory } \\
\text { Y-12 Plant } \\
\text { Offsite }\end{array}$ & $\mathrm{F}$ & $\begin{array}{l}\text { Onsite groundwater, soil, and surface water/chemical and radioactive contamination. } \\
\text { One RI, one RI/FS, three remedial actions, and three interim actions were completed. } \\
\text { Two assessments are in progress. } \\
\text { Onsite groundwater, soil, and surface water/chemical and radioactive contamination. } \\
\text { Two PPs, } 2 \text { closures, one decommissioning, one removal, and one interim action were } \\
\text { completed. } \\
\text { Offsite soil and surface water/chemical and radioactive contamination, mercury and } \\
\text { other heavy metals, PCBs, and traces of uranium in floodplain, soils, and sediment. } \\
\text { Two PPs and } 2 \text { RODs were approved, and construction of } 2 \text { remedial actions has been } \\
\text { initiated. }\end{array}$ \\
\hline \multirow[t]{2}{*}{ Texas } & Big Hill Site (SPRO) & $\mathrm{U}$ & $\begin{array}{l}\text { Onsite soil/chemical contamination. } \\
\text { A determination was made by EPA Region VI on September 16, } 1991 \text { that no PA/SI } \\
\text { was required. }\end{array}$ \\
\hline & Pantex Plant & F & $\begin{array}{l}\text { Onsite soil and groundwater/chemical and radioactive contamination. } \\
\text { The FFA is under negotiation. Sixty-one Solid Waste Management Units (SWMUs) } \\
\text { were closed in FY } 95 \text { as No Further Action Required, and } 5 \text { removal actions were } \\
\text { completed. }\end{array}$ \\
\hline
\end{tabular}


Table I-1. Status of All DOE Facilities/Sites Subject to Section 120 of CERCLA' (Continued)

\begin{tabular}{|c|c|c|c|}
\hline STATE & DOE FACILITY & $\begin{array}{l}\text { DOCKET } \\
\text { STATUS }\end{array}$ & TYPE OF CONTAMINATION/STATUS OF REMEDIATION \\
\hline \multirow[t]{2}{*}{ Utah } & Monticello Mill Site & $\mathrm{F}$ & $\begin{array}{l}\text { Onsite and offsite groundwater, soil and surface water/chemical and radioactive } \\
\text { contamination. } \\
\text { Remedial design and remedial action are continuing at the Mill Site. Offsite drainage } \\
\text { control ditches and the liner for Pond } 3 \text { have been completed. Wastewater treatment } \\
\text { plant has been installed, tested, and operated to treat contaminated runoff. Millsite } \\
\text { Remediation design (includes onsite repository) was completed, and a subcontract for } \\
\text { the Millsite Remediation was awarded. Unnecessary groundwater monitoring wells } \\
\text { were abandoned at the repository site. The remedial action was started at three } \\
\text { peripheral properties and completed at one. The Draft Final OU } 3 \mathrm{RI} / \mathrm{FS} \text { Work Plan, } \\
\text { Field Sampling Plan, and Quality Assurance Project Plan were submitted for } \\
\text { regulatory review. Soil, sediment, surface water, groundwater, and biota sampling for } \\
\text { the RI were completed. }\end{array}$ \\
\hline & Monticello Vicinity Properties & $\mathrm{NA}^{4}$ & $\begin{array}{l}\text { Onsite and offsite groundwater, soil, and surface water/chemical and radioactive } \\
\text { contamination. } \\
\text { Remedial actions were completed on } 81 \text { more of the } 411 \text { Vicinity Properties in FY } 95 \\
\text { (375 total). Remedial design and remedial action for other Monticello Vicinity } \\
\text { Properties are continuing. }\end{array}$ \\
\hline \multirow[t]{3}{*}{ Washington } & $\begin{array}{l}\text { Columbia Basin Project AEC } \\
\text { Zone 2,4-D Site }\end{array}$ & U & $\begin{array}{l}\text { Onsite soil/chemical contamination. } \\
\text { Deletion from the docket was requested for this site. }\end{array}$ \\
\hline & Columbia Substation (BPA) & $\mathrm{N}$ & $\begin{array}{l}\text { Onsite soil/chemical contamination. } \\
\text { The site was characterized as Site Evaluation Accomplished. }\end{array}$ \\
\hline & Cosmopolis (BPA) & $\mathrm{NA}^{7}$ & $\begin{array}{l}\text { Potential PCB contamination. } \\
\text { This site was deleted from the docket on April 11, } 1995 .\end{array}$ \\
\hline
\end{tabular}


Table I-1. Status of All DOE Facilities/Sites Subject to Section 120 of CERCLA' (Continued)

\begin{tabular}{|c|c|c|c|}
\hline STATE & DOE FACILITY & $\begin{array}{l}\text { DOCKET } \\
\text { STATUS }\end{array}$ & TYPE OF CONTAMINATION/STATUS OF REMEDIATION \\
\hline \multirow[t]{8}{*}{$\begin{array}{l}\text { Washington } \\
\text { (Continued) }\end{array}$} & Covington Substation (BPA) & $\mathrm{U}$ & $\begin{array}{l}\text { Onsite soil/chemical contamination. } \\
\text { An Addendum to the SI is in process. }\end{array}$ \\
\hline & $\begin{array}{l}\text { G.H. Bell Substation and } \\
\text { Maintenance Complex (BPA) }\end{array}$ & $\mathrm{N}$ & $\begin{array}{l}\text { Onsite soil/chemical contamination. } \\
\text { The site has been characterized as Site Evaluation Accomplished. }\end{array}$ \\
\hline & Hanford Site - Area 100 & F & $\begin{array}{l}\text { Onsite groundwater and soil/chemical and radioactive contamination. } \\
\text { Eight proposed plans and } 9 \text { Focused FS Reports were submitted. One ROD was } \\
\text { issued, and one treatability test has been completed. }\end{array}$ \\
\hline & Hanford Site - Area 200 & $\mathrm{~F}$ & $\begin{array}{l}\text { Onsite groundwater and soil/chemical and radioactive contamination. } \\
\text { One PP, one Focused FS Report, and one Limited Fuel Investigation Report were } \\
\text { submitted. Two RODs were issued. Three treatability test were completed. }\end{array}$ \\
\hline & Hanford Site - Area 300 & $\mathrm{~F}$ & $\begin{array}{l}\text { Onsite groundwater and soil/chemical and radioactive contamination. } \\
\text { One Phase Three FS report, one Phase Two RI Report, and one Limited Field } \\
\text { Investigation Report were submitted. }\end{array}$ \\
\hline & Hanford Site - Area 1100 & F & $\begin{array}{l}\text { Onsite groundwater and soil/chemical and radioactive contamination. } \\
\text { Cleanup of the area was completed in FY } 95 .\end{array}$ \\
\hline & Maple Valley Substation (BPA) & $\mathrm{NA}^{7}$ & $\begin{array}{l}\text { Onsite soil/chemical contamination. } \\
\text { This site was deleted from the docket on April 11, } 1995 .\end{array}$ \\
\hline & Midway Substation (BPA) & $N$ & $\begin{array}{l}\text { Onsite soil/chemical contamination. } \\
\text { This site has been characterized as Site Evaluation Accomplished. }\end{array}$ \\
\hline
\end{tabular}


Table I-1. Status of All DOE Facilities/Sites Subject to Section 120 of CERCLA' (Continued)

\begin{tabular}{|c|c|c|c|}
\hline STATE & DOE FACILITY & $\begin{array}{l}\text { DOCKET } \\
\text { STATUS }\end{array}$ & TYPE OF CONTAMINATION/STATUS OF REMEDIATION \\
\hline \multirow[t]{6}{*}{$\begin{array}{l}\text { Washington } \\
\text { (Continued) }\end{array}$} & Monroe (BPA) & $\mathrm{NA}^{7}$ & $\begin{array}{l}\text { Onsite chemical contamination. } \\
\text { This site was deleted from the docket on April 11, } 1995 .\end{array}$ \\
\hline & Olympia Substation (BPA) & $\mathrm{N}$ & $\begin{array}{l}\text { Onsite soil/chemical contamination. } \\
\text { This site was characterized as Site Evaluation Accomplished in FY } 94 .\end{array}$ \\
\hline & Port Angeles (BPA) & $N$ & $\begin{array}{l}\text { Onsite chemical contamination. } \\
\text { This site was characterized as Site Evaluation Accomplished in FY } 95 .\end{array}$ \\
\hline & Ross Complex (BPA) & $\mathrm{F}$ & $\begin{array}{l}\text { Onsite soil and potential groundwater/chemical contamination. } \\
\text { All remediation activities and associated reports were either completed in FY } 95 \text { or are } \\
\text { expected to be completed early in FY } 96 \text {. DOE plans to initiate activities to delete the } \\
\text { site from the NPL in FY } 96 .\end{array}$ \\
\hline & Snohomish Substation (BPA) & $\mathrm{N}$ & $\begin{array}{l}\text { Onsite soil/chemical contamination. } \\
\text { This site was characterized as Site Evaluation Accomplished in FY } 94 .\end{array}$ \\
\hline & Snow King Substation (BPA) & $\mathrm{NA}^{7}$ & $\begin{array}{l}\text { No information. } \\
\text { This site was deleted from the docket on April 11, } 1995 .\end{array}$ \\
\hline West Virginia & $\begin{array}{l}\text { Morgantown Energy Technology } \\
\text { Center }\end{array}$ & $N$ & $\begin{array}{l}\text { Onsite soil and potential groundwater/chemical contamination. } \\
\text { The PA/SI is under review by EPA Region III. A detailed information packet will be } \\
\text { provided in May } 1996 \text { in response to an EPA Deficiency Checklist, and a request for } \\
\text { additional data is under preparation for the HRS scoring. }\end{array}$ \\
\hline Wyoming & Casper Field Branch (WAPA) & $\mathrm{N}$ & $\begin{array}{l}\text { None known. } \\
\text { This site has been characterized as Site Evaluation Accomplished. }\end{array}$ \\
\hline
\end{tabular}


Table I-1. Status of All DOE Facilities/Sites Subject to Section 120 of CERCLA' (Continued)

\begin{tabular}{|l|l|c|l|}
\hline \hline \multicolumn{1}{|c|}{ STATE } & DOE FACILITY & $\begin{array}{l}\text { DOCKET } \\
\text { STATUS }\end{array}$ & \multicolumn{1}{|c|}{ TYPE OF CONTAMINATION/STATUS OF REMEDIATION } \\
\hline $\begin{array}{l}\text { Wyoming } \\
\text { (Continued) }\end{array}$ & Hoe Creek & $\mathrm{N}$ & $\begin{array}{l}\text { Onsite groundwater/chemical contamination. } \\
\text { Report on a one acre demonstration of a recommended cleanup technology } \\
\text { (biosparging) is expected to be completed by June 1996. The final cleanup technology } \\
\text { and schedule appended to the Wyoming Agreement is expected to be complete in } \\
\text { early FY 97. }\end{array}$ \\
\cline { 2 - 4 } & Rock Springs Oil Shale Retort & $\mathrm{N}^{2}$ & $\begin{array}{l}\text { Onsite groundwater/chemical contamination. } \\
\text { A report on the cleanup alternatives study is expected to be completed by } \\
\text { January 1996. A demonstration of the recommended alternative is expected to begin } \\
\text { in April 1996. The final cleanup technology and schedule appended to the Wyoming } \\
\text { Agreement is expected to be complete in early FY 97. }\end{array}$ \\
\hline
\end{tabular}

Acronyms and abbreviations used in this table are found in Appendix A.

2 The site was added to the docket on April 11, 1995.

3 The April 11, 1995 docket added the U.S. Enrichment Corporation, located in Piketon, Ohio. The DOE sites at which the U.S. Enrichment Corporation generates hazardous waste as a site operator are the Paducah Gaseous Diffusion Plant in Kentucky and the Portsmouth Uranium Enrichment Complex in Ohio. Refer to Section I.C., "Overview of DOE Facilities Subject to CERCLA Section 120," for more details.

4 The St. Louis Site and the Monticello Vicinity Properties are privately owned facilities and are not listed on the docket; they are on the NPL, however, and DOE is responsible for their remediation.

5 The Sandia National Laboratory/Tonopah Site in Nevada and the Carlsbad Site in New Mexico were added to the docket on April 11, 1995. EPA has been informed by DOE that these sites are already on the docket as Tonopah Test Range and Waste Isolation Pilot Plant, respectively.

6 In Docket \#9, the West Valley Demonstration Project is identified as being privately owned and not a government facility. It has been deleted from the docket. Site activities for this fiscal year are provided as a courtesy.

7 The site was deleted from the docket on April 11, 1995.

$8 \quad$ This site is listed on the docket as "Oregon City (BPA)." EPA has been notified that the docket name is incorrect.

9 The responsible agency listed in the docket for the Pittsburgh Energy Technology Center has been changed to the Department of Labor, Mine Safety \& Health Administration. DOE believes this is an error.

Key: $\quad$ NA $=$ Not Applicable

$\mathrm{U}=$ Undetermined

$\mathrm{N}=$ Site Evaluation Accomplished

$\mathrm{F}=$ Currently Final on the NPL 


\section{SECTION II}

STATUS OF CERCLA ACTIVTTIES AT

DEPARTMENT OF ENERGY SITES

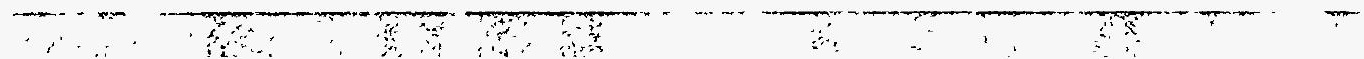




\section{DOE CERCLA COMPLIANCE STRATEGY}

\section{II.A DOE Organizations Responsible for CERCLA Compliance}

This report was prepared by DOE's Office of Environmental Restoration (EM-40) within the Office of Environmental Management (EM). EM was created in 1989 to consolidate responsibility within DOE for environmental management activities at the nuclear weapons complex sites. Additional EM functions related to environmental restoration at the nuclear weapons complex sites include 1) ensuring worker safety and health, 2) managing and planning budgets, 3) resolving legal and compliance issues, 4) implementing public participation programs, 5) safely transporting all DOE materials, and 6) minimizing waste generated.

Within the EM organization, the following offices play an important role in CERCLA compliance activities:

- The Office of Waste Management (EM-30) is responsible for the treatment, storage, and disposal of large volumes of wastes generated by environmental restoration activities.

- The Office of Environmental Restoration (EM-40) is responsible for the cleanup of contamination at DOE nuclear weapons sites and for facility decommissioning.

- The Office of Technology Development (EM-50) is responsible for the development of new and more effective technologies to address contamination and management of wastes at DOE sites.

- The Office of Nuclear Material and Facility Stabilization (EM-60) is responsible for the safe transition of facilities for decommissioning by the office of Environmental Restoration.

This report also covers CERCLA compliance activities at sites that are not in the nuclear weapons complex. Information on these sites was provided by the following DOE organizations:

- Bonneville Power Administration,

- Western Area Power Administration,

- $\quad$ Office of Energy Research,

- Morgantown Energy Technology Center, and

- Pittsburgh Energy Technology Center.

These DOE organizations are responsible for CERCLA compliance at the sites they own and operate.

DOE's Office of Policy and Assistance (EH-41) within DOE's Office of Environment, Safety and Health (EH) assists all DOE organizations with CERCLA compliance activities. The mission of the EH-41 organization is to 1) develop Department-wide environmental protection policies and complexwide strategies for protecting the public and the environment and for attaining and maintaining environmental compliance with internal and external environmental requirements, and 2) assist program and field offices in averting environmental compliance problems. In addition, EH- 41 serves as the CERCLA Docket Coordinator. The Coordinator receives the EPA's initial letter of proposed listings to the docket and NPL, and is responsible for verifying the accuracy of the proposed listings with the Program and Field Officer in a formal response to EPA. 


\section{II.B. Legal Context for DOE's Remediation Activities}

DOE's remediation activities are governed by CERCLA, RCRA, the National Environmental Policy Act (NEPA), and other applicable laws. CERCLA addresses the uncontrolled releases of substances to the environment and the cleanup of inactive waste sites. RCRA addresses the management of regulated hazardous waste and requires that permits be obtained for DOE facilities that treat, store, or dispose of hazardous or mixed waste. RCRA also requires corrective action to address releases of hazardous contaminants. NEPA requires that Federal agencies consider the environmental effects of major Federal actions significantly affecting the human environment in the decisionmaking process. It is the Department's policy to rely on the CERCLA process for review of actions to be taken under CERCLA and to incorporate, to the extent practicable, NEPA values such as analysis of cumulative, offsite, ecological, and socioeconomic impacts into CERCLA documentation. The Department may, however, after consulting with its stakeholders and as a matter of policy, integrate the CERCLA and NEPA processes for specific proposed actions. It is also part of the Department's policy to take steps to ensure opportunities for early public involvement in the CERCLA process.

\section{II.C. Environmental Contamination at DOE Facilities}

The CERCLA Annual Report encompasses the following DOE facilities:

- Facilities in the nuclear weapons complex (i.e., production facilities, laboratories, and testing facilities);

- Electrical substations and electrical substation support facilities;

- Energy research and development laboratories; and

- Facilities involved in research and testing activities associated with alternative energy technologies.

The Office of Environmental Restoration is responsible for the cleanup of facilities in the nuclear weapons complex. Figure II-1 shows the locations of DOE facilities subject to CERCLA Section 120 that are in the nuclear weapons complex.

The Bonneville Power Administration (BPA) and Western Area Power Administration (WAPA) are responsible for the DOE electrical substations and electrical substation support facilities that are subject to CERCLA Section 120. The Office of Energy Research is responsible for energy research and development laboratories subject to CERCLA 120. The Morgantown Energy Technology Center and the Pittsburgh Energy Technology Center are responsible for the DOE alternative energy technology research and development facilities that are subject to CERCLA Section 120. Figure II-2 shows the locations of DOE facilities subject to CERCLA Section 120 that are not in the nuclear weapons complex.

\section{Nuclear Weapons Complex Facilities}

The environmental contamination problems at facilities in the nuclear weapons complex are unlike those associated with other industries. They include unique radiation hazards, unprecedented volumes of contaminated water and soil, and a vast number of contaminated structures including reactors and 
chemical plants. The environmental contamination problems associated with each step in the nuclear weapons production process are briefly described below.

- Uranium mining and milling produced large volumes of mill tailings which contain toxic heavy metals and radioactive radium and thorium.

- Uranium enrichment operations caused extensive contamination of the environment with radioactive materials, solvents, polychlorinated biphenyls, heavy metals, and other toxic substances.

- Fuel and target fabrication resulted in releases of uranium dust, landfills contaminated with chemicals, and contaminated facilities.

- Reactor irradiation produced highly radioactive spent fuel and contaminated facilities.

- Chemical separations produced highly radioactive and hazardous chemical waste, as well as wastewater that contained small amounts of radionuclides and chemicals. Discharge of some of this wastewater directly to the ground caused widespread contamination. Chemical separation processes also produced contaminated facilities.

- Fabrication of weapons components produced plutonium-contaminated waste and facilities.

- Weapons assembly and maintenance resulted in soil contaminated with high-explosive waste, fuel and oil leaks, and discharge of solvents to the environment.

- $\quad$ Research, development, and testing activities resulted in highly radioactive underground craters and soils and debris contaminated with low-level waste.

In most cases, the environmental contamination caused by nuclear weapons production activities resulted from materials production and waste management practices that would be considered inadequate by today's standards. Additional information on the environmental contamination resulting from nuclear weapons production is available in the following DOE publications:

- $\quad$ Estimating the Cold War Mortgage: The 1995 Baseline Environmental Management Report, March 1995 (DOE/EM-0232); and

- $\quad$ Closing the Circle on the Splitting of the Atom: The Environmental Legacy of Nuclear Weapons Production in the United States and What the Department of Energy Is Doing About It, January 1995.

Both documents may be ordered from the Environmental Management Information Center at 1-800-7EM-DATA. The 1996 Baseline Environmental Management Report is expected to be available in the Spring of 1996.

\section{Other Facilities}

Other facilities in the DOE complex include electrical substations; facilities supporting electrical power distribution; petroleum and oil shale reserve facilities; and petroleum, coal, oil shale, and energy research facilities. Environmental contamination problems at these types of facilities are generally 


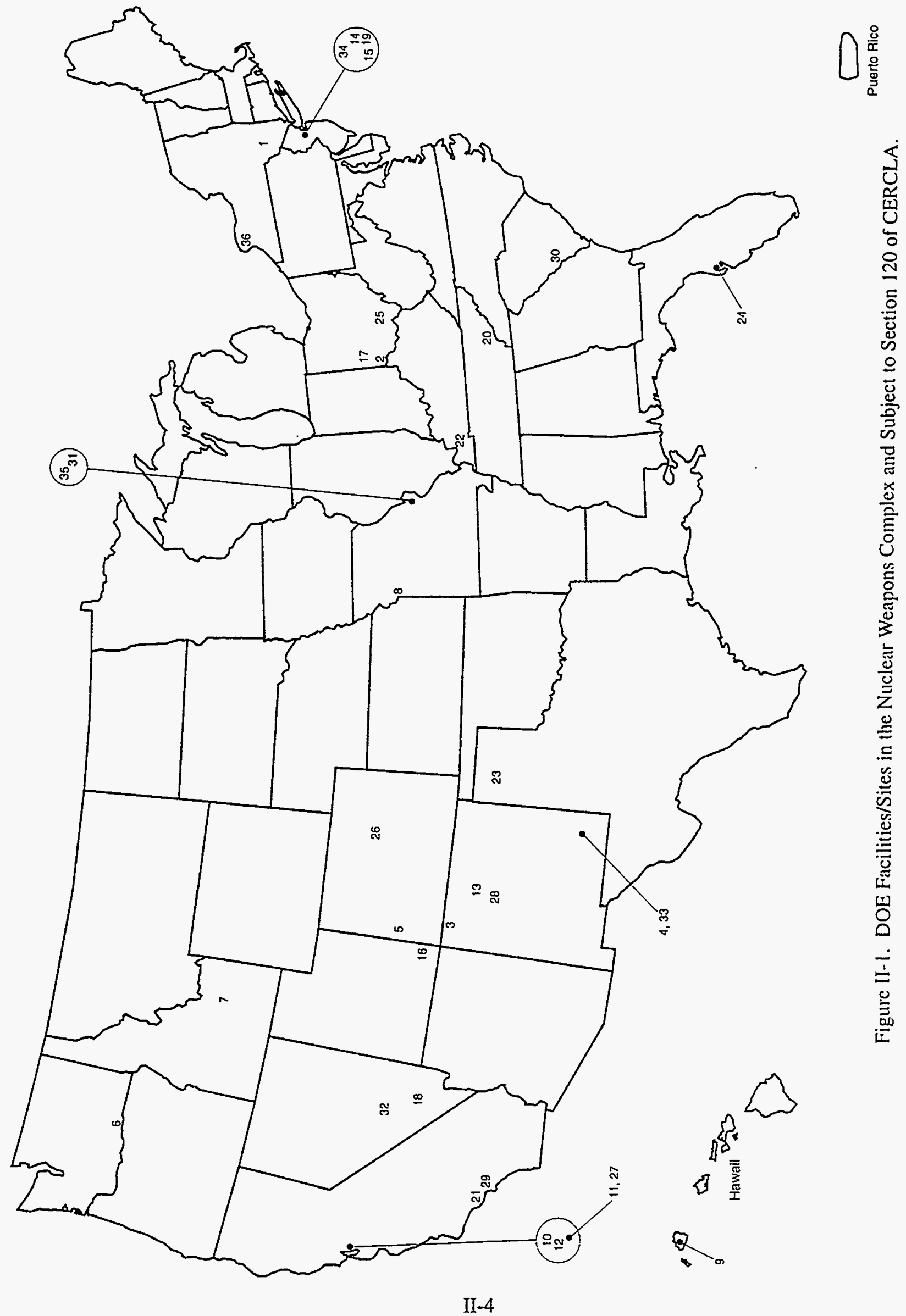




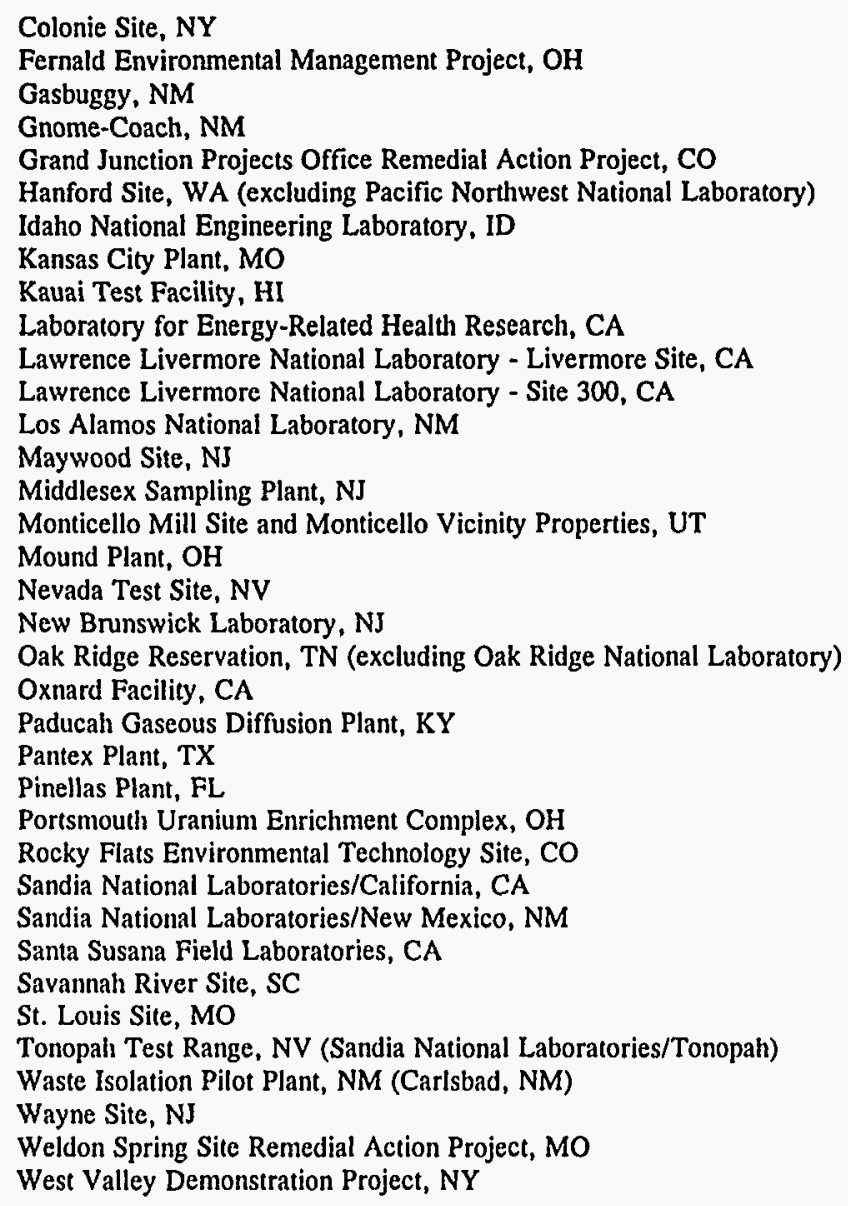

Figure II-1. DOE Facilities/Sites in the Nuclear Weapons Complex and Subject to Section 120 of CERCLA - Key (Continued). 


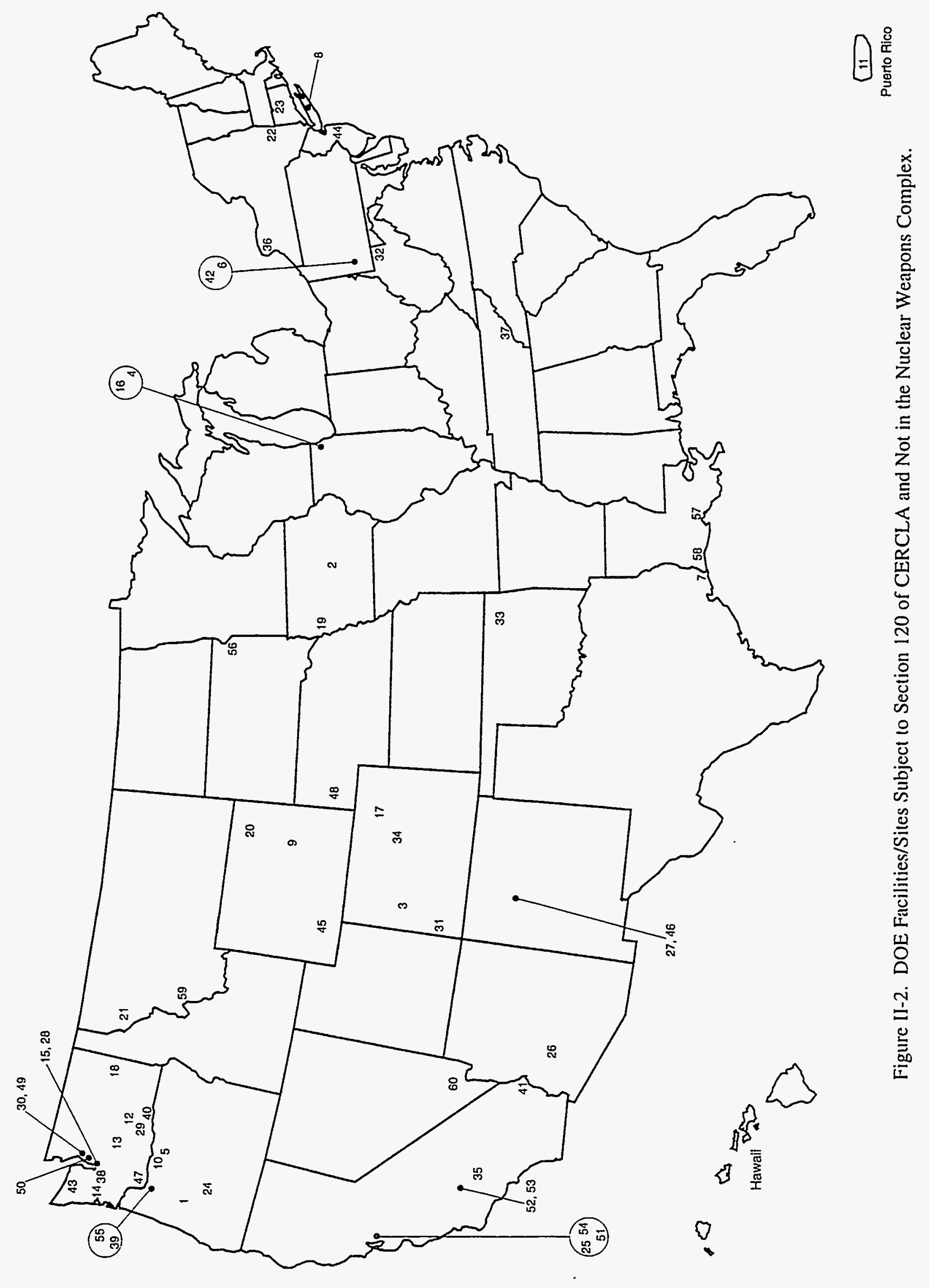


Alvey Maintenance Headquarters, $O R$

Ames Laboratory, IA

Anvil Points Facility, Naval Oil Shale Reserve No. 3, CO

Argonne National Laboratory - East, IL

Bake Oven Substation, OR

Bettis Atomic Power Laboratory, West Mifflin, PA

Big Hill Site, TX

Brookhaven National Laboratory, NY

Casper Ficld Branch, WY

10 Celilo Converter Station, OR

11 Center for Energy and Environmental Research, PR

12 Columbia Basin Project AEC Zone 2,4-D Sitc, WA

13 Columbia Substation, WA

14 Cosmopolis, WA

15 Covington Substation, WA

16 Fermi National Accelerator Laboratory, IL

17 Fort Morgan Substation, CO

18 G.H. Bell Substation and Maintenance Complex, WA

19 Hinton Hazardous Waste Storage Facility, IA

20 Hoc Creek, WY

21 Hot Springs Substation TLM Complex, MT

22 Knolls Atomic Power Laboratory, Niskayuna and West Milton Sites, NY

23 Knolls Atomic Power Laboratory, Windsor Site, CT

24 Lapine, OR

Lawrence Berkeley National Laboratory, CA

Liberty Substation, AZ

Lovelace Inhalation Toxicology Research Institute, NM

Maple Valley Substation, WA

Midway Substation, WA

Monroe, WA

Montrose Power Operations Center, $\mathrm{CO}$

Morgantown Energy Technology Center, WV

National Institute for Petroleum and Energy Research, OK

National Rencwable Energy Laboratory, CO

Naval Petroleum Rescrve Nos. 1 \& 2, CA

Niagara Falls Storage Site, NY

Oak Ridge National Laboratory, TN (at Oak Ridge Reservation)

Olympia Substation, WA

Ostrander Substation, OR (Oregon City, OR)
Pacific Northwest National Laboratory, WA (at Hanford Site)

Parker Dam Switchyard, CA

Pittsburgh Energy Technology Center, PA

Port Angeles, WA

Princeton Plasma Physics Laboratory, NJ

Rock Springs Oil Shale Retort, WY

Ross Aviation, Inc., NM

Ross Complex, WA

Sishc Foundry Site, NE

Snohomish Substation, WA

Snow King Substation, WA

Stanford Linear Accelerator Center, CA

Texaco Section 8 Central Solid Waste Site, CA

Texaco Section 8 Gas Plant, CA

Tracy Pump and Substation, CA

Troutdale Substation, OR

Watertown Maintenance Facility, SD

Weeks Island, LA

West Hackberry Site, LA

Western Environmental Technology Office, MT

Yucca Mountain Sitc, NV

Figure II-2. DOE Facilities/Sites Subject to Section 120 of CERCLA and Not in the Nuclear Weapons Complex - Key (Continued) 
similar to those found at these types of facilities in the private sector. These problems resulted primarily from spills and leaks, and from past materials and waste management practices that would generally be considered inadequate by today's standards.

\section{II.D. EM Approach to Environmental Restoration}

The EM approach to environmental restoration of nuclear weapons sites involves setting values and goals for the program and developing different types of approaches for achieving these goals. EH supports EM in the implementation of this approach. Values, goals, and approaches are discussed below.

Values and Goals for the Environmental Restoration Program

The Environmental Restoration Strategic Plan (DOE/EM-0257) was published in August 1995. It identified the following core values for the Environmental Restoration program:

- Ensure protection of worker and public health and safety and the environment;

- $\quad$ Serve as a model steward of natural and cultural resources;

- Comply with Federal, state, and local statutes,

- $\quad$ Prudently use taxpayers' money in achieving tangible results;

- Focus on customer satisfaction and collaborative decision making; and

- Demonstrate a commitment to excellence.

The plan divides the Environmental Restoration program's sites and facilities into five program areas based on site characteristics. The following paragraphs identify the types of sites in each area and specify DOE's Environmental Restoration goals for the sites in each area.

Formerly Utilized Sites Remedial Action Program (FUSRAP) - FUSRAP was established as an initiative of the Atomic Energy Commission in 1974 when the Commission realized that properties previously released did not meet applicable radiation protection requirements. There are currently 46 sites located in 14 states that are in the FUSRAP program. Remediation has been completed at 22 of these sites.

The FUSRAP program area encompasses sites where the Federal government formerly contracted with private firms to perform atomic weapons research. FUSRAP sites on the NPL include the St. Louis Site and Vicinity Properties (Missouri), the Maywood Site (New Jersey), and the Wayne Site (New Jersey). FUSRAP is authorized under Congressional mandate.

Goals of the Environmental Restoration program for FUSRAP program area sites are to:

- $\quad$ Address immediate risk concerns and prevent further increases in relative risk at all sites;

- $\quad$ Complete 50 percent of current FUSRAP sites (23 of 46) by the end of 1996;

- $\quad$ Complete remediation of all FUSRAP sites and related vicinity properties by FY 2016.

The Uranium Mill Tailings Remedial Action (UMTRA) Project - The UMTRA project program area encompasses sites that are or were contaminated with tailings and other by-products of former uranium operations. The UMTRA project is scheduled for completion by FY 98 and is authorized under its own legislation (the Uranium Mill Tailings Radiation Control Act of 1978). The Grand Junction 
Projects Office Remedial Action Project is the largest UMTRA site. It is the only UMTRA site on the docket published April 11, 1995.

Goals of the Environmental Restoration program for UMTRA project program area sites are to:

- $\quad$ Address immediate risk concerns and prevent further increases in relative risk at all sites;

- Complete surface remediation of all 24 mill tailings sites and related vicinity properties by 1998; and

- Complete groundwater activities by 2014 .

Other Small Sites - Other small sites are sites that are not in the UMTRA project or FUSRAP program and that have an estimated cost to complete remedial activities (FY 95 and beyond) of less than $\$ 150$ million. Other small sites included in this CERCLA Annual Report are the Santa Susana Field Laboratories (Energy Technology Engineering Center), the Laboratory for Energy-Related Health Research (LEHR), and the Pinellas Plant. Goals of the Environmental Restoration program for the small sites program area are to:

- $\quad$ Address immediate risk concerns and prevent further increases in relative risk at all sites;

- Complete remediation and decommissioning of 25 sites (out of 36 total sites) by FY 2000; and

- Maximize beneficial reuse of small site lands and facilities.

Large Site Decommissioning - The decommissioning program area addresses contamination at thousands of surplus facilities and structures at large sites across the DOE complex. Surplus facilities and structures include reactors, chemical processing facilities, and warehouses. CERCLA 120 sites in the large site decommissioning program include the Rocky Flats Environmental Technology Site, Idaho National Engineering Laboratory, Hanford Site, Savannah River Site, and Oak Ridge Reservation. Goals of large site decommissioning program area are to:

- Address immediate risk concerns and prevent further increases in relative risk at all sites; and - $\quad$ Reduce long-term costs associated with maintaining surplus facilities and structures.

Large Site Remedial Action - The large site remedial action program area includes sites with a total estimated cost to complete the remedial action of greater than $\$ 150$ million (FY 95 and beyond). NPL sites in the large site remedial action program include the Rocky Flats Environmental Technology Site, Idaho National Engineering Laboratory, Hanford Site, Savannah River Site, and Oak Ridge Reservation. Goals of the large site remedial action program area to:

- Address immediate risk concerns and prevent further increases in relative risk at all sites;

- Sequence work based on program priorities; and

- Make sites, or portions thereof, available for public use.

\section{Analytic Approaches}

During FY 95, analytic approaches to achieving Environmental Restoration goals were identified and evaluated by working groups focusing on technical scope; program management; technology applications; risk management; environment, safety and health; customer focus; performance measures; and contract strategies. Two areas of specific focus in FY 95 were the implementation of contracting 
reform initiatives and the development of a joint EPANDOE policy on decommissioning DOE facilities under CERCLA.

In the contract reform area, DOE awarded its first performance-based Environmental Restoration contract for cleanup of the Rocky Flats Environmental Technology Site during FY 95. The terms of the contract provide specific objectives and goals in key areas and disciplines. It is up to the contractor to decide how to best meet the specific objectives and goals in key areas and disciplines, and to decide how to best meet the specific objectives and goals of the contract.

The joint EPA/DOE policy on decommissioning DOE facilities under CERCLA, published on May 22, 1995, recognizes that decommissioning activities must be conducted in a manner consistent with CERCLA response authority and in conjunction with EPA and DOE stakeholders. It specifies that decommissioning activities should be conducted as non-time-critical removals, unless circumstances at the facility indicate otherwise.

Technical Approaches

Technical approaches to meeting Environmental Restoration goals have included continued progress in the development of remediation technologies and implementation of the Streamlined Approach for Environmental Restoration (SAFER) methodology to Environmental Restoration projects. Recent efforts related to remediation technology development and SAFER implementation are described below.

Ten remediation technologies have been given top priority to expedite DOE cleanup by DOE senior managers. These technologies have been designed to address contamination from underground plumes and landfills, decommissioning, and mixed waste treatment.

DOE developed the SAFER process to reduce the time and cost of performing Environmental Restoration. It combines elements of the Data Quality Objectives process, which defines the quality and quantity of data needed to resolve a problem, and the Observational Approach, which provides an operational approach for managing the inherent uncertainty of remedial activities.

In 1994-1995, DOE and EPA evaluated the effectiveness of the SAFER on pilot projects at the Hanford Site, Mound, Oak Ridge Reservation, and the Savannah River Site. A final report describing the accomplishments of these projects will be issued in 1996. DOE has also begun to implement SAFER principles at additional Environmental Restoration locations.

\section{II.E. Related EM Efforts}

Besides the CERCLA Annual Report, DOE publishes a number of other legally required reports on the progress of the Department's Environmental Restoration program and on the management of environmental restoration-generated waste. In addition, DOE participates in inter-agency activities dedicated to Federal Facility Compliance efforts. Some of these reports and activities are briefly described below.

\section{Baseline Environmental Management Report}

In March 1995, DOE submitted the first Baseline Environmental Management Report to Congress on the activities and projects necessary to carry out the environmental restoration of all DOE defense 
nuclear facilities. The report was prepared to satisfy the requirements of Section 3153 of the 1994 National Defense Authorization Act. The Baseline Environmental Management Report contains detailed information on the environmental restoration activities at all of the nuclear weapons complex facilities that are subject to Section 120 of CERCLA. The Baseline Environmental Management Report will be updated in FY 96.

\section{Waste Management Programmatic Environmental Impact Statement}

In August 1995, DOE published a Draft Waste Management Programmatic Environmental Impact Statement which examines the environmental impacts of different siting and management alternatives for radioactive and hazardous wastes. These wastes resulted from the development, production, and testing of nuclear weapons at a variety of sites located around the United States.

The alternatives were evaluated for waste stored, buried, or to be generated from future operations over the next 20 years at 54 sites. For each waste type, the analyses contained in the Waste Management Programmatic Environmental Impact Statement examine the potential health and environmental impacts of integrated waste management program alternatives involving multiple sites, as well as the potential cumulative impacts. The Final Waste Management Programmatic Environmental Impact Statement is scheduled to be completed in FY 96.

\section{Federal Facility Compliance Act Report to Congress}

Under the Federal Facility Compliance Act of 1992, DOE was required to develop site treatment plans for treating mixed wastes in accordance with RCRA regulations. (The Federal Facility Compliance Act defines mixed wastes as waste that contains hazardous waste and source, special nuclear, or byproduct waste subject to the Atomic Energy Act.) The site treatment plans cover waste in storage, as well as Environmental Restoration waste that may be generated in the next few years.

The final Federal Facility Compliance Act Report to Congress was published in December 1995. It contains information on the:

- Identification of facilities for which DOE submitted site treatment plans to EPA or RCRAauthorized states;

- Status of state and EPA review and approval of each plan; and

- Number of Federal Facility Compliance Act Orders in effect requiring compliance with these plans.

According to the report, DOE submitted 37 site treatment plans covering 40 sites to appropriate states and EPA in FY 95. Based on the site treatment plans, DOE plans to enter into compliance orders with appropriate states and EPA, as required by the Federal Facility Compliance Act, in early FY 96.

\section{Federal Facilities Environmental Restoration Dialogue Committee}

In FY 95, DOE representatives participated in the drafting of Principles for Environmental Cleanup of Federal Facilities (August 2, 1995) as members of the Federal Facilities Environmental Restoration Dialogue Committee, a Federal advisory committee chartered by EPA and facilitated by the Keystone 
Center in Keystone, Colorado. Committee members agreed to principles concerning Federal facility cleanup. The committee's final report will be published in April 1996.

\section{II.F. Approach to Environmental Restoration Used by Other DOE Organizations}

Bonneville Power Administration (BPA)

The BPA markets and transmits power from 29 Federal dams and one non-Federal nuclear plant in the Pacific Northwest. BPA has built one of the largest and most reliable transmission systems in the United States. Bonneville owns and operates 363 electrical substations and maintains 15,012 circuit miles of transmission lines.

BPA currently has 13 sites on the docket. Only one, Ross Complex, is on the NPL. Of the other docket sites, two, Covington Substation and Celilo Converter Station, are currently undergoing site inspections under CERCLA. Contaminant concerns at Covington include polyaromatic hydrocarbons and PCBs. Celilo is a unique facility within the Bonneville system because power is converted from $A C$ to $D C$ and vice versa, utilizing mercury arc valves. Mercury-contaminated soils have been identified as a result of past maintenance practices associated with this equipment.

The majority of environmental restoration activities at BPA are voluntary cleanups conducted under state authority. The most common contaminant encountered at these sites is non-PCB mineral oil. The contamination is usually contained within the soils immediately surrounding oil-filled equipment. These sites are commonly identified when construction projects or major site modifications involve soil disturbance.

BPA also is in the midst of a long-range multiyear voluntary PCB capacitor replacement program. The purpose of the program is to replace PCB-containing electrical capacitors (which routinely fail, resulting in reportable PCB releases and localized soil contamination) with non-PCB capacitors. This involves taking the substation out of service, removing the old capacitor yard equipment (including metal support racks), excavating soil contaminated in the past with PCBs, and constructing a new nonPCB capacitor yard. In some cases a new yard must be constructed first and brought on line to avoid shutting down a crucial substation; then the old yard can be removed and cleanup initiated. This program is very expensive, but not because of soil remediation costs as much as the cost to purchase new capacitors and properly incinerate the old PCB capacitors. Due to budgetary constraints and operational issues, several substations are prioritized for capacitor replacement each year. Originally, about one-fourth (90 to 100) of BPA's 363 substations had electrical equipment that contained PCBs.

\section{Western Area Power Administration (WAPA)}

WAPA is responsible for the Federal electric power marketing and transmission functions in 15 central and western states encompassing a 1.3 million-square-mile geographic area. WAPA provides power to more than 600 wholesale power customers. These wholesale power customers, in turn, provide service to millions of retail consumers in the States of California, Nevada, Montana, Arizona, Utah, New Mexico, Texas, North Dakota, South Dakota, Iowa, Colorado, Wyoming, Minnesota, Nebraska, and Kansas.

WAPA has nine sites listed on the docket and does not have any sites currently listed on the NPL. The Administration has taken a proactive role by implementing a Facility Evaluation Program. The purpose of this program is to evaluate all Western Area Power Administration facilities for sources of 
oil, hazardous substances, pollutants, or contaminants and suspected releases into the environment. WAPA has also proactively conducted PA/SIs at sites that are potentially contaminated. The Montrose Power Operations Center, located in Montrose, Colorado, notified EPA of hazardous waste storage activities in the early 1980s as did the Watertown Substation in Watertown, South Dakota, and Casper Maintenance Yard in Casper, Wyoming. None of these sites are RCRA hazardous waste treatment, storage, or disposal facilities, but because they have facilities for storage of PCB wastes, the sites were listed on the docket. PAs and screening SI final reports have been completed and submitted to EPA.

\section{Morgantown Energy Technology Center}

Morgantown Energy Technology Center is owned and operated by DOE as a research and development center and is listed on the docket. During 1992 and 1993, it was DOE's lead center for local gasification, fluidized-bed combustion, unconventional gas recovery, gas stream cleanup, heat engines, fuel cells, underground coal gasification, oil shale retorting, combined-cycle component integration, and instrumentation and control technologies.

The environmental management program at the DOE Morgantown Energy Technology Center addresses all areas of environmental concern, including surface water and groundwater quality, air quality, and solid and hazardous waste disposal. The program focuses primarily on the treatment and disposal of industrial, contaminated, and sanitary wastewaters; the disposal of solid and hazardous wastes; the minimization of air pollutant emissions; the monitoring of surface water, groundwater, and air quality at the Morgantown Energy Technology Center site and in the surrounding area; the decommissioning, decontamination, and disposal of onsite research facilities no longer in use; and the identification, characterization, and cleanup of offsite property where Morgantown Energy Technology Center sponsored research and development activities.

\section{Pittsburgh Energy Technology Center}

The Pittsburgh Energy Technology Center is the Federal government's most comprehensive coal technology research center and performs a major role in the Department of Energy's mission to ensure an adequate supply of clean energy from coal. The research programs at Pittsburgh Energy Technology Center emphasize new technologies that hold promise for increasing the industrial use of clean coal in the long term.

The Pittsburgh Energy Technology Center, which is listed on the docket, has developed and implemented a program to identify and evaluate inactive hazardous waste disposal sites to determine the necessity of remediation. This program included a Phase I Site Sampling and Analysis Investigation. The scope of the Phase I Sampling and Analysis Investigation included reviewing present and historical operations of DOE facilities at Pittsburgh Energy Technology Center, particularly as they related to hazardous material use, storage, disposal, and handling. Additionally, previous environmental investigations at the site were reviewed. The previous environmental work was supplemented by the Sampling and Analysis Investigation, and a comprehensive database for the DOE facilities has been compiled.

The Sampling and Analysis Investigation investigated soils, surface water, stream sediments, and groundwater throughout all the areas at the Pittsburgh Energy Technology Center that are occupied or potentially impacted by DOE operations. The work plans utilized for the Sampling and Analysis Investigation included the Sampling and Analysis Plan for the investigation of soils, surface waters, and stream sediments, and the Comprehensive Groundwater Protection Management Plan for the 
investigation of groundwater. An additional component of the Sampling and Analysis Investigation was the Underground Storage Tank Management Plan, which reviewed the compliance status of DOEmanaged underground storage tanks, sought to confirm the uncertain disposition or existence of a number of tanks, and investigated the potential for residual contamination due to the operation or removal of these tanks. 
SECTION III

SITE SUMMARUES FOR FACILITIES ON THE NPL (BY STATE) 


\section{STATUS OF CERCLA ACTIVITIES AT DEPARTMENT OF ENERGY SITES}

This section of the report provides information on the DOE's progress in reaching IAGs; public comments regarding proposed IAGs; instances in which no IAG was reached; progress in conducting RI/FSs; progress in conducting remedial actions and response activities at NPL sites; and progress in conducting remedial action at non-NPL sites.

\section{$\underline{\text { Identification of NPL and Non-NPL Sites }}$}

There are currently 23 DOE sites on the NPL. These sites are presented by state on Table III-1. Table III-1 also includes information relating to when each site was placed on the NPL and the status of the IAG for the site. Figure I-1 shows the location of these facilities. The Hanford Site is presented as one site on the figure; however, four sites (Areas 100, 200, 300, and 1100) are listed separately on the NPL.

\section{III.A. Progress in Reaching Interagency Agreements}

The CERCLA Section 120(e)(2) requires that within 180 days after the EPA's review of an RI/FS, the Federal facility must enter into an IAG (i.e., an agreement between DOE and EPA) for the expeditious completion of all necessary remedial action. It is DOE policy, however, to enter into IAGs addressing both the RI/FS and the implementation of remedial action before the RI/FS is completed. IAGs are revised as necessary to incorporate new information, adjust schedules, and address changing conditions.

IAGs are known by different names at different sites. DOE has entered into the following types of IAGs addressing CERCLA remediation: FFAs, Federal Facility Consent Agreements, and a Tri-Party Agreement. The names of the IAGs used by the site are those cited in this report.

As shown on Table III-1, DOE has entered into IAGs at 20 of the 23 facilities on the NPL.

The three sites for which IAGs have not yet been concluded (Laboratory for Energy-Related Health Research, CA; Paducah Gaseous Diffusion Plant, KY; and Pantex Plant, TX) were added to the NPL during fiscal year 1994 (FY 94). IAGs are currently being negotiated at these sites. DOE has not experienced any failure to conclude an IAG within 180 days after EPA review of an RI/FS.

\section{III.B. Specific Cost Estimates and Budgetary Proposals to Support Environmental Restoration Activities Required by the IAG}

The site summaries presented in Sections IV and V contain dollar amounts that support the environmental restoration activities that are being performed pursuant to CERCLA as specified in IAGs. Consequently, these dollar amounts do not represent the entire environmental restoration budget for the site.

The FY 95 amount in each summary box represents actual dollars spent in FY 95. The FY 96 dollars is the appropriated funding and the FY 97 is the request in the President's Budget. 
Table III-1. U.S. Department of Energy Facilities on the National Prioritics List

\begin{tabular}{|c|c|c|c|}
\hline STATE & SITE NAME & $\begin{array}{l}\text { DATE OF FR' NOTICE } \\
\text { OF NPL LISTING } \\
\end{array}$ & INTERAGENCY AGREEMENT (IAG) STATUS \\
\hline \multirow[t]{3}{*}{ California } & $\begin{array}{l}\text { Laboratory for Energy-Related Health } \\
\text { Research (LEHR) }\end{array}$ & $05 / 31 / 94$ & $\begin{array}{l}\text { Memorandum of Agreement with University of California, Davis, } \\
\text { signed in 1989, revised 1993; Federal Facility Agreement and the } \\
\text { Potentially Responsible Party Agreement are currently being } \\
\text { negotiated. }\end{array}$ \\
\hline & \begin{tabular}{|l} 
Lawrence Livermore National \\
Laboratory - Livermore Site \\
\end{tabular} & $07 / 22 / 87$ & Federal Facility Agreement executed on November 1, 1988. \\
\hline & $\begin{array}{l}\text { Lawrence Livermore National } \\
\text { Laboratory - Site } 300 \\
\end{array}$ & $08 / 30 / 90$ & Federal Facility Agreement signed on June 29, 1992. \\
\hline Colorado & $\begin{array}{l}\text { Rocky Flats Environmental } \\
\text { Technology Site (formerly the Rocky } \\
\text { Flats Plant) }\end{array}$ & $10 / 04 / 89$ & $\begin{array}{l}\text { IAG executed on January 22, 1991; currently under renegotiation; the } \\
\text { new Compliance Agreement is expected to be signed in the fourth } \\
\text { quarter of FY } 96 \text { following public comment. }\end{array}$ \\
\hline Idaho & $\begin{array}{l}\text { Idaho National Engineering } \\
\text { Laboratory (includes Argonne } \\
\text { National Laboratory - West) }\end{array}$ & $11 / 21 / 89$ & $\begin{array}{l}\text { Federal Facility Agreement/Consent Order executed on } \\
\text { December } 9,1991 .\end{array}$ \\
\hline Kentucky & Paducah Gaseous Diffusion Plant & $05 / 31 / 94$ & IAG under negotiation. \\
\hline \multirow[t]{2}{*}{ Missouri } & $\begin{array}{l}\text { St. Louis Site (includes St. Louis } \\
\text { Airport Site and Vicinity Properties, } \\
\text { Latty Avenue Properties) }\end{array}$ & $10 / 04 / 89$ & Federal Facility Agreement signed on June 26, 1990. \\
\hline & $\begin{array}{l}\text { Weldon Spring Site Remedial Action } \\
\text { Project (formerly referred to as } \\
\text { Weldon Spring Quarry and Feed } \\
\text { Materials Plant and Raffinate Pits } \\
\text { Site) }\end{array}$ & $\begin{array}{l}07 / 22 / 87 \\
03 / 13 / 89^{3}\end{array}$ & $\begin{array}{l}\text { Federal Facility Agreement signed on August 22, 1986; amended } \\
\text { June 30, } 1992 .\end{array}$ \\
\hline \multirow[t]{2}{*}{ New Jersey } & Maywood Site $^{2}$ & $09 / 08 / 83$ & $\begin{array}{l}\text { Federal Facility Agreement signed on July 23, 1990, and made } \\
\text { effective in April } 1991 .\end{array}$ \\
\hline & Wayne Site $^{2}$ & $09 / 21 / 84$ & $\begin{array}{l}\text { Federal Facility Agreement signed on July 23, 1990, and made } \\
\text { effective in April } 1991 .\end{array}$ \\
\hline New York & Brookhaven National Laboratory & $11 / 21 / 89$ & IAG executed on February 28, 1992, and made effective May 27, 1992 \\
\hline
\end{tabular}


Table III-1. U.S. Department of Energy Facilities on the National Priorities List (Continued)

\begin{tabular}{|c|c|c|c|}
\hline STATE & SITE NAME & $\begin{array}{l}\text { DATE OF FR' NOTICE } \\
\text { OF NPL LISTING }\end{array}$ & INTERAGENCY AGREEMENT (IAG) STATUS \\
\hline \multirow[t]{2}{*}{ Ohio } & $\begin{array}{l}\text { Fernald Environmental Management } \\
\text { Project }\end{array}$ & $11 / 21 / 89$ & $\begin{array}{l}\text { Consent Agreement made effective on June 29, 1990; amended on } \\
\text { September 20,1991 and April 5, } 1993 \text {. }\end{array}$ \\
\hline & Mound Plant & $11 / 21 / 89$ & $\begin{array}{l}\text { Federal Facility Agreement executed on August 6, 1990; amended on } \\
\text { July 15, } 1993 \text {. }\end{array}$ \\
\hline South Carolina & Savannah River Site & $11 / 21 / 89$ & $\begin{array}{l}\text { IAG executed on January } 15,1993 \text {, and made effective on August } 16 \text {, } \\
1993 .\end{array}$ \\
\hline Tennessee & Oak Ridge Reservation & $11 / 21 / 89$ & IAG made effective on January $1,1992$. \\
\hline Texas & Pantex Plant & $05 / 31 / 94$ & Federal Facility Agreement under negotiation. \\
\hline \multirow[t]{2}{*}{ Utah } & Monticello Mill Site & $11 / 21 / 89$ & Federal Facility Agreement executed on December 22, $1988 .^{4}$ \\
\hline & Monticello Vicinity Properties & $06 / 10 / 86$ & Federal Facility Agreement executed on December 22, 1988. ${ }^{4}$ \\
\hline \multirow[t]{5}{*}{ Washington } & Hanford Site - Area 100 & $10 / 04 / 89$ & $\begin{array}{l}\text { Tri-Party Agreement signed on May 15, 1989; amended in 1991, 1992, } \\
1994 \text {, and on July 28, } 1995 \text {. }\end{array}$ \\
\hline & Hanford Site - Arca 200 & $10 / 04 / 89$ & $\begin{array}{l}\text { Tri-Party Agreement signed on May 15, 1989; amended in 1991, 1992, } \\
1994, \text { and on July 28, } 1995 \text {. }\end{array}$ \\
\hline & Hanford Site - Area 300 & $10 / 04 / 89$ & $\begin{array}{l}\text { Tri-Party Agrecment signed on May 15, 1989; amended in 1991, 1992, } \\
\text { 1994, and on July 28, } 1995 \text {. }\end{array}$ \\
\hline & Hanford Site - Area 1100 & $10 / 04 / 89$ & $\begin{array}{l}\text { Tri-Party Agreement signed on May 15, 1989; amended in 1991, 1992, } \\
1994 \text {, and on July 28, } 1995 \text {. }\end{array}$ \\
\hline & $\begin{array}{l}\text { Ross Complex (part of the Bonneville } \\
\text { Power Administration) }\end{array}$ & $11 / 21 / 89$ & IAG executed on May l, 1990. \\
\hline
\end{tabular}

FR $=$ Federal Register

2 Congress directed DOE to remediate these sites. The states (New Jersey and Missouri) are not parties to these IAGs.

3 The Feed Materials Plant and Raffinate Pits were added to the site 3/13/89.

4 One IAG was developed for both Monticello sites, but the sites are listed separately on the NPL. 


\section{III.C. Public Comments Regarding Proposed Interagency Agreements}

During FY 95, no new IAGs were proposed. Consequently, there were no public comments regarding proposed IAGs.

Negotiations on Amendment 6 of the Hanford Tri-Party Agreement will be completed in FY 95 and the 45 day public comment period will end in FY 95. Public comments regarding the renegotiated agreement will be discussed in next year's CERCLA 120 report.

Discussions began in FY 93 between DOE and regulatory agencies regarding amendments to the IAG at the Rocky Flats Environmental Technology Site. The public has been kept abreast of this activity, and a preliminary draft of the amended IAG was made available for informal public comment in FY 95. Negotiations on the amended IAG are expected to be completed in FY 96 and the 60-day public comment period is expected to end in FY 96.

\section{III.D. Instances in Which No Interagency Agreement Was Reached}

There is no instance where DOE has failed to reach an IAG within 180 days of the completion of EPA's review of an RI/FS. As mentioned earlier, the three NPL sites where DOE has not yet entered into IAGs-the Laboratory for Energy-Related Health Research (LEHR), CA; Paducah Gaseous Diffusion Plant, KY; and Pantex Plant, TX-were placed on the NPL in FY 94. DOE expects to sign IAGs for these facilities before the RI/FSs for these facilities are completed.

\section{III.E. Progress in Conducting Remedial Investigations/Feasibility Studies at NPL Sites}

CERCLA Section 120(e)(1) specifies that RJ/FS work must be initiated within 6 months after a site is listed on the NPL. RI/FS work was initiated within this statutory time frame at all 23 DOE facilities on the NPL.

Highlights of FY 95 RI/FS accomplishments are listed below.

Brookhaven National Laboiratory - An RI/RA, an RI/FS Work Plan, a draft PP, and draft ROD were submitted to the EPA and State of New York. A groundwater removal action draft EE/CA and action memorandum were also submitted to EPA and the state.

Fernald Environmental Management Project - One RI Report, three draft RODs, two draft Remedial Design Work Plans, one FS/PP, one RJ/FS/PP, and one RD/RA Work Plan were submitted. Two RI Reports, three RODs, two Remedial Design Work Plans, two FS/PPs, and one RD/RA Work Plan were approved. Three RODs were issued.

Hanford Site (Areas 100, 200, 300, and 1100) - Nine PPs, ten FS Reports, one Phase 3 FS Report, one Phase 2 RI Report, and two Limited Field Investigation Reports were submitted. Three RODs were issued.

Idaho National Engineering Laboratory - RIFS activities are complete or underway at all of the ten waste area groups (WAGs).

Lawrence Livermore National Laboratory - Site 300 - Draft and final FSs for the General Services Area (GSA) OU 1 were submitted in FY 95. The Final FS for OU 3 was submitted in FY 95. 
Maywood Site - Comments on the PP were provided in September 1995, and it will be released for public comment in FY 96.

Monticello Mill Site - The Draft Final OU 3 RI/FS Work Plan, Field Sampling Plan, and Quality Assurance Project Plan were submitted for regulatory review in September 1995. Soil, sediment, surface water, groundwater, and biota sampling in support of the RI was completed in summer/fall 1995.

Mound Plant - OU 1 ROD was completed, and the design phase of the Miami-Erie canal removal action was initiated. The EPA approved the sale or lease of a 30-acre parcel of land. A plan was initiated to accelerate cleanup of the entire plant.

Oak Ridge Reservation - Submittal of one RI/FS, five PPs, and two RODs were accomplished in FY 95. One RI and RI/FS was completed in FY 95.

Paducah Gaseous Diffusion Plant - Two interim action RODs were approved. Two RI Reports and one RI addendum was completed.

Pantex Plant - In FY 95, the assessment phase for eight projects was completed.

Rocky Flats Environmental Technology Site - Two RODs were completed and approved by regulatory agencies in FY 95. Two Final Phase I RI Reports and one Final FS Report were completed. Two IM/IRA decision documents were submitted.

Savannah River Site - Fifteen RFI/RI Plans, 13 RFI/RI and Baseline Risk Assessments, three RD/RA Work Plans, two Corrective Measures Studies/FS Reports, and 24 Site Evaluation Reports were submitted. Four remedial RODs were signed.

St. Louis Site - The FS was completed and submitted to EPA and the State of Missouri for review. EPA and DOE have agreed to postpone the submittal of the PP to accommodate recommendations from the St. Louis Citizens Task Force on a selected remedy.

Wayne Site - The PP for the site was developed, EPA Region II provided comments on the Plan in September 1995, and it will be released for public comment in FY 96.

Weldon Spring Site Remedial Action Project - The Site Groundwater Sampling Plan was completed in August 1995, and the joint Remedial Action Work Plan (prepared with the Department of the Army) for the Site Groundwater Operable Unit was completed in May 1995.

\section{III.F. Progress in Conducting Remedial Actions at NPL Sites}

CERCLA Section $120(e)(2)$ requires that substantial, continuous, physical, onsite remedial action commence at each facility not later than 15 months after completion of the RU/FS. During FY 95, several sites made significant progress in their remedial actions. Highlights of some of the activities that occurred in FY 95 are listed below.

Hanford Site (Areas 100, 200, 300, and 1100) - Cleanup was completed in the 1100 Area. More than 11 million gallons of groundwater have been treated and the past-practice disposal facility (the Environmental Restoration Disposal Facility) started construction. 
Idaho National Engineering Laboratory - Thirty No Further Action determinations were approved following the guidance as outlined in the FFA/Consent Order.

Lawrence Livermore National Laboratory - Livermore Site - Currently, five groundwater treatment facilities are operating, with hydraulic control of the western offsite plume established, including dramatic reductions in contaminant concentrations.

Maywood Site - Remedial action at five vicinity properties was completed in 1995.

Mound Site - Seven removal actions were completed. A 30-acre parcel was declared clean for other uses.

Monticello Mill Site - At the Mill Site OU 1, construction of the staging area, including decontamination facilities, haul roads, and the runoff retention pond, was completed; installation of surface water drainage control structures is near completion. At the Mill Site OU 2, remedial action began on three peripheral properties and was completed on one property in FY 95. In addition, there were six project starts and six project completions in FY 95.

Monticello Vicinity Properties - Remedial actions were completed for 81 Monticello Vicinity Properties in FY 95. Remedial actions on 375 vicinity properties out of a project total of 411 properties have been completed through FY 95.

Oak Ridge Reservation - Five interim actions were completed and two remedial actions proceeded to the construction phase.

Rocky Flats Environmental Technology Site - During FY 95, sludge removal was completed at the OU 4 solar ponds. Design of a passive leachate collection system for the OU 7 present landfill was also completed.

Ross Complex - Cleanup of the Capacitor Test Job, initiated in January 1994, is now complete. Installation of a multilayer cap over the Fog Chamber Dump was completed in October 1994. Soil treatments for the contaminated soil excavated from the Wood Pole Storage Yard are continuing and are expected to be completed in FY 96. Cleanup of the substation capacitor yard, including the replacement of PCB equipment, was initiated and is expected to be completed early in FY 96 . This PCB removal is the last of the remediation activities included in the RODs.

Savannah River Site - Five remedial actions were completed.

Weldon Spring Site Remedial Action Project - Construction was completed and testing initiated for a Pilot Sludge Processing Facility. Additionally, Weldon Spring Site Remedial Action Project completed acquisition of 2 million cubic yards of soil in the Soil Borrow Area from the State of Missouri in July 1995.

\section{III.G. Progress in Conducting Removal and Interim Actions at NPL Sites}

Response actions other than remedial action activities were taken during FY 95. These actions were primarily removal or interim actions designed to provide prompt or immediate response to actual or potential threats of a release of hazardous substances to the environment. Highlights of some of the activities that occurred in FY 95 are listed below. 
Brookhaven National Laboratory - Six major removal actions are planned or are underway. In FY 95, 23 Cesspool removal actions were completed, the D-Tanks removal action was completed, 4 underground storage tanks were cut and packaged and the wastes were shipped offsite, and the landfill capping was initiated and is expected to be completed in early FY 96.

Fernald Environmental Management Project - Three removal actions were completed in FY 95. An additional eight removal actions have been planned or are underway.

Hanford Site (Areas 100, 200, 300, and 1100) - An EE/CA for the expedited construction of a barrier wall and the start of a pump and treat system at $\mathrm{N}$-Springs was completed. In addition, the carbon tetrachloride vapor extraction system at $200-\mathrm{ZP}-2$ is now automated.

Idaho National Engineering Laboratory - Activities are continuing on five removal actions. Two interim actions were completed and activities continued on three other interim actions.

Lawrence Livermore National Laboratory - Site 300 - Two interim groundwater treatment facilities continued operations, and the Interim Soil Vapor Extraction Facility at Building 834 was restarted.

Maywood Site - Maywood Interim Storage Site Pile removal operations began in FY 95. Approximately 40 percent of the waste has been removed.

Oak Ridge Reservation - Two removal actions and five interim actions were completed.

Paducah Gaseous Diffusion Plant - The plant completed construction and began operation of two interim actions. Activities continued on one removal action and two interim actions from previous years.

Pantex Plant - Five removal actions were completed, well ahead of the Facility Action Plan requirement. Per priority number 1 in the Environmental Restoration Strategic Plan, a high-explosivecontaminated groundwater treatment system was installed in FY 95.

Rocky Flats Environmental Technology Site - A groundwater collection and treatment IRA facility at OU 1 and a surface water collection and treatment IRA at OU 2 continued operation throughout FY 95. Work continued in FY 95 on Option B Offsite Water Projects to replace the drinking-water supply for the city of Broomfield, Colorado. Design of the system has been completed, and pipeline construction from the alternate water source is well underway. Ten Accelerated Actions were completed.

Ross Complex - Continued groundwater monitoring of OU B is planned for the next 3 years unless a review of conditions demonstrates that the groundwater quality is stable and additional monitoring is unnecessary.

Savannah River Site - Fifteen Interim Actions were completed.

St. Louis Site - Remedial action was performed at six residential vicinity properties in FY 95. An additional eight vicinity properties are scheduled for remedial action in FY 96. 
Wayne Site - A non-time-critical removal action was initiated in FY 95 to dispose of contaminated material from the interim storage pile. The waste was disposed of at a commercial disposal facility in Utah.

Weldon Spring Site Remedial Action Project - The demolition of four more Chemical Plant buildings was completed in December 1994. The site completed excavation of 72,883 cubic yards in the Quarry Bulk Waste removal effort in September 1995, for a cumulative excavated volume of 116,000 cubic yards (approximately 96 percent of the total anticipated volume).

Additional information on cleanup initiatives undertaken at DOE NPL facilities is provided in the detailed narratives found in Section III of this report.

\section{III.H. Progress in Performing Cleanup Activities at Facilities Not on the NPL}

Many DOE facilities that are not listed on the NPL are conducting cleanup activities. Additional information on cleanup initiatives undertaken at facilities not listed on the NPL is provided in the detailed narratives found in Section V of this report. Highlights of some of the activities that occurred in FY 95 are presented below.

Nevada Test Site - A preliminary Risk Assessment and Draft Cost/Benefit Analysis for large areas of soils contaminated with plutonium from past activities were completed. One remediation (SAFER Closure of 5 Point Landfill), 22 Interim Actions (removal of 12 underground storage tanks and 10 septic tanks), four assessments, and one decommissioning (Junior Hot Cell) project were completed. Additional characterization and groundwater monitoring wells were installed as part of an effort to develop a regional groundwater model for predicting contaminant transport. The Underground Test Area RJ/FS project regional groundwater modeling effort is scheduled for completion late in 1996. 
SECTION IV

SITE SUMMARIES FOR FACILITIES ON THE NPL (BY STATE) 


\section{SITE SUMMARIES FOR FACILITIES ON THE NPL (BY STATE)}

This section of the annual report to Congress provides a detailed description of progress made at each of the $23 \mathrm{DOE}$ facilities currently on the NPL. The information provided includes each facility's NPL status, background summary information, environmental conditions, and funding information. Each of the applicable CERCLA Section 120(e)(5) information requirements is also addressed. The geographic location of these sites is identified in Figure I-1. 
This Page Intentionally Left Blank.

IV-2 


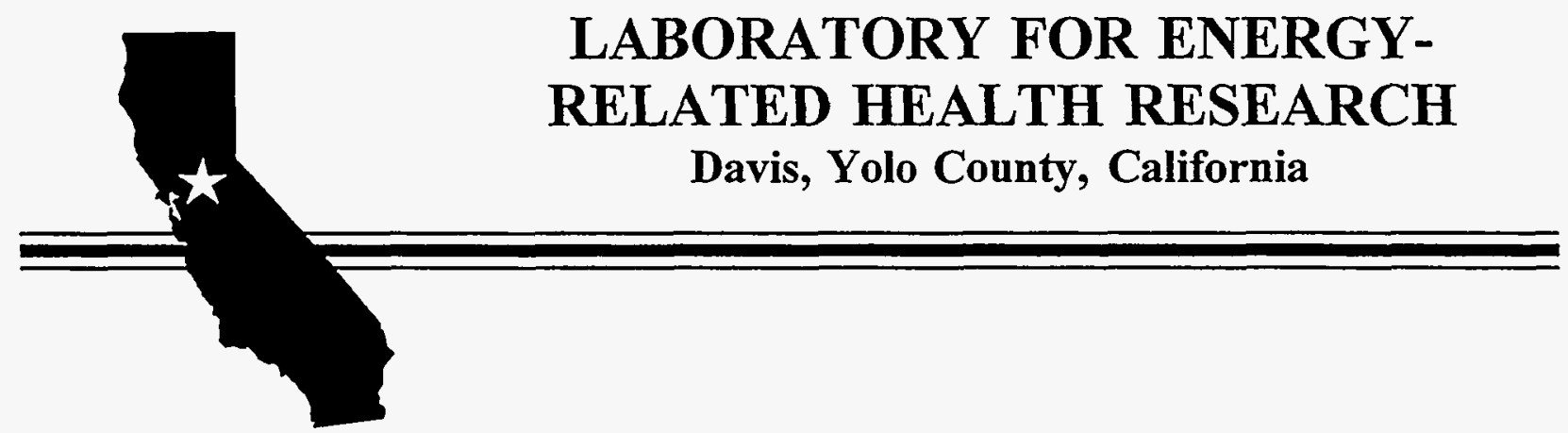

\section{Progress in Reaching Interagency Agreement}

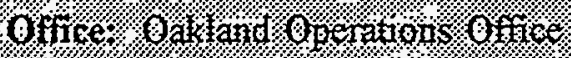

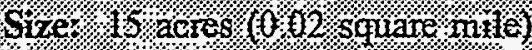

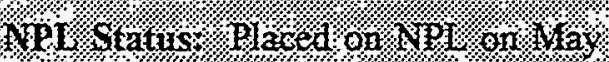
31. 1994

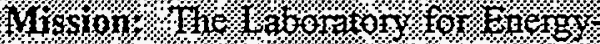

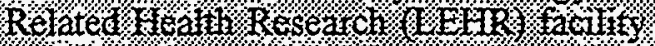

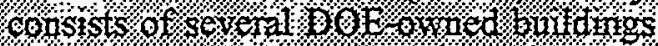

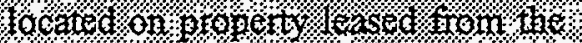

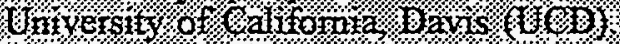

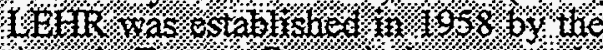

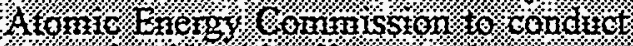

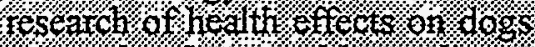

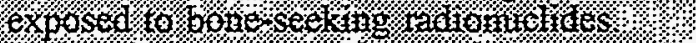

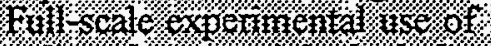

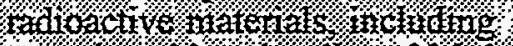

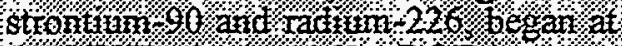

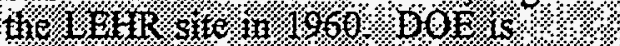

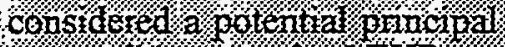

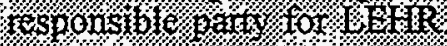

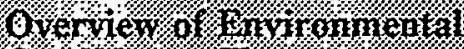
Conditions: Tite contamninants ate

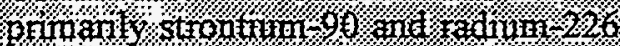

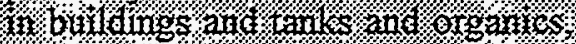

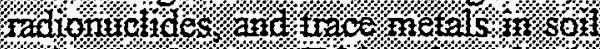

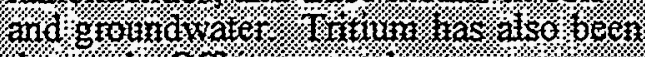
detected: Oftsite groundivater: contamination oonsists: of chromintin and

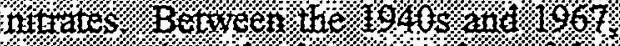

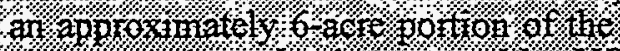

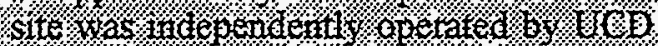

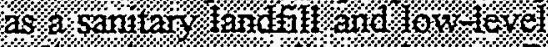

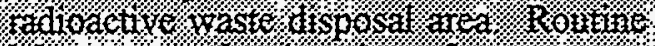

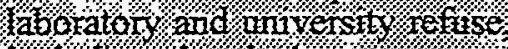

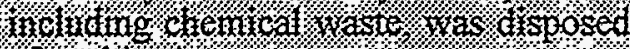
of at Hitis site

CERCLIARCRA RERTediation

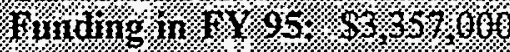

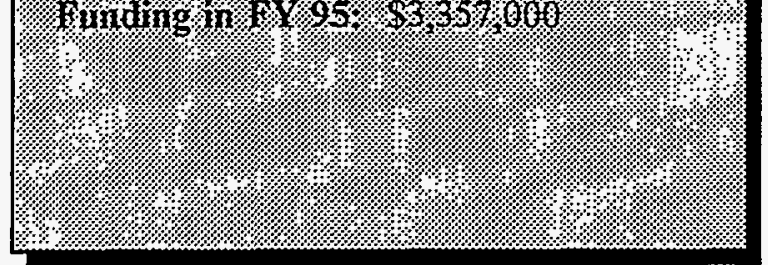

In 1988, DOE terminated the research program and in 1989 signed a MOA with UCD to begin cleanup of the site to return it to UCD. This MOA was amended in 1993 to limit DOE involvement in nonDOE contaminated areas to characterization activity only. DOE, EPA Region IX, and the State of California are currently formulating an FFA for cleanup of LEHR. The FFA will not be formalized until a potentially responsible party Side-Bar Agreement has been executed between DOE and the University of California delineating each party's responsibility for cleanup. The Side-Bar Agreement is expected to be signed in FY 96. The FFA is expected to be signed in FY 96.

\section{Specific Cost Estimates and Budgetary Proposals Involved in Each Interagency Agreement}

Funds budgeted for environmental restoration at LEHR total $\$ 3.0$ million of appropriated funding for FY 96 and $\$ 3.5$ million for FY 97 according to the request in the President's Budget.

\section{Public Comments Regarding Interagency Agreements}

An IAG in the form of an FFA is currently being negotiated and is expected to be completed in FY 96. The neighboring community, special interest groups, local media, and elected officials are concerned about leaking landfills and groundwater contamination. 


\section{Progress in Conducting Remedial Investigations/Feasibility Studies}

The laboratory continued to conduct CERCLA remedial investigations and feasibility studies on soil from landfills and burial trenches, and on groundwater.

\section{Progress in Conducting Remedial Actions}

In FY 95, the Imhoff Building, including the ion exchange treatment facility and adjacent laboratory, was demolished; the tank trailer was dismantled, compacted, and disposed of; release surveys and independent verification were completed for the two Animal Hospital Buildings and Specimen Storage Rooms; and decommissioning of the Co-60 Building was initiated. 


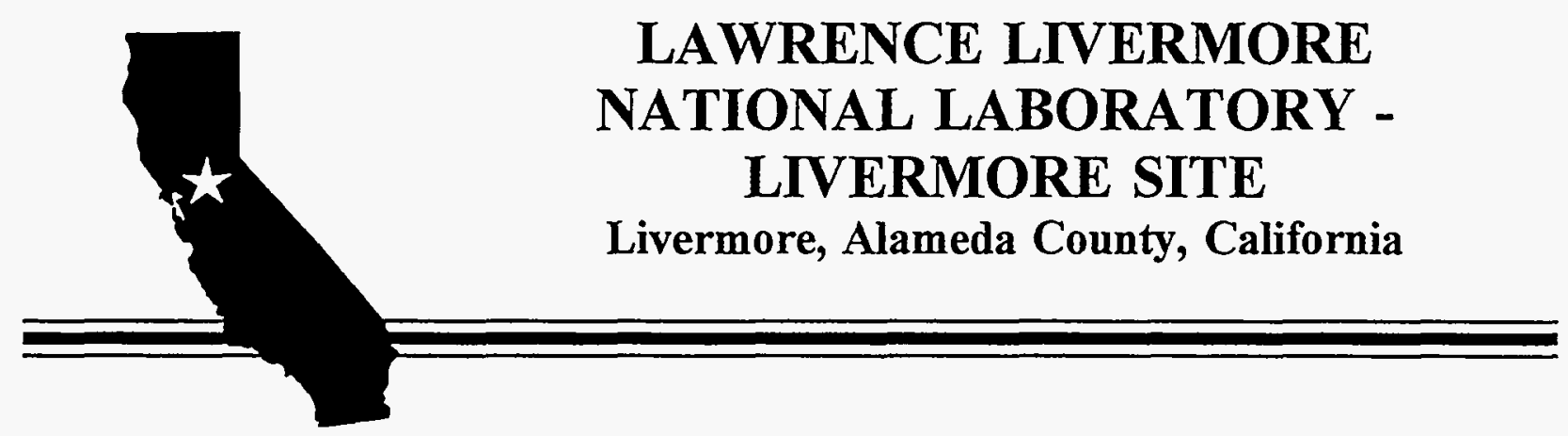

\section{Progress in Reaching Interagency Agreement}

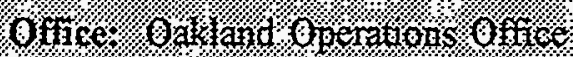

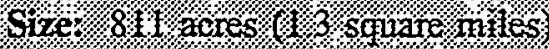

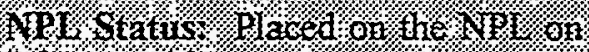
3itit 22, 1987

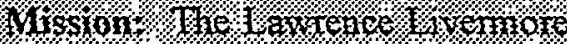

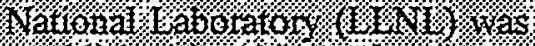

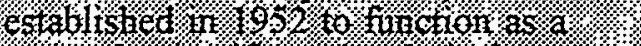

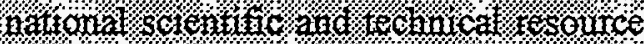

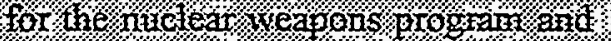

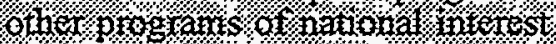

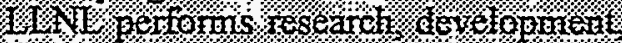

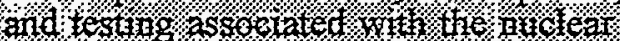

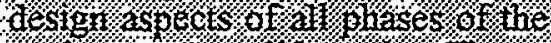

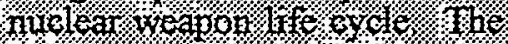

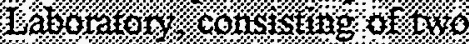

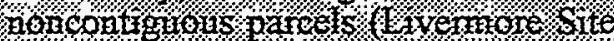

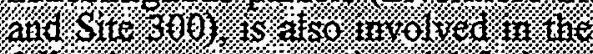

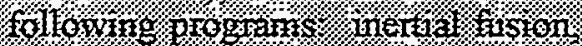

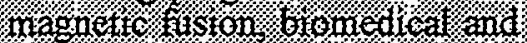

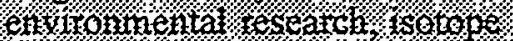
separation, and a philed onets:

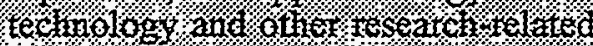
activitites

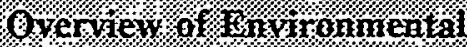
Conditions: Contaritintito: 0 :

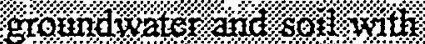

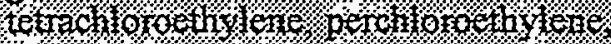

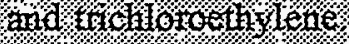

\section{GERR I. I. RCR A Remediation}

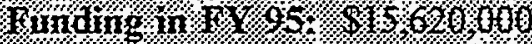

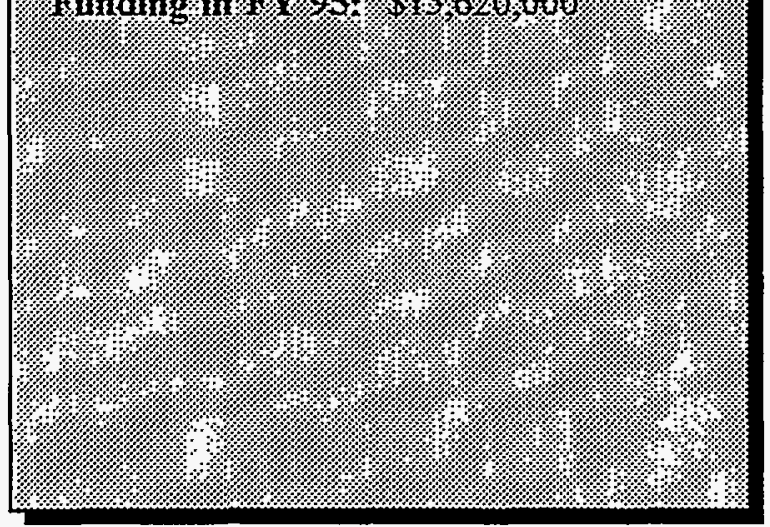

DOE entered into an FFA with EPA Region IX and the State of California for cleanup of the LLNL-Livermore Site. This FFA was executed on November 1,1988 and became effective in February 1989. Significant emphasis was placed on the renegotiation of FFA enforceable milestone deliverables this fiscal year. In June 1994, EPA and the state agencies approved a revised schedule that reprioritized activities to direct the focus on the western and southern perimeters where there is offsite contamination. A treatability study and groundwater facility were added for Trailer 5475 where there are volatile organic compounds and tritium contamination. The Treatment Facility 518 vapor extraction system was also included in the schedule.

\section{Specific Cost Estimates and Budgetary Proposals Involved in Each Interagency Agreement}

Funds budgeted for environmental restoration to support the FFA milestones at the LLNL-Livermore Site total $\$ 12.7$ million of appropriated funding for FY 96 and \$12.7 million for FY 97 according to the request in the President's Budget.

\section{Public Comments Regarding Interagency Agreements}

No new comments on the FFA were received in FY 95. An IAG in the form of an FFA became effective in 1989; as a result, a technical assistance group is in place. This group continues to support a community working group to review post ROD documents and to provide input into the recent renegotiations and priorities of the site remediation efforts. 


\section{Progress in Conducting Remedial Investigations/Feasibility Studies}

The Draft Final FS was submitted to the state and EPA in December 1990 and the proposed Remedial Action Plan was submitted in October 1991, in preparation for the November 1991 public hearing on the proposed plan for onsite remediation activities. A responsiveness summary for the public comments and final ROD was approved by DOE in June 1992.

\section{Progress in Conducting Remedial Actions}

The ROD for the LLNL-Livermore Site was approved by DOE, EPA, and the State of Califomia in June 1992. The ROD called for cleanup of soil and groundwater using seven treatment facilities and 24 initial extraction locations. In FY 95, a draft Compliance Monitoring Plan was completed. In FY 95, Treatment Facility 518 was constructed and operation started. Currently, five treatment facilities are in operation. Hydraulic control of the western offsite plume was established in FY 95, including a dramatic decrease in offsite contaminant concentrations. Additionally, a successful demonstration of the Dynamic Underground Stripping Technology was performed at the Gasoline Spill Area, which resulted in the removal of approximately 10,000 gallons of fuel hydrocarbons.

In FY 95, Final Remedial Design Reports Numbers 5 and 6 were completed and issued. Negotiations with regulators were conducted that reduced reporting requirements. Treatment Facility $F$ vadose zone remediation was completed and groundwater pumping ceased for 6 months. Treatment Facility A North and Treatment Facility B North pipelines were constructed and activated, and the underground tank at Building 292 was sealed. 


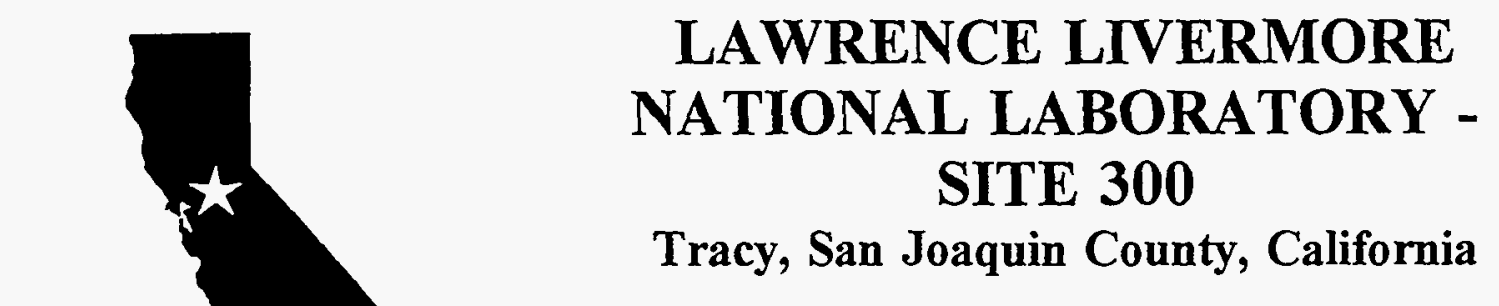

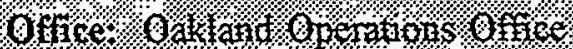

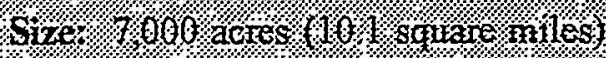

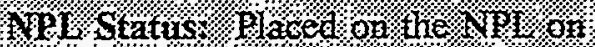

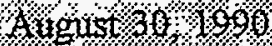

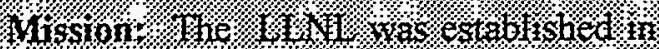

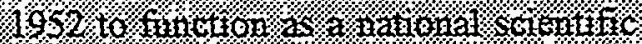

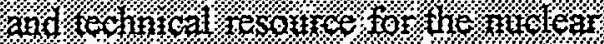

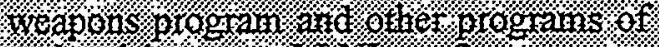

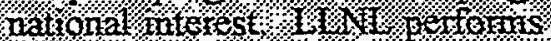

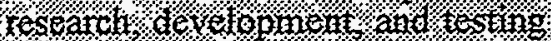

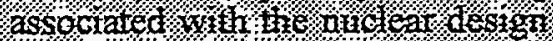

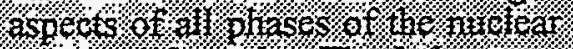

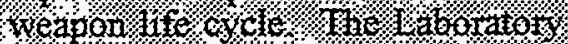

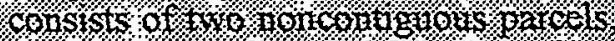

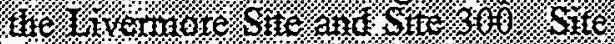

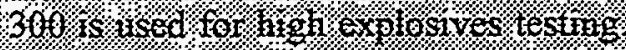

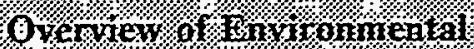

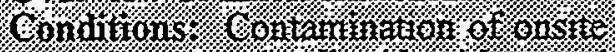

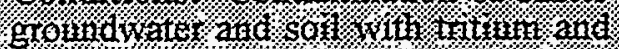

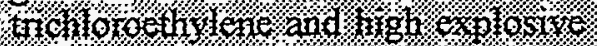
conititontinds:

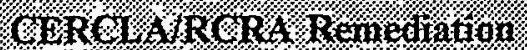

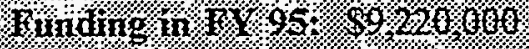

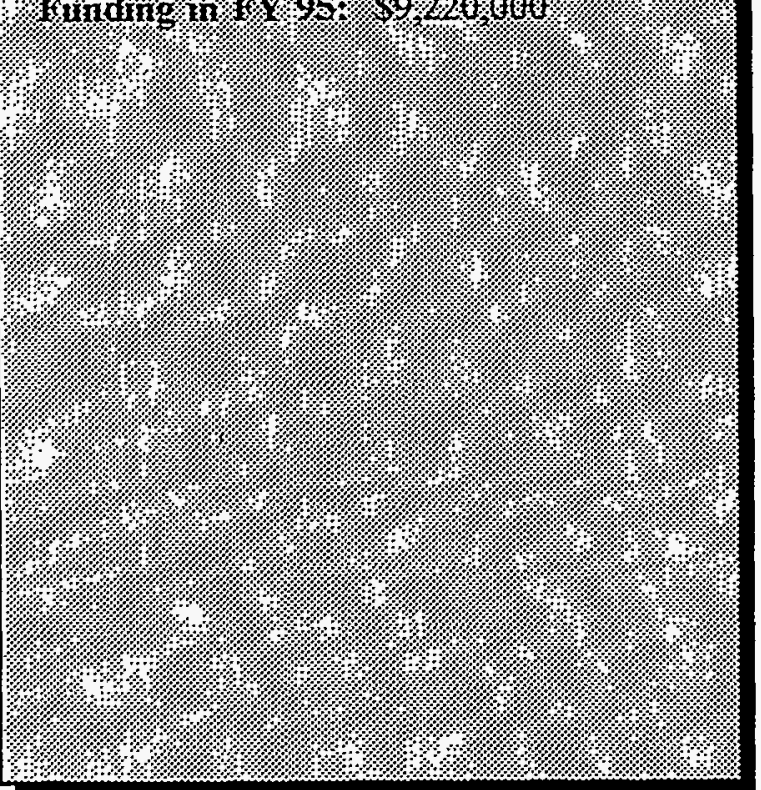

\section{Progress in Reaching Interagency Agreement}

An integrated (CERCLA/RCRA) FFA was negotiated and signed between DOE, EPA Region IX, the California EPA's Department of Toxic Substance Control, and the Central Valley Regional Water Quality Control Board in June 29, 1992. In February 1994 a revised Appendix A (schedule of deliverables) to the FFA was approved by EPA.

\section{Specific Cost Estimates and Budgetary Proposals Involving Each Interagency Agreement}

Funds budgeted for environmental restoration to support the milestones in the FFA at the LLNL-Site 300 total $\$ 10.5$ million of appropriated funding for FY 96 and $\$ 9.8$ million for FY 97 according to the request in the President's Budget.

\section{Public Comments Regarding Interagency Agreements}

All stakeholders and interested parties have been involved in the development of the FFA and subsequent revisions.

\section{Progress in Conducting Remedial Investigations/Feasibility Studies}

Under the terms of the FFA and at the request of the regulatory agencies, the Site 300 Site Wide Remedial Investigation (SWRI) Report was prepared. The final SWRI Report was submitted to the regulators on March 10, 1994. 
DOE, LLNL, and regulatory agency personnel have worked together to "re-engineer" the CERCLA process to expedite cleanup at portions of LLNL-Site 300 that present risks to human health and the environment. The areas of highest priority are the GSA, Building 834, and Building 832 Canyon. GSA and Building 834 are going through the standard CERCLA process of FS, PP, Public Meeting, and ROD. The draft and final FS for the GSA OU and the final FS for OU 3/Pit Complex were submitted in FY 95. The Interim ROD for the Building 834 OU was also completed in FY 95. Building 832 Canyon is in the subsurface investigation phase, and the appropriate CERCLA path will be chosen on completion of the investigation.

\section{Progress in Conducting Remedial Actions}

The Interim Groundwater Facilities at the Eastern and Central GSA have continued to operate, and the Interim Soil Vapor Extraction Facility at Building 834 was restarted. At GSA, the offsite plume was significantly pulled back and offsite contamination was reduced. 


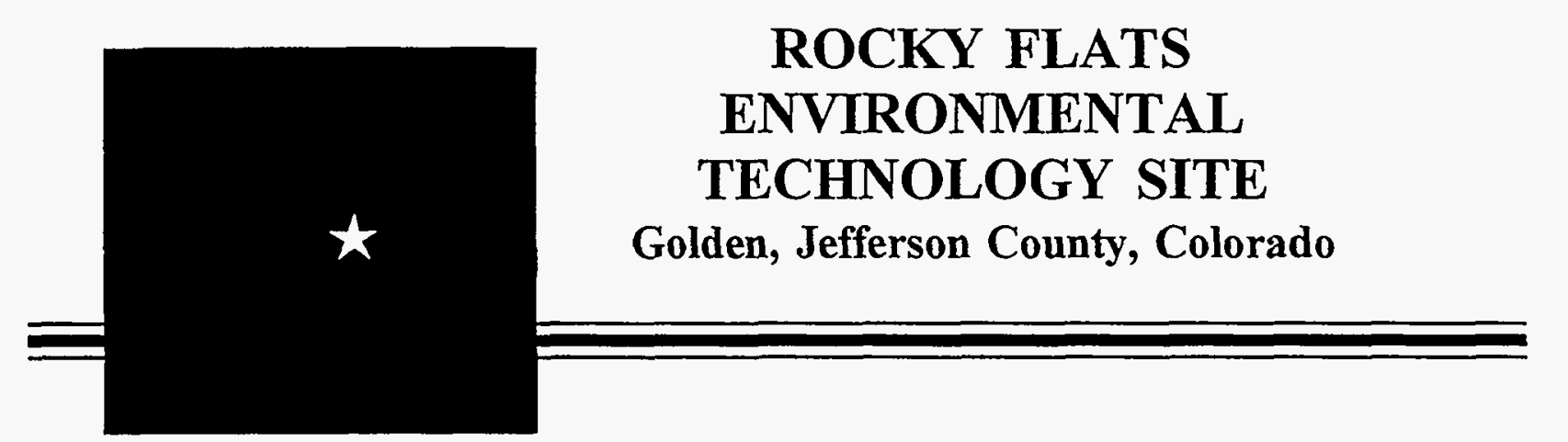

\section{Progress in Reaching Interagency Agreement}

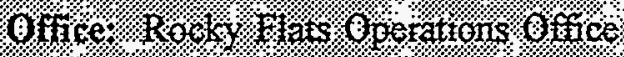

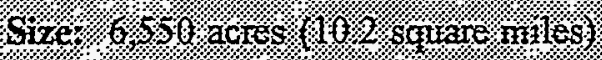

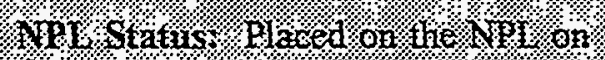

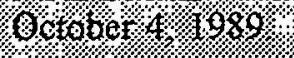

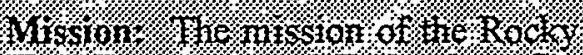

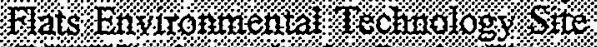

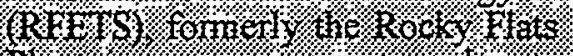

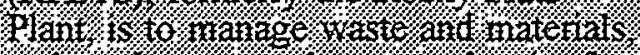

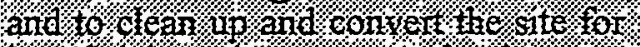

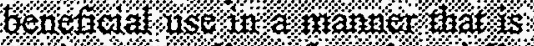

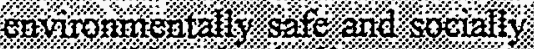

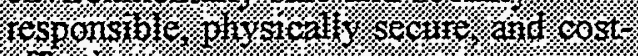
effective.

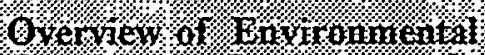

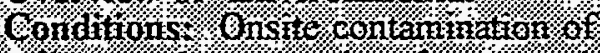

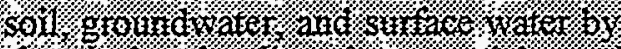

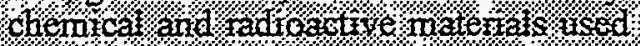

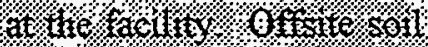

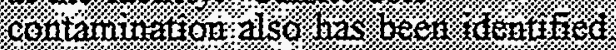

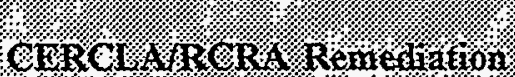

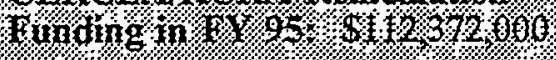

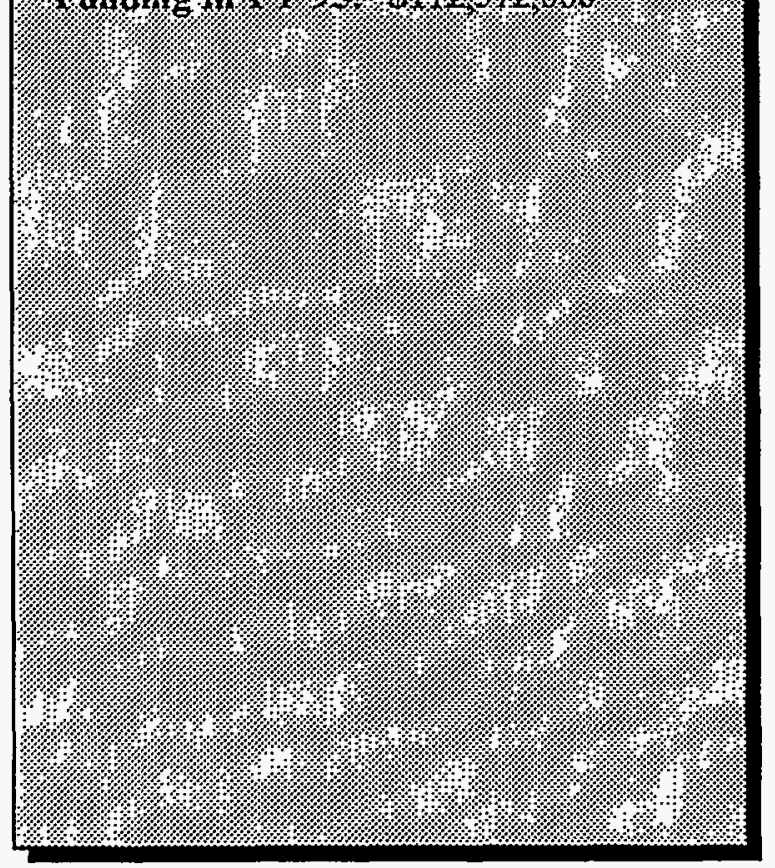

DOE, EPA Region VIII, and the State of Colorado executed an IAG for the RFETS on January 22, 1991. The IAG supersedes the RCRA/CERCLA Compliance Agreement executed on July 31, 1986 among DOE, EPA Region VIII, and the State of Colorado. The IAG establishes cleanup schedules and delineates regulatory responsibilities of EPA Region VIII and the State of Colorado. In January 1994, it was agreed among EPA Region VIII, the Colorado Department of Public Health and Environment (CDPHE), and DOE that a new Rocky Flats Cleanup Agreement will be negotiated to replace the IAG. These negotiations are expected to conclude in a final agreement in the fourth quarter of FY 96.

\section{Specific Cost Estimates and Budgetary Proposals Involved in Each Interagency Agreement}

Funds budgeted for environmental restoration under the IAG total $\$ 37.8$ million of appropriated funding for FY 96 and $\$ 60.3$ million for FY 97 according to the request in the President's Budget.

\section{Public Comments Regarding Interagency Agreements}

Discussions began in FY 93 between DOE and the regulatory agencies regarding negotiation of the new Rocky Flats Cleanup Agreement. The public has been kept abreast of this activity, and a preliminary draft of the agreement was provided for informal comment. The newly formed Citizen Advisory Board discussed issues related to the agreement at some of the recent meetings. The draft of the new cleanup agreement will be made available for public comment when the agencies have reached agreement. 


\section{Progress in Conducting Remedial Investigations/Feasibility Studies}

Initial site characterization efforts at RFETS began in July 1986 under the RCRA/CERCLA Compliance Agreement and continue under the IAG executed on January 22, 1991. A comprehensive list of all known and suspected hazardous, radioactive, and mixed waste sources at the site has been compiled, including descriptions of all known release information for 178 individual hazardous substance sites. These sites have been categorized for further environmental investigation and remediation into 16 OUs based on cleanup priorities, waste type, geographic location, and public input. Since that time, characterization has been completed and no-action RODs have been approved by DOE, EPA, and the CDPHE for three operable units (OUs 11, 15, and 16).

Phase I RI work plans for all OUs have been approved by the regulatory agencies. The number of Phase II and Phase III work plans has been reduced by innovative planning and working with the regulatory agencies to combine phases and subsequent field work for several OUs. Phase I RI field work has been completed for ten OUs and is underway in the remaining six. Seven final and two draft RI reports have been submitted to the regulatory agencies. FSs have been started in four OUs, with one completed (OU 1). In OU 7 presumptive remedies will be used, and no RIs or FSs will be required. Accelerated removal actions conducted under a proposed action memorandum procedure, developed in conjunction with the regulatory agencies, may also reduce the risk at some OUs so that a no-action ROD may be approved, further reducing remediation costs. IM/IRA decision documents are also used to accelerate cleanup, further reducing costs (OUs 2 and 7).

Phase III RI field work for OU 1 is complete, and the 14-volume final RI report was delivered to EPA and the CDPHE on its extended milestone delivery date in June 1994. The OU 1 FS was completed in FY 95, with an evaluation of the list of remediation alternatives based on the revised interpretations of the nature and extent of contamination in the final RI. The final FS Report was submitted in February 1995. The final PP was submitted in May 1995. A ROD is expected to be signed in 1996.

The final draft and final OU 2 RI Reports were delivered to the regulatory agencies in May and September 1995, respectively. The OU 2 FS began in FY 95 but has been indefinitely deferred until funding is available. In lieu of the FS, two proposed action memorandums and one IM/IRA will be initiated in FY 96, with additional proposed action memorandums being completed in FY 97 and 98 . A no-action ROD is anticipated following completion of the accelerated actions.

In OU 3, Offsite Areas, the draft RI Report was completed and submitted to the regulators in October 1995. This assessment concludes that the risk from offsite contamination is below regulatory concern, and no remedial action is necessary. Following EPA and CDPHE review and comment incorporation, the final RI report is scheduled for approval in 1996.

Approximately 80 percent of the OU 4, Solar Evaporation Ponds, Phase I Assessment was completed in FY 94. Based on the 1993 dispute resolution with CDPHE and EPA, this degree of completeness was sufficient to proceed with development of the IM/TRA Decision Document for closure of the ponds. The Phase II RFIRI Work Plan was completed and approved by the regulatory agencies, and substantial progress was made on Phase II field work in FY 95. A draft IM/IRA decision document presenting a closure plan was submitted in February 1995.

The Phase I and Phase II RI field work for OU 5 were combined so that only one RI Report will be required, the draft of which will be delivered to the regulatory agencies in October 1995. A presumptive remedy will be used for remediation of the most contaminated sites in OU 5 , eliminating the need for the FS. If the Preble's Meadow jumping mouse, which has habitat in OU 5 and other 
buffer zone operable units, is added to the endangered species list as expected, field work in OU 5 may be delayed.

RI field work for OU 6 has been completed, and the RI Report is expected to be submitted in November 1995. The final report will be completed in FY 1996.

A proposal has been accepted by DOE, EPA, and CDPHE to consolidate operable units. Following completion of the OU 5 and OU 6 RI reports, these OUs will be combined with OU 2 and be named the Buffer Zone OU.

The two phases of OU 7 were combined with regulatory agency approval. This, along with use of a presumptive remedy to cap the present landfill, deleted 10 IAG milestones from this subproject. Design of a passive leachate collection system for the OU 7 present landfill was completed. OU 7 field work was completed in FY 95. A draft IM/IRA decision document was submitted in lieu of a draft ROD.

The field work for OUs 11 and 15 was completed. The final RI report for OU 11 was delivered in June 1995. The final RI report for OU 15 was delivered to the regulatory agencies in December 1994. No-action RODs were approved for these two operable units in September 1995.

Non-intrusive field work for OUs $8,9,10,12,13$, and 14, which are located within the RFETS industrial area, was placed under a stop-work order in March 1995. An orderly shutdown of field work was undertaken, which allowed certain seasonal sampling activities to continue. The stop-work order is still in effect, and no IAG milestones are being pursued. It is anticipated that the operable units within the industrial area will be reconfigured in the new Rocky Flats Cleanup Agreement or by a modification to the existing IAG, and current milestones will be replaced by new enforceable milestones. These OUs, OU 4, and those sections of OU 5 requiring cleanup will be consolidated into one Industrial Area OU.

Intrusive field work in the reconfigured industrial area operable units will not begin until the work is integrated with future decommissioning of facilities and other plant transition activities in this location. Coordination of all these activities will be addressed in the RFETS integrated planning process. Early cleanup or removal actions could occur for selected hot spots of concentrated contamination in these operable units if the need is identified.

A no-action ROD was proposed and has been approved for five of the original seven Individual Hazardous Substance Sites in OU 16. The other two Individual Hazardous Substance Sites were transferred to other operable units for further investigation, thereby completing all oU 16 activity.

In September 1993, the EPA and Rocky Flats Field Office presented a Superfund Innovative Technology Evaluation (SITE) demonstration. This demonstration included a general plant tour of RFETS and a viewing of the technology site, accompanied by a briefing about the SITE demonstration technology. The demonstration of the Colloid Polishing Filter Method technology conducted at RFETS showed removal efficiencies of up to 90 percent for uranium and 86.8 percent for gross alpha. The demonstration and results are discussed in several EPA publications available through the Office of Research and Development in Cincinnati, Ohio. 
The following public involvement activities were completed:

- Four quarterly public information meetings were held.

- The Technical Review Group continued to meet monthly to provide early public input on draft documents to the regulatory agencies.

- Monthly coordination meetings were held with EPA and CDPHE.

- All required documents were placed in RFETS public reading rooms and five other repositories.

- Tours, presentation, and briefings on various topics were presented to members of the public including the Rocky Flats Citizens Advisory Board and the Rocky Flats Local Impacts Initiative.

- There were three formal public comment periods on various documents as required by CERCLA.

- There were numerous updates on the Rocky Flats Cleanup Agreement, including a workshop which resulted in a list of community values and concerns which were used in the development of the document.

- A workshop was given for stakeholders on environmental laws and regulations. About 70 members of the public attended the day-and-a-half workshop.

\section{Progress in Conducting Remedial Actions}

After public comments and regulatory agency design approval, an IRA for OU 1 (a french drain groundwater collection system and Building 891 treatment facility) was constructed and placed into operation in May 1992. The OU 1 IRA treatment facility collected and treated over 4 million gallons of potentially contaminated groundwater through FY 95. Sampling has verified that contamination levels of the water being collected by the OU 1 IRA from the Building 881 footing drain is within acceptable limits, and authorization was granted by the regulatory agencies in 1994 to cease pumping this water to the french drain. This source accounted for 85 to 95 percent of the water treated by the OU 1 IRA. Several small radioactive hot spots were removed in September 1994. The primary source of groundwater contamination will be removed by excavation in FY 96 or FY 97, pending funding.

An IRA for OU 2 which collects, treats, and releases potentially contaminated surface water was completed and placed into operation in April 1992. The OU 2 IRA treatment facility has collected and treated over 24 million gallons of potentially contaminated surface water. Sampling has verified that the contamination level of the water being collected from two of the three surface water sources by the OU 2 IRA, which account for about 90 percent of the surface water collected, is within acceptable limits. Authorization to cease collection and treatment of water from these sources was granted by the regulatory agencies in 1994 for all but one location. The OU 1 and OU 2 water treatment plants were combined in FY 95 and will be used to treat all site groundwater in the future.

A second IRA for OU 2 was mandated by the regulatory agencies in FY 1991. The Phase I design of this IRA, which evaluated conventual vacuum-enhanced vapor extraction technology to extract volatile 
organics from vadose-zone soils, was approved by the regulatory agencies, and construction was completed in the first quarter of FY 94 . Approximately 915 pounds of volatile organic materials have been removed from the ground, processed, and disposed of. This IRA has now been canceled with approval of the regulatory agencies.

The Ryan's Pit removal action near Individual Hazardous Substance Site 109 was completed in FY 95. Approximately 200 cubic yards of contaminated soil were excavated and are awaiting treatment.

Construction of the Option B offsite water projects funded by DOE through grants to local municipalities continued through 1995. The Standley Lake Protection Project is nearly complete, and the City of Broomfield's new water treatment facility is expected to break ground in late 1995 . This new facility is expected to be fully operational in 1997.

RFETS is aggressively pursuing accelerated removal actions to reduce risks in a number of operable units. The removal of three "hot spots" (small volumes of soil with relatively high radioactive contamination) in OU I reduced the human health and ecological risk. Other accelerated actions, including removal of additional hot spots, storage tanks, and PCB-contaminated areas, were completed in FY 95.

During FY 94, procurement and certification of above-ground sludge storage tanks for the OU 4 solar ponds were completed. Upon certification of the tanks, sludge removal operations commenced in the unemptied solar evaporations ponds, utilizing commercially available vacuum tanker trucks. This operation proved to be extremely effective in removing sludge from the ponds, thereby minimizing further introduction of contaminants to the environment. Sludge removal operations were completed in early FY 95.

The OU 4 Interceptor Trench System was in operation throughout the year, collecting potentially contaminated near-surface groundwater and surface runoff. Nearly 2.5 million gallons were collected, stored in temporary holding tanks, and ultimately processed by two evaporative water treatment facilities located at the site. Due to high operational costs of the evaporator, a new passive water treatment plant to treat this water was proposed. Construction and use of the mobile treatment unit will begin in FY 96 or FY 97.

The OU 4 remediation methodology was modified several times during the fiscal year. The Draft Phase I Proposed IM/IRA Decision Document was delivered to regulatory agencies in May 1994 and included the proposed treatment scenario, which called for 1,000-year protection of the solar pond area below an engineered cap. The design was later modified to include disposition of specific remediation wastes that include minimally treated sludge from the ponds and failed pondcrete from earlier pond sludge remediation activities. A "path-forward" process has been established by DOE and the regulators to determine the final remedy for OU 4. A limited baseline risk assessment is being conducted to assist with the decision-making process.

Implementation of a wetlands mitigation effort in the area of the OU 1 french drain was completed in FY 94. Cattails, sedges, bulrush, three square, and willows were successfully planted on the 881 Hillside as a part of the revegetation plan after the area was lined with bentonite. Construction of the new wetlands was added to the original scope after it became evident that there would be a loss of some wetlands associated with the construction of the OU 1 IM/IRA french drain. Growth of the wetland vegetation was examined, and the regulatory agencies were pleased with the work accomplished. 
The final draft of the Pond Water Management IM/IRA was completed and submitted to CDPHE and EPA on November 23, 1993. The draft was required to be developed under the IAG by the regulatory agencies in 1992, even though there is no imminent hazard to public health or the environment from water on the plant site. The document went to dispute under the IAG; the parties met on April 15, 1994 and came to a resolution on dispute issues. DOE has not agreed with the use of CERCLA in lieu of the Clean Water Act to regulate surface waters; therefore, as part of the resolution, language addressing the designation of the ponds as "waters of the U.S." and preservation of DOE's rights to appeal this issue was included. A new pond operations plan, superseding the Pond Water IM/IRA, is expected to be submitted in December 1995 to DOE, EPA, and CDPHE. Pending approval, a new flow-through operations process will be implemented, with substantial cost savings.

\section{Enforcement Activities}

On July 7, 1994, a Rocky Flats Tolling (Settlement) Agreement was signed by the DOE Manager of RFETS and officials from the CDPHE and the EPA Region VIII. This agreement includes a settlement of $\$ 2,800,000$ for 14 missed or expected to be missed enforceable IAG milestones for the period of March 1993 through January 1995. This settlement payment includes cash payments of $\$ 350,000$ each to the CDPHE and the EPA, and \$2,100,000 in Supplemental Environmental Projects related to, at, or in the vicinity of RFETS. It is anticipated that a new Rocky Flats Cleanup Agreement will be negotiated and approved in 1996 . Milestones will be limited to a total of 12 per year for the entire site. The FY 96 milestones will be for excavation of two trenches in OU 2 and removal of the contents and cleaning of six tanks in the Industrial Area. 


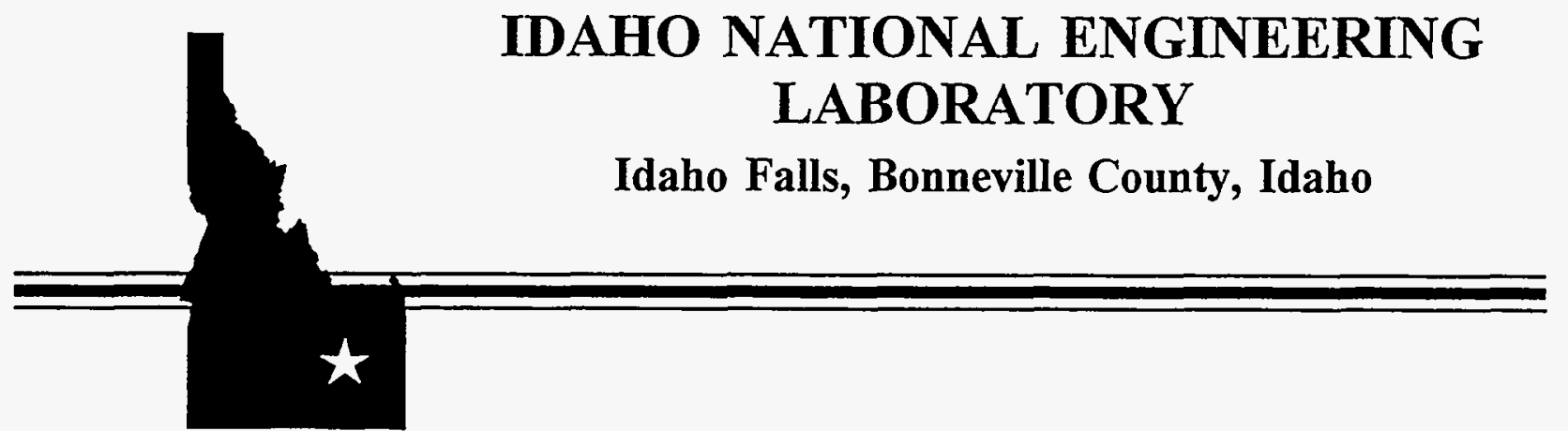

Progress in Reaching Interagency Agreement

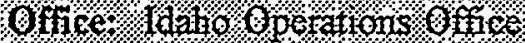

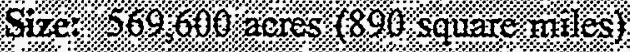

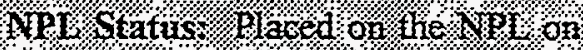

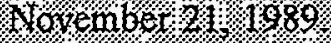

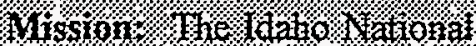

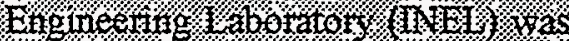

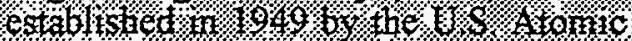

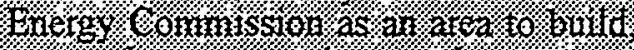
test: and operate ranions nutcerear:

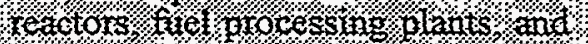

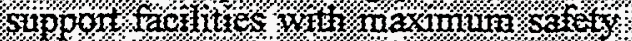

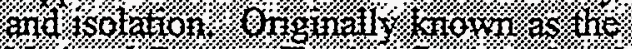

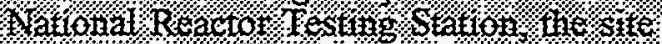

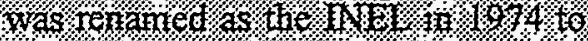

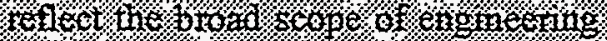

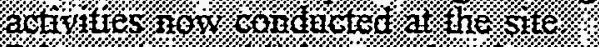

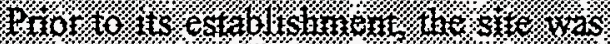

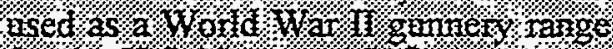

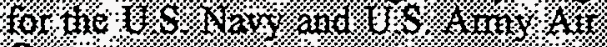
Co.ps:

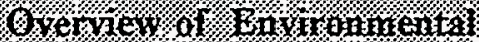

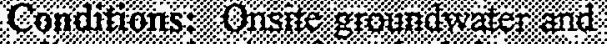

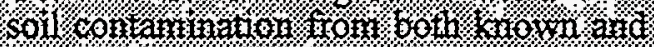

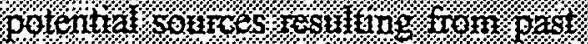

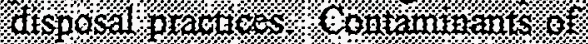

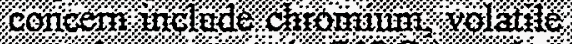

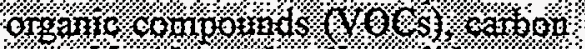

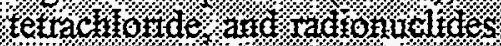

$$
\text { (1) }
$$

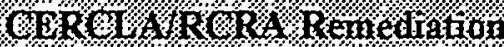

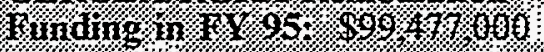

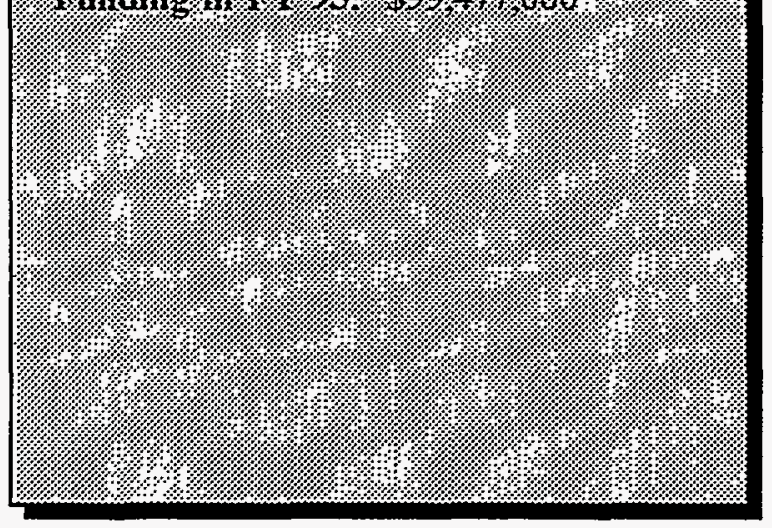

The INEL Federal Facility Agreement/Consent Order (FFA/CO) and Action Plan between DOE, EPA Region X, and the State of Idaho was executed on December 9, 1991. The FFA/CO supersedes the RCRA 3008(h) Consent Order and Compliance Agreement (COCA) and covers all CERCLA response requirements as well as RCRA corrective action requirements. All parties agreed to initiate the FFA/CO Action Plan under the COCA in September 1991 while the FFA/CO was being finalized. The FFA/CO also includes Argonne National Laboratory (ANL) - West and the Naval Reactors Facility (NRF), which are located at INEL.

Specific Cost Estimates and Budgetary Proposals Involved in Each Interagency Agreement

Funds budgeted for environmental restoration under the IAG Action Plan at the INEL total \$87.4 million of appropriated funding for FY 96 and $\$ 101$ million for FY 97 according to the request in the President's Budget.

\section{Public Comments Regarding Interagency Agreements}

No new public comments concerning the IAG were received in FY 95. The Community Relations Plan was finished and released; INEL hosted five informal scoping periods, three public meetings, and five open houses. 
Progress in Conducting Remedial Investigations/Feasibility Studies

$\underline{\text { INEL }}$

In FY 95, one RI/FS Statement of Work for remediation of the Test Area North was submitted; RU/FS Work Plans for remediation of the Idaho Chemical Processing Plant, Test Reactor Area, Test Area North, and Radioactive Waste Management Complex were submitted; and an RI/FS Report and Proposed Plan for Stationary Low Power Reactor-1 (SL-1) and Boiling Water Reactor Experiment Reactor (BORAX-1) burial grounds were completed.

The following are documents that were developed and submitted to EPA and the State of Idaho during FY 95 at the INEL, plus associated activities:

- Draft RI/FS Statement of Work and Work Plan for Comprehensive RI/FS (OU 1-10);

- Draft Test Area North Groundwater Draft Final RD/RA Statement of Work (OU 1-07B);

- Draft Final RA Report for Test Area North Groundwater (OU 1-07B);

- $\quad$ ROD for Test Area North Groundwater (OU 1-07B) (signed);

- Statement of Work and Work Plan for Test Area North Comprehensive RU/FS;

- Draft Final RI/FS Report Test for Area North Groundwater (OU 1-07B);

- $\quad$ Comprehensive RI/FS Statement of Work and Work Plan for OU 1-10;

- Draft Test Reactor Area Comprehensive RI/FS Scope of Work (OU 2-13);

- Data Transmittal Package (four rounds of data transmittal) Test Reactor Area Perched Water (OU 2-12);

- WAG 2 Comprehensive RI/FS Work Plan submitted to agencies (OU 2-13);

- $\quad$ RAD Soils Treatability Study Report, RI/FS Scope of Work and Work Plan for the Idaho Chemical Processing Plant finalized (OU 3-13);

- $\quad$ RI/FS Sampling completed for WAG 3 Comprehensive RI/FS (OU 3-13);

- RI/FS Comprehensive Work Plan;

- Draft Final RI/FS Report for Central Facilities Area Landfills (OU 4-12);

- $\quad$ Final ROD for Central Facilities Area Landfills (OU 4-12) (signed);

- Draft RI/FS PP for Central Facilities Area Landfills (OU 4-12);

- $\quad$ RI/FS Report and PP for the Auxiliary Reactor Area (ARA)

SL-1 Burial Ground (OU 5-05) and BORAX-1 Burial Site (OU 6-01); 
- Draft RI/FS ROD for ARA SL-1 Burial Ground (OU 5-05) and BORAX-1 Burial Site (OU 6-01);

- Draft Final RA Report for the Power Burst Facility Evaporation Pond (OU 5-13);

- Phase I Draft Preliminary Design for Organic Contamination in the Vadoze Zone (OU 7-08);

- Phase I RD/RA Work Plan for Organic Contamination in the Vadoze Zone (OU 7-08);

- $\quad \mathrm{RD} / \mathrm{RA}$ Statement of Work for Organic Contamination in the Vadose Zone (OU 7-08) (finalized);

- $\quad$ Pit 9 Draft Explanation of Significant Differences Report (OU 7-10);

- $\quad$ Pit 9 Final RD/RA Scope of Work (OU 7-10);

- $\quad$ Pit 9 Treatment System Process (90\%) Design (OU 7-10);

- Pit 9 Overburden Sampling and Analysis Plan and Health and Safety Plan (OU 7-10);

- Pit 9 90\% Design for Retrieval, Treatment, and Support Facilities/Systems (OU 7-10);

- $\quad$ Final RA Report for Pad A (OU 7-12) (finalized);

- Draft RI/FS Scope of Work Plan for Comprehensive RI/FS (OU 7-13/14);

- $\quad$ ROD for Industrial Waste Ditch (OU 8-07) and NRF Inactive Landfills (OU 8-05/06);

- NRF Inactive Landfills RD/RA Scope of Work (OU 8-05/06);

- NRF Inactive Landfills RD Report and RA Work Plan (OU 8-05/06);

- $\quad$ Scope of Work for the Comprehensive RI/FS (OU 8-08) and;

- Work Plan for the Comprehensive RU/RS (OU 8-08).

\section{$\underline{\text { ANL-West }}$}

The Draft RI/FS Statement of Work for ANL-West was completed in FY 95.

The following are documents that were developed and submitted to EPA and the State of Idaho during FY 95 for ANL-West, plus associated activities:

- Draft RI Scope of Work; and

- Draft RI Work Plan elements. 


\section{Progress in Conducting Remedial Actions}

Thirty No Further Action determinations were approved following the guidance outlined in the FFA/CO.

\section{INEL}

The following activities were accomplished in FY 95 at the INEL:

\section{Assessment}

- 18 of 24 RODs complete or underway;

- $\quad$ Completed 38 assessment, extraction, and monitoring wells (cumulative depth over 8,500 feet);

- Submitted the Radionuclide Contaminated Soils Draft RIFS Report (OU 10-06) to the EPA and the State of Idaho; and

- Completed INEL Ecological Risk Assessment Guidance Manual and all WAG specific screening level ecological risk assessments.

\section{Cleanup}

- Removal Action - Test Area North Injection Well Site (OU 1-07A) processed 357,000 gallons of water from the Snake River Plain Aquifer and removed 3,000 pounds of organic waste trichloroethylene/perchloroethylene;

- Interim Action - Completed excavation of 240 cubic yards of calcine-contaminated soil (mercury contamination) from Central Facilities Area Pond site (OU 4-05);

- Interim Action - Completed excavation, boxing, and disposal of 285 cubic yards of hazardous, radioactive soil from Power Burst Facility Evaporation Pond site (OU 5-13, chromium and low levels of cesium);

- Radionuclide-contaminated soil removal conducted at six OU 10 sites;

- $\quad$ Pad A - Long Term Monitoring Plan finalized;

- Completed remedial action at Pad A;

- Removal Action - Three 16-inch shells, 24 pounds of RDX explosive material, and 55,000 pounds of scrap metal removed from ordnance sites (OU 10-03). The explosive ordnance waste will continue to be disposed of at INEL in the Central Facilities Area landfill following detonation and approved certification. This represents 22 acres of Removal Action;

- Power Burst Facility Reactor Area Evaporation Pond Site Reclamation activities completed August 22, 1995;

- $\quad$ Army Re-entry Vehicle Facility Storage (ARVFS) NaK safely moved to ANL-West; 
- Removed five french drains at the 4-09 Removal Action; and

- Began treatment of the ARVFS NaK. Projected completion of treatment is February 1996. Final stabilization is scheduled by the end of March 1996.

\section{$\underline{\text { ANL-West }}$}

The following activities were accomplished in FY 95 at ANL-West:

\section{$\underline{\text { Assessment }}$}

- Completed accelerated pre-RI characterization for all release sites.

\section{Cleanup}

- Completed removal of 250 feet of contaminated liquid waste pipeline. 
This Page Intentionally Left Blank. 


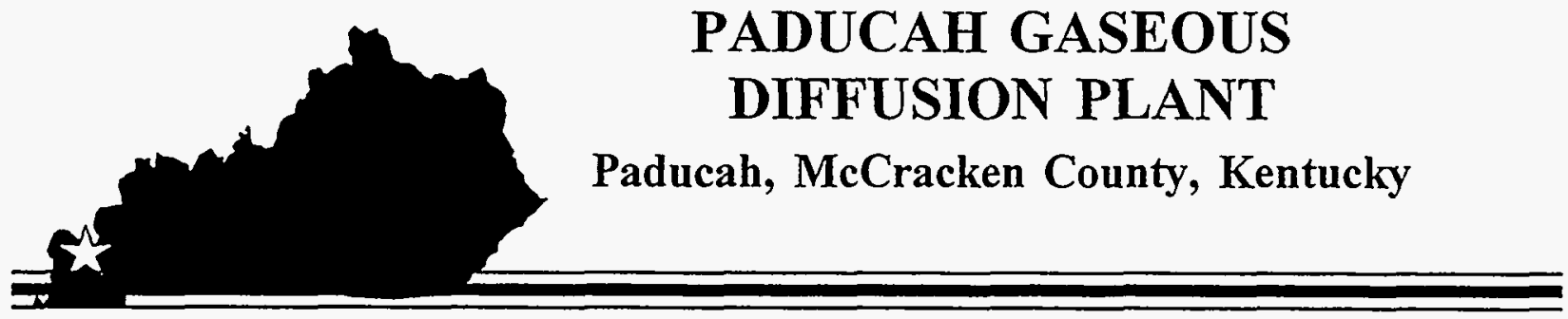

Office: Oakt Ridge Operations Office

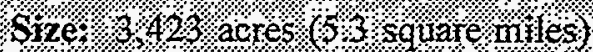

Nul Status: Dlaced on the Vat on $113 \times 9.1 .094$.

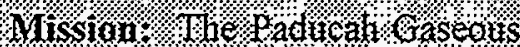

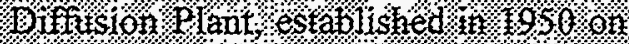

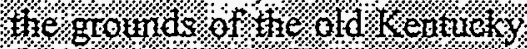

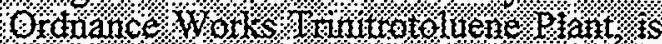

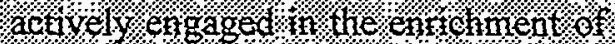

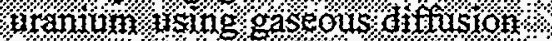

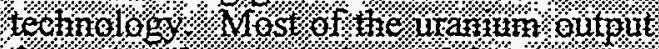

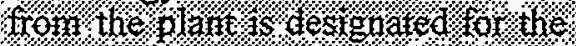

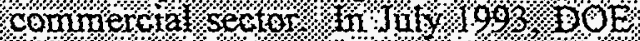

offierativ transferedintesponstivility for

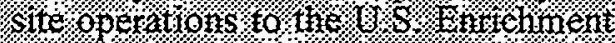

Qorpooration in aceordance with the

Fitergy. Polloy, oct of 1992 .

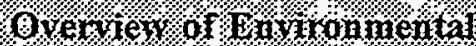

Conditions: 1.1. Site contsists of 2014

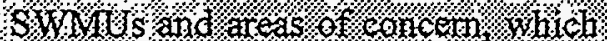

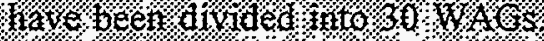

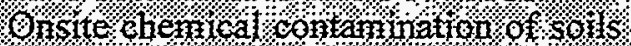

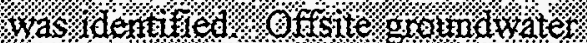

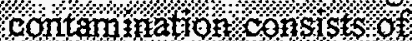

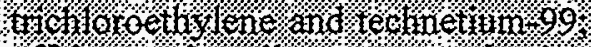

offsite creed sediminent o ontandination

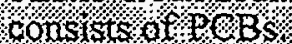

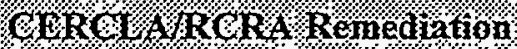

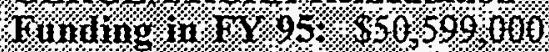

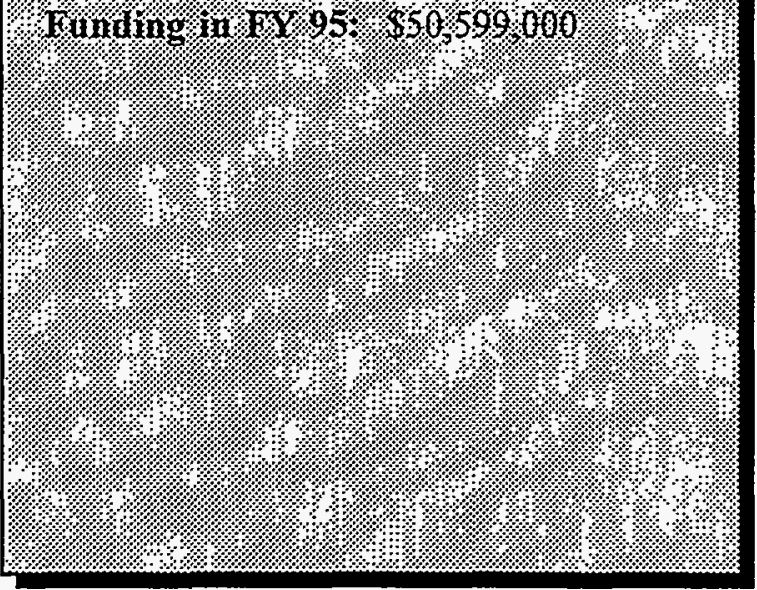

\section{Progress in Reaching Interagency Agreements}

Although Paducah Gaseous Diffusion Plant is listed on the NPL, remediation is currently being addressed under authority of a RCRA 3008(h) Administrative Consent Order that was signed November 4, 1988, and a RCRA Part B Permit (referred to as a Hazardous and Solid Waste Amendments permit) that was jointly issued by EPA and the State of Kentucky on July 16, 1991. DOE is working with EPA and the state to develop an IAG; while negotiations are still underway, DOE expects the agreement to be signed in 1996.

\section{Specific Cost Estimates and Budgetary Proposals Involved in Each Interagency Agreement}

Funds budgeted for environmental restoration at Paducah Gaseous Diffusion Plant total $\$ 45.8$ million of appropriated funding for FY 96 and $\$ 32.4$ million for FY 97 according to the request in the President's Budget.

\section{Public Comments Regarding Interagency Agreements}

Because the IAG is currently under development, the public has not commented on the IAG.

\section{Progress in Conducting Remedial Investigations/Feasibility Studies}

The Administrative Consent Order for Paducah Gaseous Diffusion Plant was executed by DOE and EPA on November 4, 1988. The RCRA Part B Permit with EPA and the State of Kentucky was 
executed on July 16, 1991. During FY 95, work completed or underway at Paducah Gaseous Diffusion Plant was as follows:

- $\quad$ Completed treatability study for WAG 23 PCB spill sites;

- Submittal and signing of the WAG 22 Burial Grounds (SMWUs 2 and 3) interim action ROD;

- Submittal and signing of northeast plume interim action ROD;

- $\quad$ Continued water policy and submitted the Post Construction Report;

- Continued sampling of approximately 140 groundwater monitoring wells and 30 residential wells;

- Submittal of two RI workplans (WAG 6 and WAG 17), one RI addendum (WAG 23), one preliminary characterization and study report (northeast plume), and two operation and management plans (northwest plume and north/south diversion ditch);

- Continued negotiation of the FFA;

- Continued development of the waste management strategy and site treatment plan; and

- Completed the WAG 1 and WAG 7 RI Report and began the development of the FS.

\section{Progress in Conducting Remedial Actions}

During FY 95, the following work was completed or underway at Paducah Gaseous Diffusion Plant:

- Completed construction of northwest Plume Treatment Facility. The facility became operational in September 1995;

- Completed construction of the North/South Diversion Ditch Interim Action; and

- Continued development of dense nonaqueous phase liquid technology and completed construction of a decontamination pad and field support laboratory to support all remedial action projects.

All of this work is being conducted under individual RODs. The Paducah site is currently negotiating an FFA that would direct overall remedial work. 


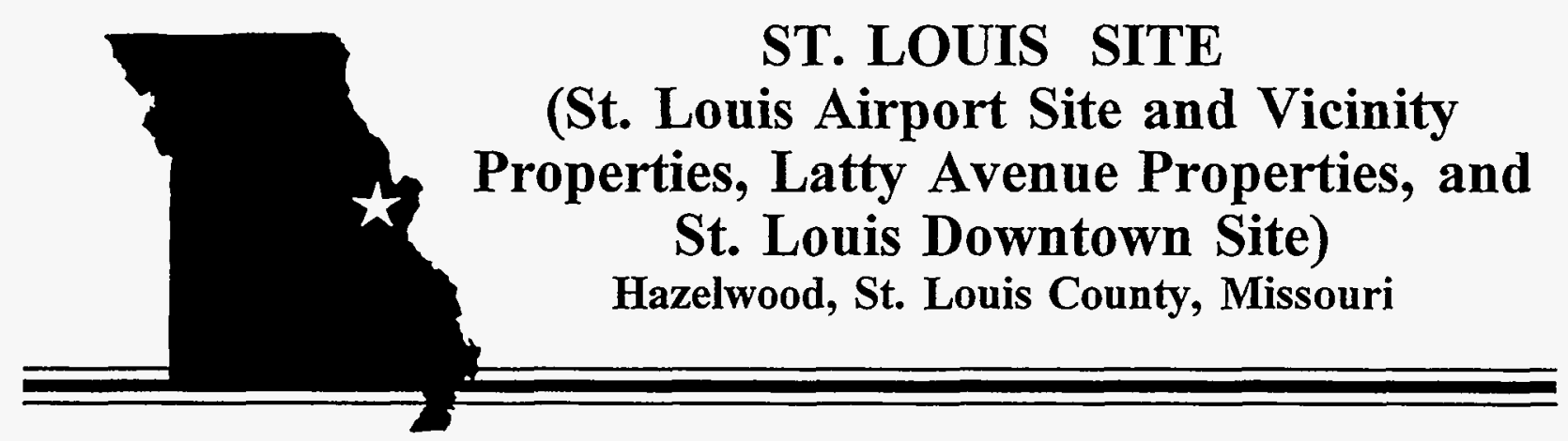

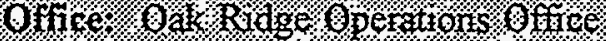

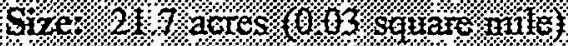

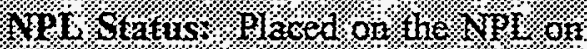

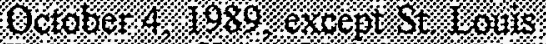

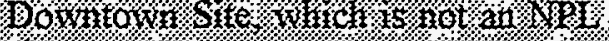
site.

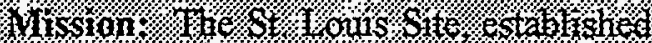

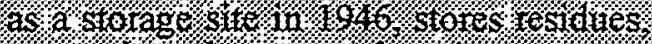

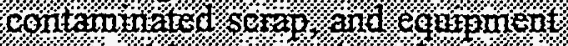

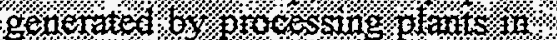

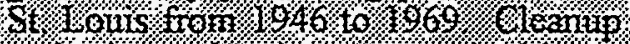

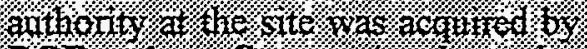

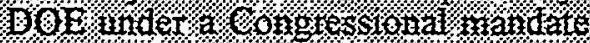

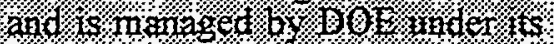

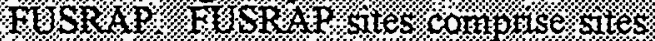

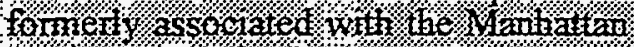

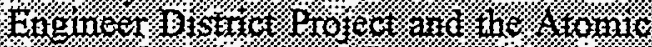

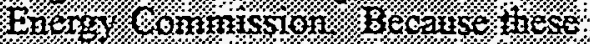

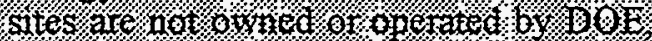

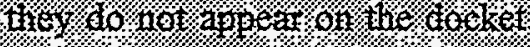

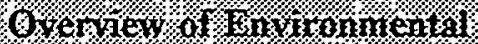
Conititions. OOnsite solis and

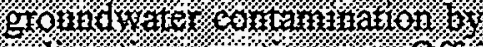

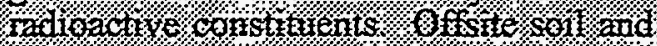

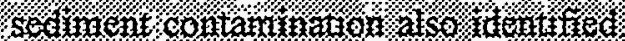

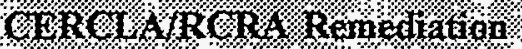

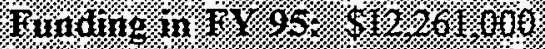

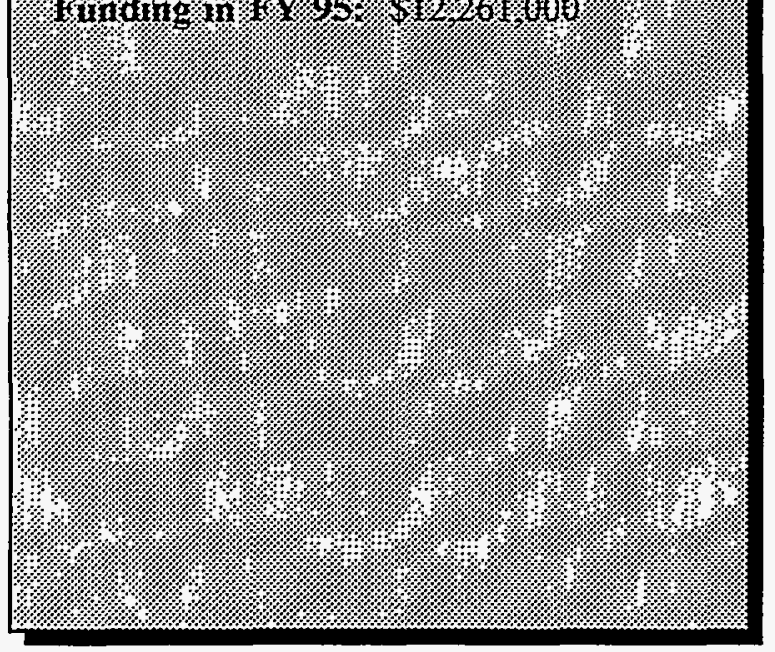

Progress in Reaching Interagency Agreement

DOE and EPA Region VII executed an FFA for the St. Louis Site on June 26, 1990. The St. Louis Site consists of the St. Louis Airport Site and Vicinity Properties, and Latty Avenue Properties, all of which were added to EPA's NPL in October 1989. An additional site, not included in the original 1989 NPL, is being addressed in accordance with requirements stipulated in the FFA to make the remediation process more efficient. This site, identified as the St. Louis Downtown Site, is now part of DOE's FUSRAP program.

\section{Specific Cost Estimates and Budgetary Proposals Involved in Each Interagency Agreement}

Funds budgeted for environmental restoration under the FFA total \$14.I million of appropriated funding for FY 96 and \$13.6 million for FY 97 according to the request in the President's Budget.

\section{Public Comments Regarding Interagency Agreements}

No new public comments regarding the FFA were received in FY 95.

\section{Progress in Conducting Remedial Investigations/Feasibility Studies}

The RI/FS work plan for the St. Louis Site was approved by EPA Region VII in calendar year 1991. A public scoping meeting for the preparation of an RI/FS was held in January 1992. An RI report was approved by EPA Region VII in 1992. Some limited additional field investigation was performed in FY 92 to supplement the existing characterization data. The Initial Screening of Alternatives was approved by EPA Region VII in FY 92. Based on 
the results of the Initial Screening of Altematives, an FS was prepared and issued for review to EPA Region VII and the State of Missouri in FY 93.

EPA has delayed final approval of the FS, and DOE has agreed to reconsider the remedy selection proposed in the draft proposed plan. EPA and DOE have agreed to defer the ROD in order to solicit input from a St. Louis stakeholder group. This group, named the St. Louis Site Citizens Task Force, was established in September 1994. It consists of elected officials, state and Federal regulators, public health officials, utility and business representatives, and interested citizens.

\section{Progress in Conducting Remedial Actions}

Final remedial action will be implemented following signing of the ROD. Proposals for interim cleanup measures have been made for properties in the vicinity of the St. Louis Airport Site. Six privately owned vicinity properties and two industrial properties have been cleaned up in FY 95 . Interim cleanup measures have been completed (the size of one city block) at the St. Louis Downtown Site to accommodate site infrastructure work conducted by the site owner, Mallinckrodt Incorporated. 


\title{
WELDON SPRING SITE REMEDIAL ACTION PROJECT
}

\author{
St. Charles County, Missouri
}

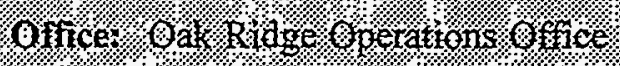

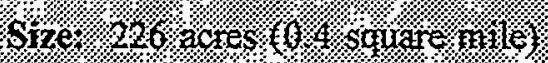

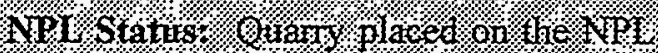

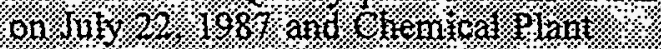

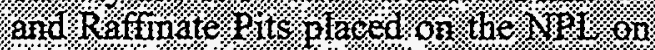

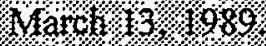

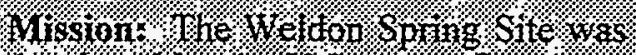

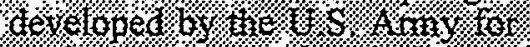

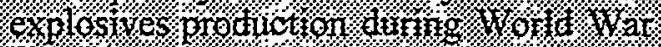

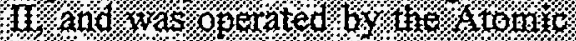

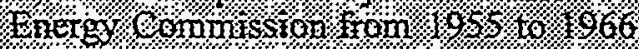

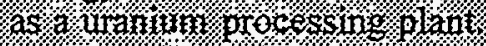

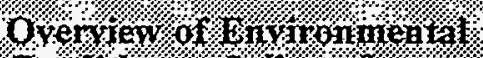

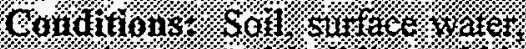

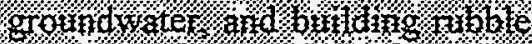

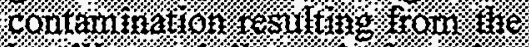

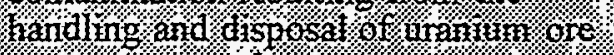
concentivtes.and Sorap.

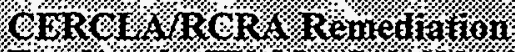

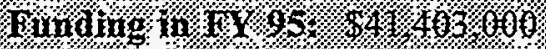

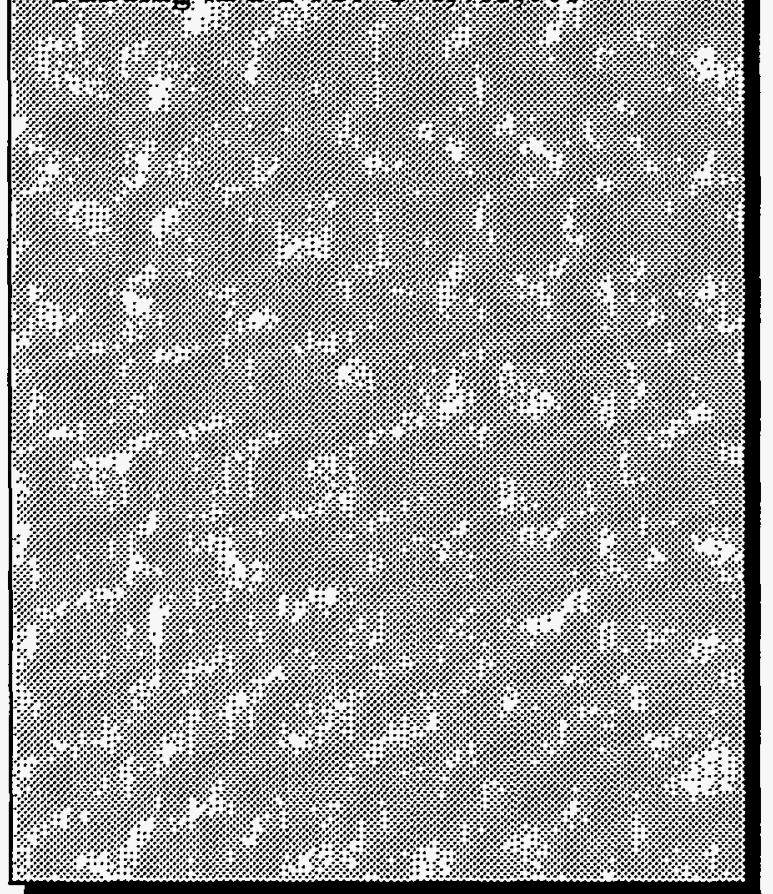

\section{Progress in Reaching Interagency Agreement}

DOE and EPA Region VII entered into an FFA, signed on August 12,1986. An amended FFA was signed on June 30, 1992.

\section{Specific Cost Estimates and Budgetary Proposals Involved in Each Interagency Agreement}

Funds budgeted for environmental restoration under the FFA at the site total $\$ 58.5$ million of appropriated funding for FY 96 and $\$ 67.5$ million for FY 97 according to the request in the President's Budget.

\section{Public Comments Regarding Interagency Agreements}

The public comment period for the FFA began on March 22, 1992 and remained open for 45 days. No comments were received during this period.

\section{Progress in Conducting Remedial Investigations/Feasibility Studies}

Initial work was started under a CERCLANNEPA FFCA executed in 1986. Subsequently, the site was placed on the NPL in July 1987. The Weldon Spring Site project issued a work plan in August 1988 which presented the overall strategy for accomplishing remedial actions. That strategy included the development of an umbrella RI/FS for the Chemical Plant Area, an RU/FS for Quarry bulk wastes, an RI/FS for Quarry residuals, and several interim response actions. A need was subsequently identified to specifically address groundwater at the Chemical Plant Area through an additional RI/FS. 
Major accomplishments in FY 95 include:

- Completed the joint RA Work Plan for the Site Groundwater Operable Unit with the Department of the Army in May 1995.

- $\quad$ Completed the Site Groundwater Sampling Plan in August 1995.

\section{Progress in Conducting Remedial Actions}

Remedial actions accomplished during FY 95 include:

- Completed construction and initiated testing of the Pilot Sludge Processing Facility in December 1994.

- Completed acquisition of 2 million cubic yards of soil in the Soil Borrow Area from the State of Missouri in July 1995. This Area will be utilized during disposal facility construction.

- Demolished the last 4 buildings in the demolition packages in December 1994. To date, 43 of the 44 buildings have been demolished.

- As of September 1995, treated a total of 100 million gallons of water at the Quarry Water Treatment Plant and Site Water Treatment Plant.

- Completed excavation of 72,883 cubic yards in the Quarry bulk waste removal effort in September 1995, for a cumulative excavated volume of 116,000 cubic yards (approximately 96 percent of the total anticipated volume).

- Expect to complete construction of the Site Water Treatment Plant-Train 2 facilities in October 1995. 


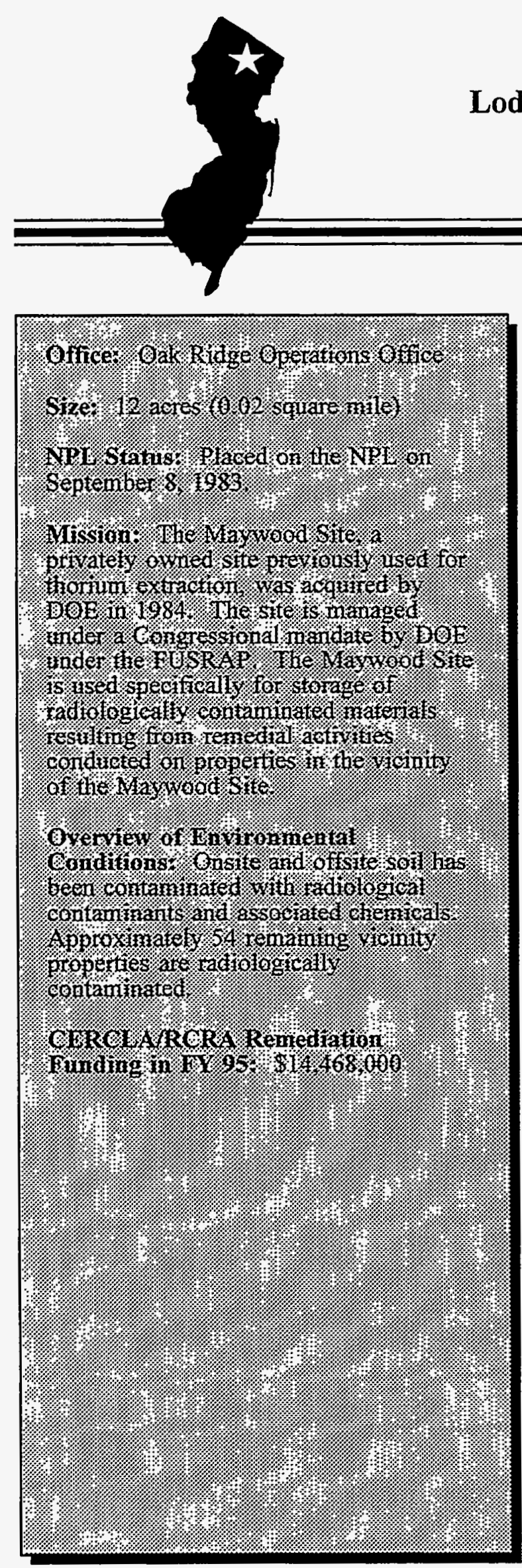

MAYWOOD SITE

Maywood/Rochelle Park/

Lodi, Bergen County, New Jersey

\section{Progress in Reaching Interagency Agreement}

An FFA for the Maywood Site, signed by EPA Region II and DOE on July 23, 1990, became effective in April 1991. Schedules were subsequently negotiated for the DOE submittal of the $\mathrm{RI}$, the baseline risk assessment, and the FS. EPA Region II reviewed and approved the package on November 25, 1991.

\section{Specific Cost Estimates and Budgetary Proposals Involved in Each Interagency Agreement}

Funds budgeted for environmental restoration under the FFA total $\$ 15.9$ million of appropriated funding for FY 96 and $\$ 15.9$ million for FY 97 according to the request in the President's Budget.

\section{Public Comments Regarding Interagency Agreements}

No new public comments regarding the FFA were received in FY 95.

\section{Progress in Conducting Remedial Investigations/Feasibility Studies}

Significant progress was made in FY 95 on the completion of RU/FS activities at the site. The Final Draft FS Report was issued in April 1994. Comments on the PP were provided by EPA Region II in September 1995. The PP is expected to be released to the public in FY 97 pending the resolution of specific issues. 


\section{Progress in Conducting Remedial Actions}

Substantial progress has been made using removal actions. The site consists of the DOE-owned Maywood Interim Storage Site and vicinity properties, all of which are contaminated. As of May 1986, 25 of the vicinity properties were cleaned up using removal actions, and the resulting waste was placed in storage in the engineered cell at the Maywood Interim Storage Site. During FY 94, a dispute with EPA over cleanup criteria was resolved and agreement was reached with the State of New Jersey on the cleanup criteria for residential properties. Removal of the Maywood Interim Storage Site Pile began in 1995, and approximately $40 \%$ of the waste has been removed. Completion of the Maywood pile removal is scheduled for FY 97. Remedial action continued at selected vicinity properties. Five contaminated vicinity properties were released back to the landowner for unrestricted use. Remedial actions are expected to continue at vicinity properties in FY 96. 


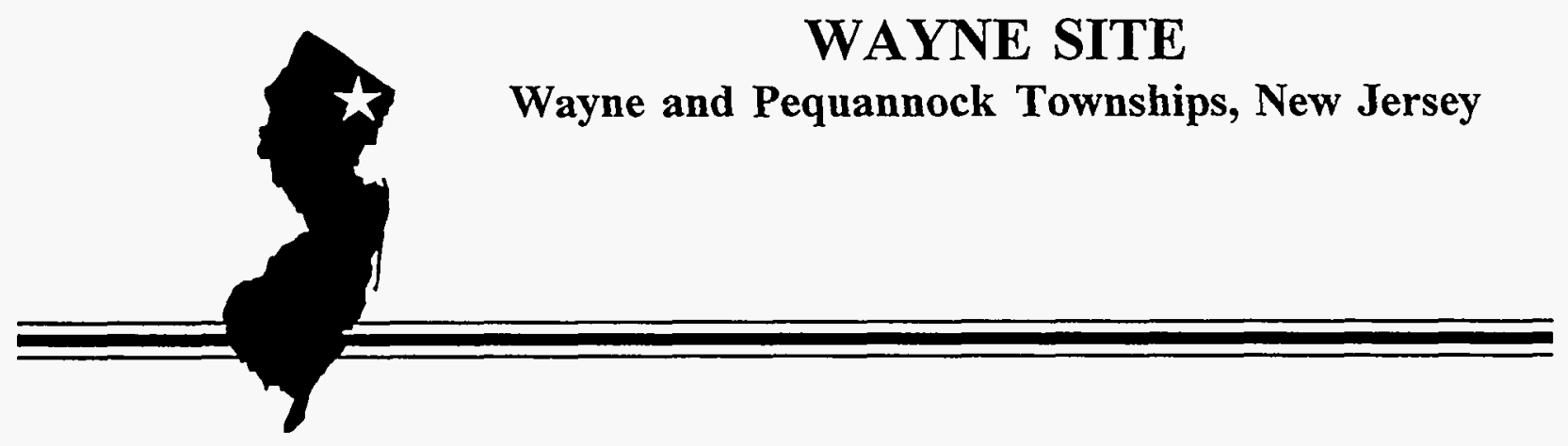

Progress in Reaching Interagency Agreement

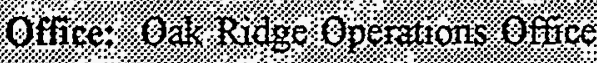

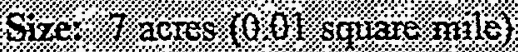

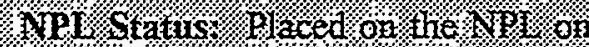

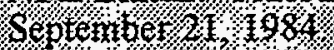

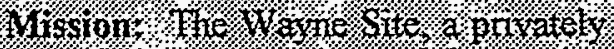

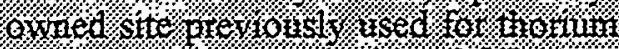

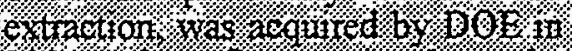

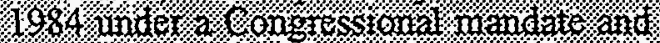

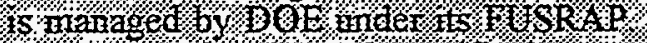

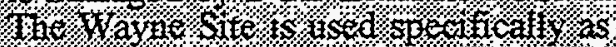
an interin s torage: site for centaniniated:

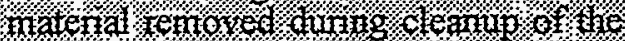

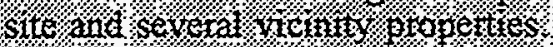

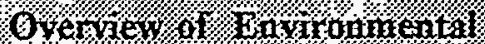
Conditions: Onsite soil contizininated

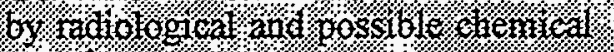
constititinis:

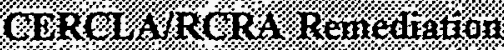

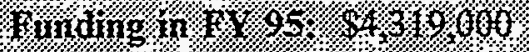

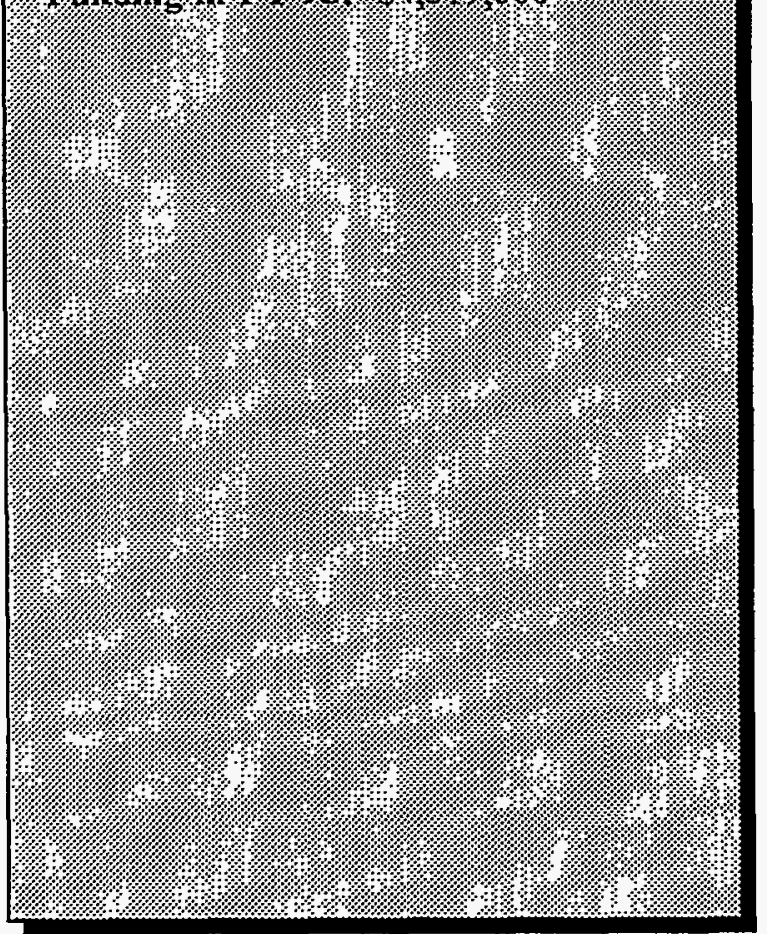

An FFA for the Wayne Site, signed by EPA on July 17, 1990 and by DOE on July 23, 1990, became effective in April 1991. Schedules were subsequently negotiated for the submittal of the RI, the baseline risk assessment, and the FS reports.

EPA Region II reviewed and approved the package on November 25, 1991.

\section{Specific Cost Estimates and Budgetary Proposals Involved in Each Interagency Agreement}

Funds budgeted for environmental restoration under the FFA total $\$ 6.1$ million of appropriated funding for FY 96 and $\$ 6.1$ million for FY 97 according to the request in the President's Budget.

\section{Public Comments Regarding Proposed Interagency Agreements}

No new public comments regarding the FFA were received in FY 95.

\section{Progress in Conducting Remedial Investigations/Feasibility Studies}

Significant progress was made during FY 95 on the completion of RI/FS activities at the site. To date, DOE has met all RI/FS milestones specified in the FFA. DOE continues to operate a public information center at the site to provide information on RI/FS progress.

The RI report for the Wayne Site was issued in October 1993. The Baseline Risk Assessment Report was finalized in January 1994. The EPA Final Draft FS Report was issued in March 1994. 
A PP was developed, comments were received from EPA Region II in September 1995, and the PP will be released for public comment in FY 96.

\section{Progress in Conducting Remedial Actions}

Earlier removal actions at the site entailed removing waste from the vicinity properties and storing it in an engineered waste storage pile at the Wayne Interim Storage Site. In FY 94, all remaining vicinity properties at the Wayne Site were remediated. A non-time-critical removal action was initiated in FY 95 to ship contaminated material from the interim storage pile to a commercial disposal facility in Utah. 


\section{BROOKHAVEN NATIONAL LABORATORY Upton, Suffolk County, New York}

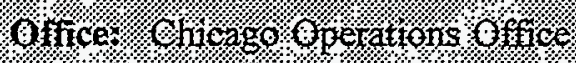

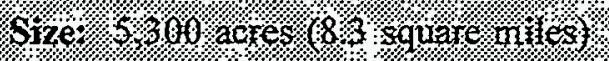

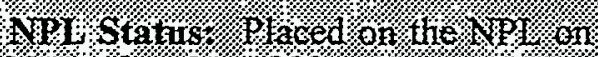

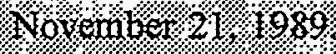

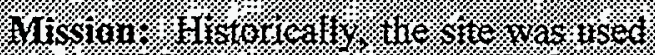

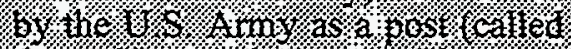

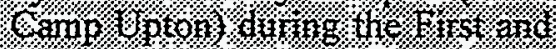

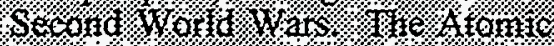

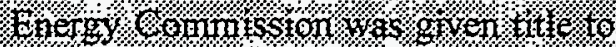

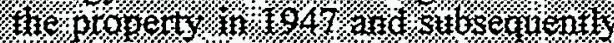

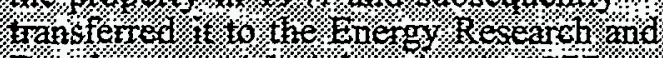

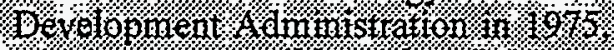

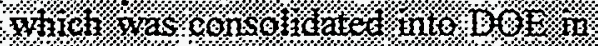
$10 \%$

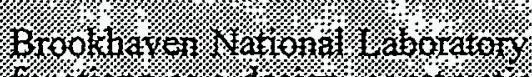

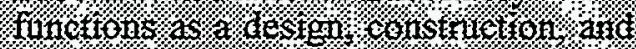

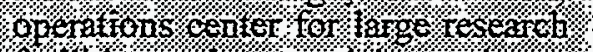

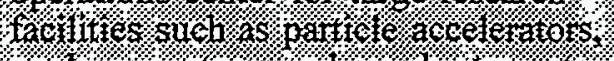

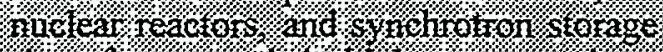

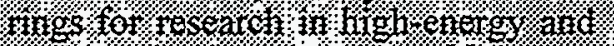

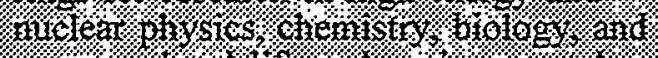

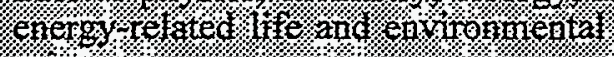
sctences:

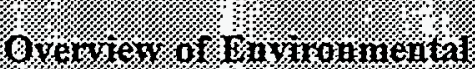

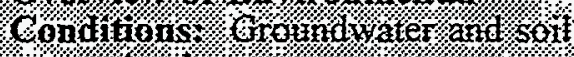
contiannitatition:

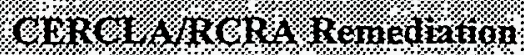

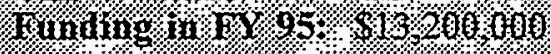

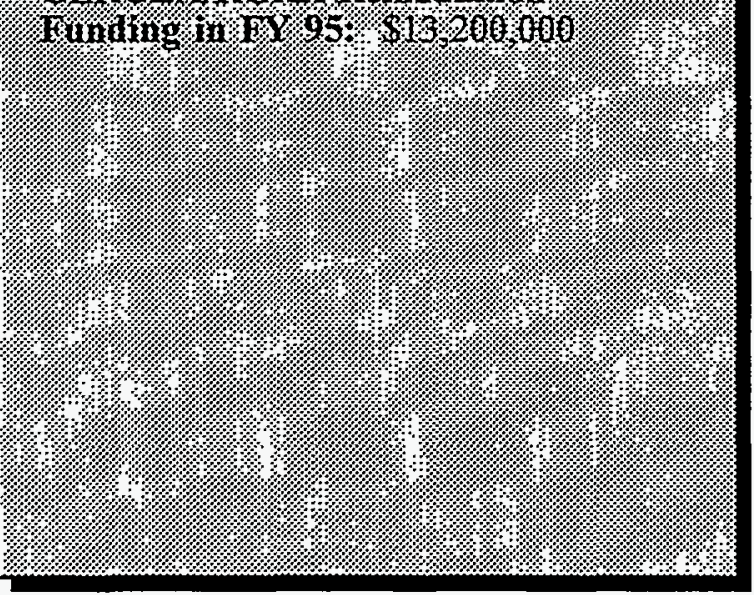

\section{Progress in Reaching Interagency Agreement}

DOE, EPA Region II, and the State of New York executed the IAG for Brookhaven National Laboratory on February 28, 1992. The effective date of the agreement was May 27, 1992. The IAG integrates both corrective action requirements under RCRA and response action requirements under CERCLA.

\section{Specific Cost Estimates and Budgetary Proposals Involved in Each Interagency Agreement}

Funds budgeted for environmental restoration under the IAG at the Brookhaven National Laboratory total $\$ 20.0$ million of appropriated funding for FY 96 and $\$ 20.0$ million for FY 97 according to the request in the President's Budget.

\section{Public Comments Regarding Interagency Agreements}

No new public comments regarding the IAG were received in FY 95.

\section{Progress in Conducting Remedial \\ Investigations/Feasibility Studies}

In FY 94, DOE received approval from the regulators to combine some of the seven OUs for greater efficiency and cost-effectiveness. OUs II and VII were combined, as were OUs I and VI. Each of the five OUs will undergo an RI/FS. Six removal actions also have been identified. An annual schedule document is required under the IAG to be submitted to the regulators.

Field work for OU IV was completed in 1993 and the draft RI and Risk Assessment Reports were submitted to EPA Region II and the State of New 
York on May 25, 1994 for review and comment. The draft Work Plans for OUs V and III were submitted October 29, 1993 and June 30, 1994, respectively, and were subsequently approved.

Scoping activities were conducted for OU II/VII during FY 94, and Work Plan preparation began in August 1994.

Field work for OU I and the Spray Aeration was completed with the exception of the second round of groundwater sampling. The Work Plan for OU VI, which was prepared as an addendum to the OU I plans, was finalized in June 1994, and field work was conducted in FY 95.

In FY 95, the following major documents were submitted to EPA and the State of New York:

- OU I RU/RA;

- OU II/VII RI/FS Work Plan;

- $\quad$ OU IV FS draft PP, and draft ROD; and

- Groundwater removal action draft EE/CA and Action Memorandum.

\section{Progress in Conducting Remedial Actions}

Four underground storage tanks were removed at Building 650 in August 1994, and a draft Completion Report was prepared. Characterization work for the Landfills Removal Action was completed, and a draft EE/CA was submitted to EPA Region II and the State of New York on July 28, 1994. Preparation of the design for the Current Landfills Cap began in FY 94, and the draft Design/Closure Report was submitted on July 25, 1994. A contractor was selected for the D Tanks removal action and mobilization occurred in July 1994. Dismantlement of the tanks started on September 14, 1994. Draft Designs for the Cesspool Removal Action were submitted in August 1994. The Building 464 soil removal action was completed in December 1993.

In FY 95, the following remedial actions occurred:

- Twenty-three cesspool removals were completed;

- Four underground storage tanks were cut and packaged and the waste shipped offsite;

- D-Tanks removal was completed; and

- $\quad$ Landfill capping was initiated and is expected to be completed in early FY 96.

\section{$\underline{\text { Enforcement Activities }}$}

A $\$ 100,000$ assessment of penalties under RCRA/Toxic Substances Control Act (TSCA) was pending throughout 1992 and 1993. A settlement of $\$ 62,000$ was reached in the spring of 1994. On May 11, 1994, DOE, EPA, and the operating contractor (Associated Universities Incorporated) signed an agreement on the penalty, which also included preparation of a Wildlife Survey and Management Plan and an internal audit of the hazardous waste management system. These activities are expected to be completed in FY 95. 


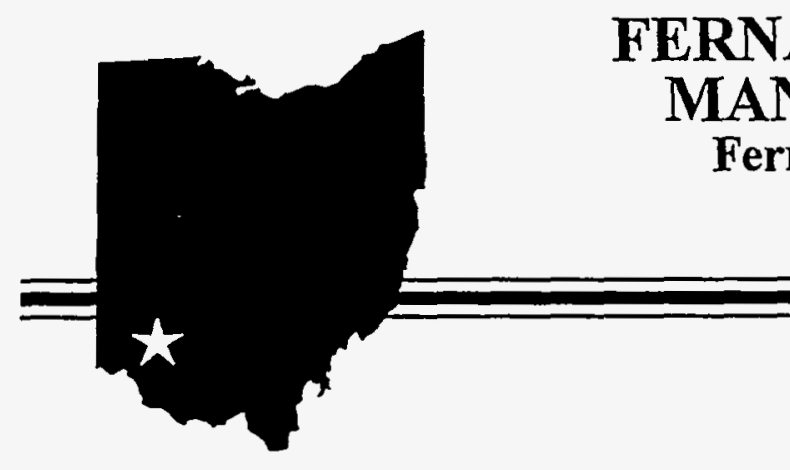

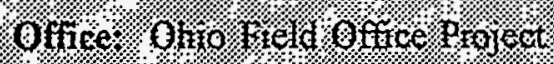

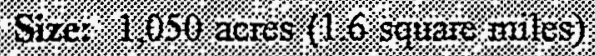

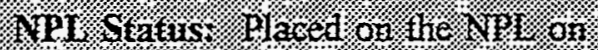

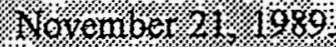

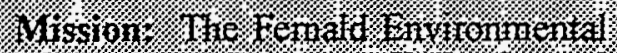

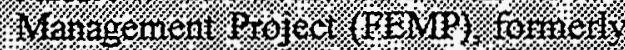

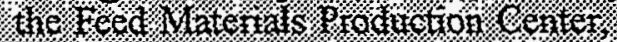

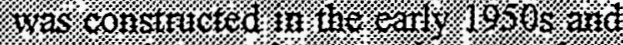

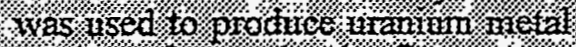

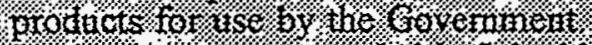

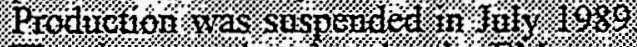

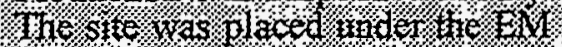

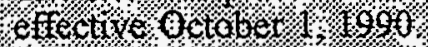

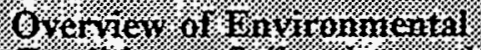

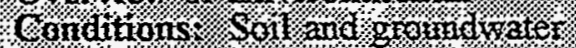

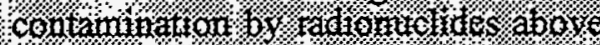

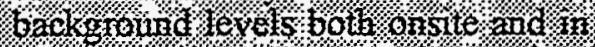

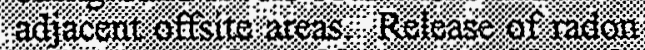

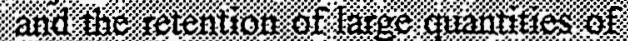

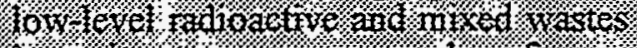

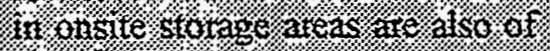

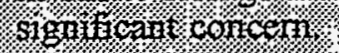

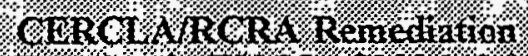

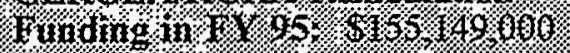

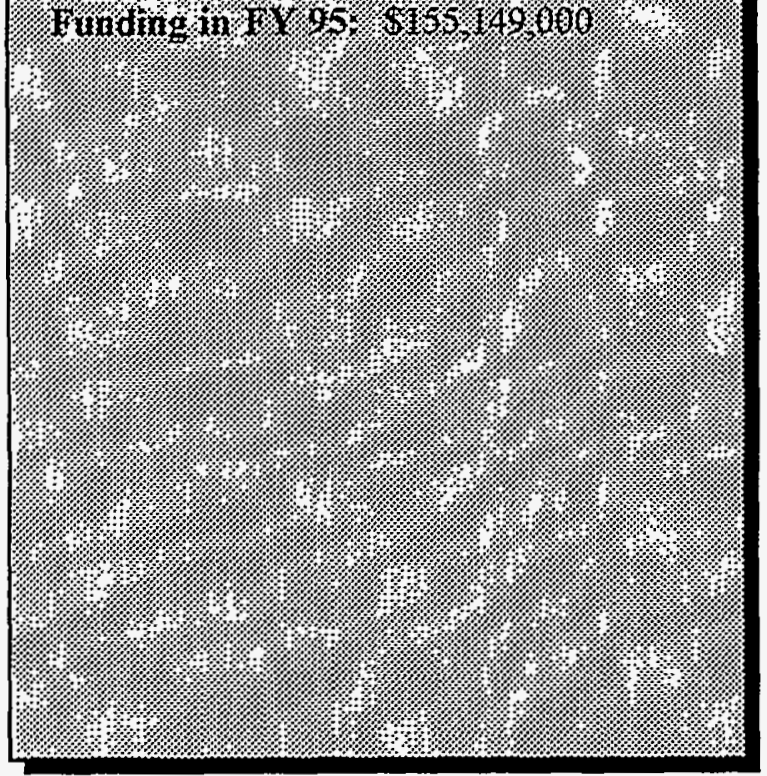

\section{Progress in Reaching Interagency Agreement}

At the time when FEMP was placed on the NPL, the site was engaged in activities aimed at compliance with the terms of an existing Federal Facility Compliance Agreement signed on July 18, 1986 between DOE and EPA Region V. The CERCLA portion of the Federal Facility Compliance Agreement was replaced by the signing of a Consent Agreement (an IAG) with EPA on April 9, 1990, which became effective on June 29, 1990. The Consent Agreement provides for the execution of RIFSs for five OUs and the performance of removal and remedial actions at the facility. DOE and EPA signed an Amended Consent Agreement which was executed on September 20, 1991. The amended Consent Agreement revised the milestones for submittal of these RI/FS documents to EPA and expanded the scope of the RI/FS to the former production area. The Amended Consent Agreement was modified in April 1993 as a result of an informal settlement concerning OU 2 schedules.

\section{Specific Cost Estimates and Budgetary Proposals Involved in Each Interagency Agreement}

Funds budgeted for environmental restoration under the Amended Consent Agreement at the FEMP total $\$ 196$ million of appropriated funding for FY 96 and $\$ 177$ million for FY 97 according to the request in the President's Budget.

\section{Public Comments Regarding Interagency Agreements}

No new public comments regarding the Consent Agreement were received in FY 95. 
Progress in Conducting Remedial Investigations/Feasibility Studies

The RI/FS process at the FEMP was initiated in July 1986 under the provisions of a 1986 Federal Facility Compliance Agreement. The 1990 CERCLA 120 and 106 Consent Agreement amended the CERCLA portion of the 1986 agreement and restructured the ongoing investigations into five distinct OUs. The 1991 Amended Consent Agreement revised the milestones for submittal of RI/FS documentation to EPA for five OUs, whereby separate RU/FS reports and RODs would be issued for each of the OUs. Additionally, the amended IAG established milestone dates for the submittal of select documents addressing all five OUs and a final combined site-wide OU. Progress in completing the RI/FS for each of the five OUs as defined under the provisions of the Amended Consent Agreement (as modified in April 1993) is summarized below.

\section{Affecting All OUs}

The Amended Consent Agreement provided for the submittal of a risk assessment work plan to establish the specific approach, parameters, and models to be employed to conduct OU baseline and FS risk assessments. Approval of this work plan was received from EPA in May 1992. A site-wide characterization report, required by the agreement, providing a preliminary site-wide baseline assessment was transmitted to EPA in August 1992. A site-wide CERCLA quality assurance plan pertaining to all facility environmental sampling and analysis was approved by EPA in September 1992. This plan integrates DOE and EPA quality assurance policies and principles.

\section{OU 1: Waste Storage Area}

This OU comprises the existing six FEMP waste pits, the Clearwell, the Burnpit, berms, liners, and soil within the OU boundary. The initial Screening of Alternatives Report was approved by EPA in January 1991. The final RI Report was submitted to EPA in February 1994 and, following comment resolution and incorporation, was approved by EPA in August 1994. The OU 1 draft FS Report and PP were submitted to EPA in March 1994. The Final Draft FS Report and PP were approved by EPA in August 1994. The PP was released for review by the public in August 1994, and a Public Hearing on the PP was held in August 1994. The Draft ROD for OU 1 was submitted to EPA in November 1994, and the Final ROD was signed in March 1995. The OU 1 draft RDWP was submitted in April 1995 to EPA, and the final RDWP was approved in June 1995. The RDWP identified the dates for submittal of the Preliminary Design Package and the Pre-Final Design Package to EPA as October 24, 1995 and March 21, 1996, respectively. Both packages are expected to be submitted on schedule. A Fernald Environmental Restoration Management Corporation task team, which includes the DOE, Fernald Area Office, has initiated definition of the scope, schedule, cost, and pros and cons of privatization of activities associated with the remediation of the waste pits. A determination is expected to be made in the summer of 1996. Initial review has indicated that the privatization concept could be used site-wide on other projects.

\section{OU 2: Other Waste Units}

This OU comprises the FEMP solid waste landfill, lime sludge ponds, flyash piles, and south field area. Site investigation activities within this unit included the completion of geophysical surveys, collection of representative waste and leachate samples from each waste unit, and the completion of over 25 wells in the vicinity of the waste units.

In accordance with the April 1993 revisions to the Amended Consent Agreement, the OU 2 revised RI report was submitted to EPA and Ohio and approved in January 1994. A formal public comment 
period began on October 26 and ended on November 25, 1994. A request to extend the public comment period was received on November 2, 1994. The Ross Township Board of Trustees formally requested a 30-day extension to the public comment period in order to allow additional time for the public to review the Proposed Plan for Remedial Actions at Operable Unit 2. In January 1995, the OU 2 FS/PP was approved. The OU 2 Draft ROD was submitted to EPA in February 1995, and approval was received in June 1995. The OU 2 RDWP was submitted to EPA in August 1995 and is expected to be approved early in FY 96. Preparation of the remedial design work packages continues, with expected completion scheduled for May 1996. The OU 2 Remedial Action Work Plan (RAWP) is scheduled to be submitted in May 1996 to EPA. Remedial action activities are scheduled to begin in September 1996.

\section{OU 3: Production Area and Production-Associated Facilities}

This OU comprises the FEMP former Production Area and production-associated facilities and equipment (including all above- and below-grade improvements), including but not limited to all structures, equipment, utilities, drums, tanks, solid waste, waste products, thorium, effluent lines, K-65 transfer line, wastewater treatment facilities, fire training facilities, scrap metal piles, feed stock, and coal piles. The Interim ROD to decontaminate and dismantle the facilities in OU 3 was approved by EPA in July 1994. The Interim RD/RA Work Plan was submitted to EPA in March 1995 and approved in May 1995. A combined Draft RI/FS/PP for OU 3 was submitted to EPA in September 1995 and is expected to be resubmitted in final form in January 1996. The Final ROD is scheduled for submittal to EPA in July 1996. The Draft RD/RA Work Plan is scheduled to be submitted to EPA in January 1997.

OU 4: Silos $1,2,3$, and 4

This OU comprises the four waste storage silos located in the FEMP waste storage area. The Initial Screening of Alternatives Report was approved by EPA in October 1990. The final RI report was approved in November 1993. The OU 4 FS/PP was conditionally approved in Febraary 1994. The PP was released for review by the public in March 1994, and a Public Hearing on the PP was held in March 1994. After consideration of public input, the Final ROD was signed by EPA in December 1994. Upon finalization of the ROD, the Amended Consent Agreement requires completion of an RD Work Plan. The RD Work Plan defines the strategy and schedule for development of the remedial design. The final $\mathrm{RD}$ Work Plan was approved by EPA in June 1995. Consistent with the Final RD Work Plan for OU 4, a phased approach is being utilized to accomplish remedial action activities. An RA Work Plan is being developed to identify the implementation strategy and schedule for completion of all remedial activities as set forth in the ROD.

There are two phases associated with the OU 4 RA Work Plan. Phase I will focus on initial RA activities in support of the construction of the Fernald Residues Vitrification Plant (FRVP) as follows: Underground Utilities/Site Preparation; Silo Superstructure Construction; and New Radon Treatment System Construction. Phase II will be prepared and submitted separately following integration of sufficient test data from the OU 4 Vitrification Pilot Plant so as to adequately address the following technical work scope: FRVP Process Building Construction and FRVP Operation. The Phase I RA Work Plan was submitted to the EPA and is expected to be approved early in FY 96. Implementation of final RA activities is scheduled to begin in March 1996 with issuance of the contract for underground utilities and site preparation. 


\section{OU 5: Environmental Media}

This OU comprises groundwater, surface water, soil, sediments, and flora and fauna in the vicinity of the FEMP not included in the definition of OUs 1 through 4. The Initial Screening of Alternatives Report was submitted to EPA in November 1992 and was conditionally approved in January 1993. EPA comments were incorporated and the Initial Screening of Alternatives was resubmitted to EPA in March 1993. A treatability study work plan was approved by EPA in September 1992. The RI report was submitted to EPA in June 1994 and approved in February 1995. The draft FS/PP Report was submitted to EPA in November 1994 and approved in April 1995. The OU 5 draft ROD was submitted to EPA in August 1995 and is expected to be approved in January 1996. The OU 5 draft RDWP is scheduled to be submitted in March 1996. OU 5 remediation is scheduled to begin in March 1997.

\section{Site Remediation Acceleration}

In March 1995, the Fernald Area Office submitted a proposal to accelerate the cleanup of the Fernald site to complete actions within either 5, 7, or 10 years. As a result of the Internal Review Board meeting held in May 1995, additional funding was provided to the Fernald project in support of the 10-year plan. The 10-year plan (FY 96 through FY 2005) is an accelerated schedule based on consistent funding of $\$ 276$ million per year for 10 years and other key cost and technical assumptions prepared by Fernald Environmental Restoration Management Corporation.

DOE currently estimates that the Fernald site will be cleaned up by the year 2005 for $\$ 3.13$ billion, with the exception of groundwater, which will require an additional $\$ 0.49$ billion. Total prior year costs for the project through FY 95 are $\$ 1.7$ billion, bringing the estimated total cost to $\$ 5.32$ billion. The acceleration of the cleanup (10-year plan) has reduced the overall cost by approximately $\$ 2.6$ billion.

During FY 95, DOE provided continued focus on integrating and refining the OU remedial action schedules with legacy waste and nuclear materials disposition efforts and other site-related initiatives to produce a more optimal life-cycle schedule for completion of FEMP's activities. This continued focus on integrating project activities highlighted key project schedule constraints and critical path activities and has resulted in identification of opportunities to significantly reduce life-cycle costs.

The proposal to accelerate cleanup at the Fernald site has created significant interest by local stakeholders and members of the Ohio Congressional delegation.

\section{Progress in Conducting Remedial Actions}

Final RODs for OUs 1, 2, and 3, and an Interim ROD for OU 4 have been approved by the EPA, and approval of the Final ROD for OU 5 is expected in January 1996. Therefore, site activities at Fernald have moved from the assessment phase into the cleanup phase. Further, several removal actions are planned or are underway.

\section{$\underline{\text { Removal Actions }}$}

Thirty removal actions have been designated for the Fernald site, two of which have multiple phases resulting in 34 actions. These actions have been assigned to various site complexes. Twenty-five actions have been completed, one has been canceled, and the remaining eight are in process. There 
were three removal actions completed in FY 95, and the status of the remaining eight removal actions is summarized in Table IV-1.

\section{Enforcement Activities}

On December 16, 1992, EPA and the Ohio Environmental Protection Agency disapproved the draft RI Report for OU 2, pending the resolution of extensive comments. All parties agreed that additional field sampling was needed to adequately characterize OU 2 and to address the comments. The regulators held that while DOE had fulfilled the scope of the approved OU 2 Work Plan and had conducted additional sampling, the objectives of the plan had not been met. DOE proposed revised schedules to accommodate the necessary sampling. The regulators determined that "good cause" did not exist for an extension.

During informal dispute resolution, an agreement was reached in early April 1993 which included the following provisions: OU 2 schedules are revised to reflect additional field sampling; RODs for three other OUs are each accelerated by 1 month; DOE will spend $\$ 2$ million on a supplemental environmental project intended to further reduce uranium releases to the Great Miami River; EPA assessed a $\$ 50,000$ stipulated penalty payable by DOE under the terms of the Amended Consent Agreement; and if DOE misses the revised milestone for the OU 2 ROD, an additional $\$ 25,000$ stipulated penalty may be automatically assessed. 
Table IV-1. Status of FEMP Removal Actions

\begin{tabular}{|c|c|c|}
\hline $\begin{array}{c}\text { REMOVAL } \\
\text { NO. } \\
\end{array}$ & NAME & ACTIVITIES \\
\hline 3 & $\begin{array}{l}\text { South Groundwater } \\
\text { Contamination Plume }\end{array}$ & $\begin{array}{l}\text { The Removal Action is subdivided into five parts: 1) provision of an alternate water supply to an } \\
\text { affected industrial user, 2) installation of a pump and discharge system for South Plume groundwater, } \\
\text { 3) construction and operation of Interim Advanced Wastewater Treatment systems, 4) South Plume } \\
\text { groundwater monitoring and installation of homeowner treatment systems, and 5) groundwater } \\
\text { modeling and geotechnical investigations. Field activities for Parts } 1,2 \text {, and } 3 \text { were completed prior to } \\
\text { FY 93, and operation of each of the units continues. Part 4, which includes sampling of private } \\
\text { homeowner and existing RI/FS wells in the South Plume area, continues. In addition, as part of the } \\
\text { OU } 2 \text { dispute resolution with EPA, DOE agreed to install a South Plume Interim Treatment system for } \\
\text { partial treatment of South Plume discharge water to further reduce uranium discharge to the Great } \\
\text { Miami River. Installation was completed and operation commenced in March 1994. Part } 5 \text { field } \\
\text { activities were completed in February 1994. }\end{array}$ \\
\hline 4 & $\begin{array}{l}\text { Silos } 1 \text { and } 2 \\
\text { (Bentonite } \\
\text { Installation) }\end{array}$ & $\begin{array}{l}\text { This Removal Action required the installation of bentonite clay in Silos } 1 \text { and } 2 \text { to eliminate the threat } \\
\text { posed by a potential release of residue and the acute release of radon gas. Monitoring activities for this } \\
\text { Removal Action continue. }\end{array}$ \\
\hline 5 & K-65 Decant Sump & $\begin{array}{l}\text { The objective of this Removal Action requires the removal of sludge and liquid from the K-65 Decant } \\
\text { Sump Tank. The tank has been accumulating liquid since it was emptied in } 1991 \text {. Once the tank is } 80 \\
\text { percent full, repumping is required. Current activities include monitoring the liquid level and } \\
\text { performing maintenance as needed. }\end{array}$ \\
\hline 9 & $\begin{array}{l}\text { Removal of Waste } \\
\text { Inventories }\end{array}$ & $\begin{array}{l}\text { FEMP procedures for the Removal of Waste Inventories were submitted to EPA in August } 1991 . \\
\text { These procedures detail the methods used in packaging and shipment of low-level waste, including } \\
\text { thorium, from the FEMP. Updated procedures were approved by EPA in October 1992, and in } 1995 \\
\text { Removal Action No. } 9 \text { was amended to include mixed waste inventories. Removal Action No. } 9 \text { will } \\
\text { continue through issuance of the OU } 3 \text { ROD. There were } 593,000 \text { cubic feet of low-level waste } \\
\text { disposed of in FY 95, 43,460 gallons of mixed waste were shipped to the TSCA incinerator, and } 2,317 \\
\text { cubic feet of solid mixed waste were shipped to Envirocare. }\end{array}$ \\
\hline
\end{tabular}


Table IV-1. Status of FEMP Removal Actions (Continued)

\begin{tabular}{|c|l|l|}
\hline $\begin{array}{c}\text { REMOVAL } \\
\text { NO. }\end{array}$ & \multicolumn{1}{|c|}{ NAME } & \multicolumn{1}{|c|}{ ACTIVITIES } \\
\hline 10 & $\begin{array}{l}\text { Active Flyash Pile } \\
\text { Controls }\end{array}$ & $\begin{array}{l}\text { This Removal Action requires the active flyash pile to be placed under control by regrading, the } \\
\text { application of dust suppressants, and installation of wind barriers and fences. Phase I, which involved } \\
\text { the completion of interim surface stabilization, is complete. Phase II, which involves completing the } \\
\text { active flyash pile controls, is ongoing. }\end{array}$ \\
\hline 12 & Safe Shutdown & $\begin{array}{l}\text { Safe shutdown procedures were submitted to EPA on October 30, 1991. Updated procedures were } \\
\text { approved by EPA in October 1992. These procedures detail the methods to be used to place the former } \\
\text { production facilities at the FEMP into a safe and permanent shutdown configuration. Field work began } \\
\text { in May 1993 and continues for several of the buildings. }\end{array}$ \\
\hline 17 & $\begin{array}{l}\text { Improved Storage of } \\
\text { Soil and Debris }\end{array}$ & $\begin{array}{l}\text { The objective of this Removal Action is to improve the soil and debris storage locations at the site by } \\
\text { providing run-off controls and covered structures. The Removal Action work plan was approved by } \\
\text { EPA in October 1992. Field work is ongoing. }\end{array}$ \\
\hline 26 & Asbestos Removals & $\begin{array}{l}\text { The objective of this Removal Action is to mitigate the potential for fugitive releases of asbestos. A } \\
\text { compendium of procedures supporting this Removal Action was submitted to EPA in May 1992. } \\
\text { Activities include small- and large-scale in-situ repairs, encasement, encapsulation, and removals. Field } \\
\text { work is ongoing. }\end{array}$ \\
\hline \multirow{\omega}{*}{} &
\end{tabular}


This Page Intentionally Left Blank. 


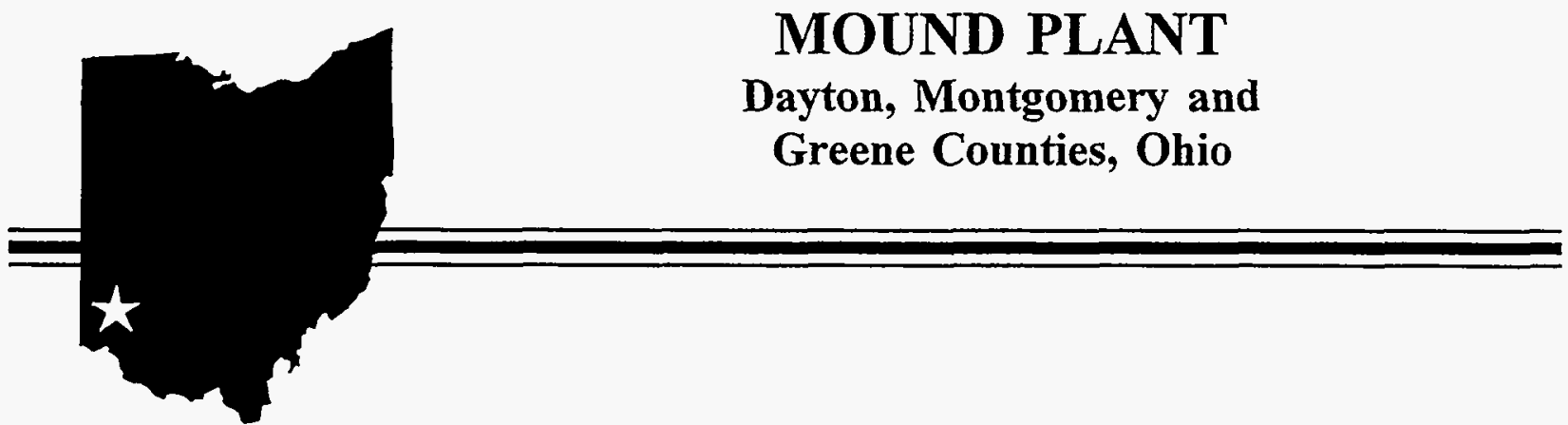

\section{Progress in Reaching Interagency Agreement}

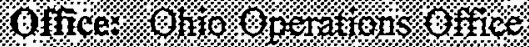

Size: 30.06 .

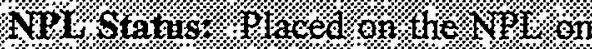

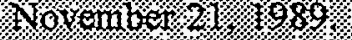

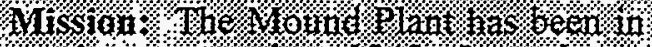

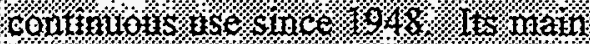

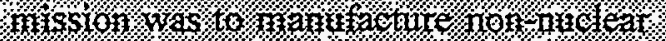

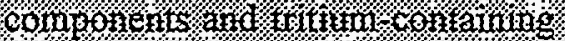

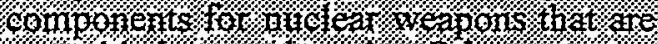

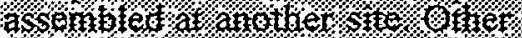

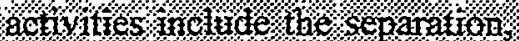

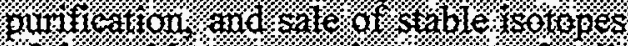
of the nobie gases. Soltit enengl: foss:

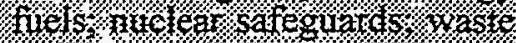

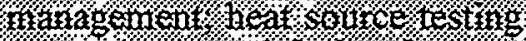

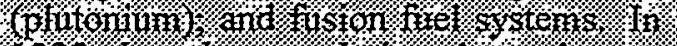

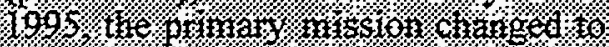

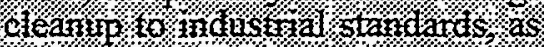

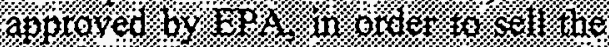

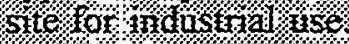

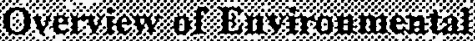

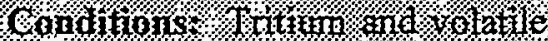

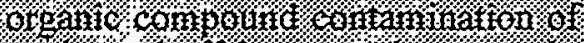

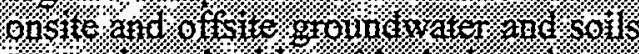

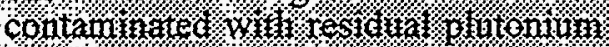

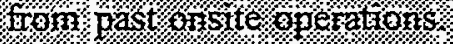

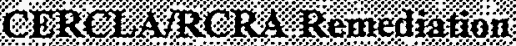

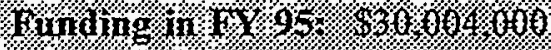

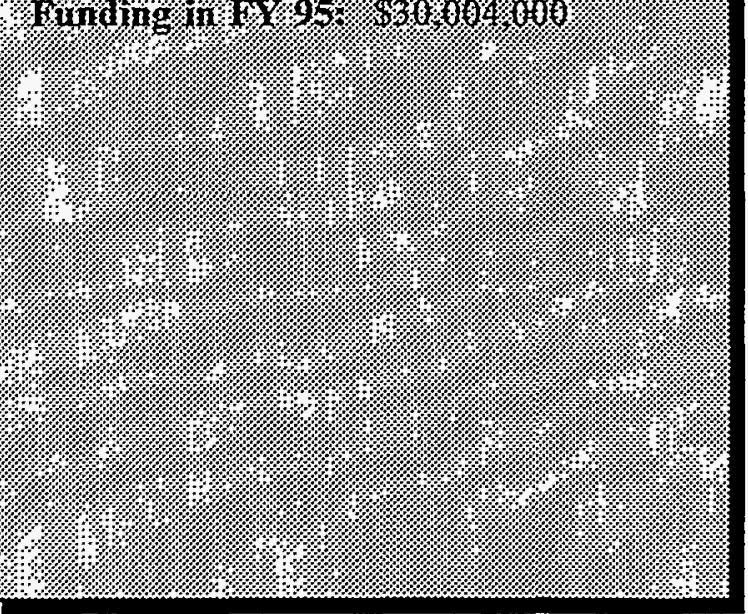

DOE and EPA Region V executed an FFA on August 6, 1990. The State of Ohio expressed an interest in developing a three-party agreement, with the State of Ohio being added to the FFA.

Negotiations were held on the development of the new three-party FFA, which were culminated by the signing of this new agreement on July 15, 1993.

\section{Specific Cost Estimates and Budgetary Proposals Involved in Each Interagency Agreement}

Funds budgeted for environmental restoration under the FFA total $\$ 42.7$ million of appropriated funding for FY 96 and $\$ 44.7$ million for FY 97 according to the request in the President's Budget.

\section{Public Comments Regarding Interagency \\ Agreements}

Prior to FY 93, limited public comments were received on the original 1990 FFA. Most of those comments inquired why the site was placed on the NPL. Limited comments were received during the FY 93 comment period for the new three-party FFA (no formal comment period in FY 94). EPA Region V, the State of Ohio, and DOE evaluated these comments and determined that no modifications to the FFA were required.

\section{Progress in Conducting Remedial Investigations/Feasibility Studies}

The Mound Plant originally was divided into nine OUs that separated the plant into discrete geographical units. OU 7 (Limited Action Sites) and OU 8 (Underground Tanks) had previously been closed out as needing no further action. OU 3 (Miscellaneous Sites) was closed out in 1993 as 
needing no further action. During FY 95, the ROD was completed for OU 1 (Area B/Groundwater). The design phase of the Miami-Erie canal removal action was initiated. The EPA approved the sale or lease of a 30-acre parcel of land.

Mound is currently re-baselining its cleanup effort to be more action oriented. Further assessment of the scope will be at the release site level. This re-baselining will result in an acceleration of cleanup at a reduced cost.

\section{Progress in Conducting Remedial Actions}

Implementation of three removal actions was completed in FY 95 for the B Building Solvent Storage Shed, the Firefighter Training Pit, and Area 7 tank removal. The B Building solvent shed has been dismantled, and a soil vapor extraction system was installed and operated to remove VOCs from the soil. The Area 7 tank removal was completed. Bioremediation was used to remediate dieselcontaminated soil from the firefighting training pit. Four subprojects of the special metallurgical building project were completed. They included structure removal, stack decontamination, breezeway removal, and catch basin remediation. 


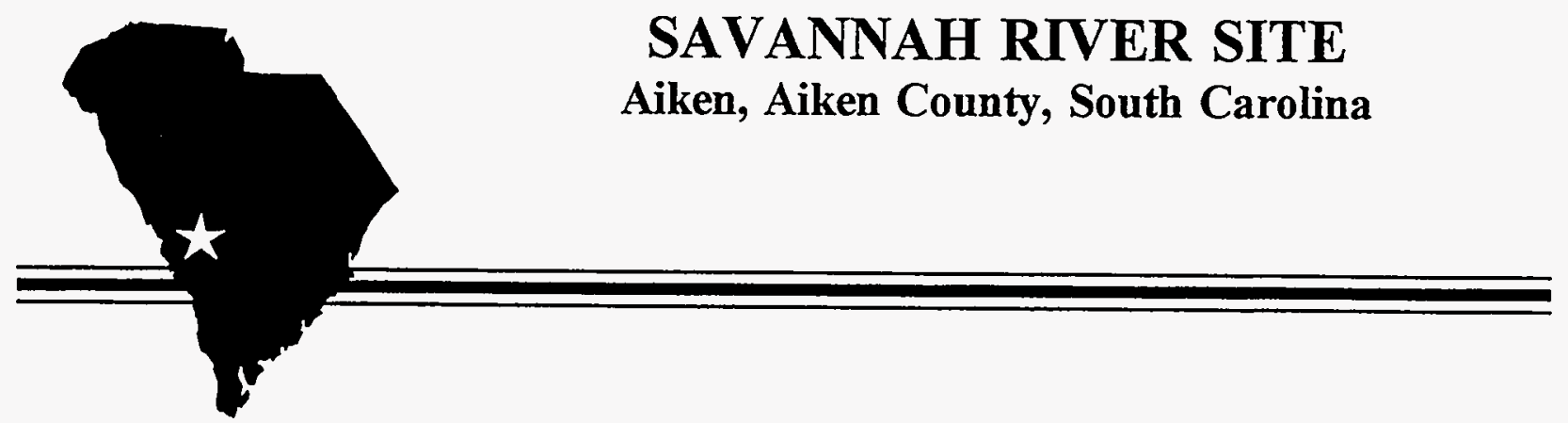

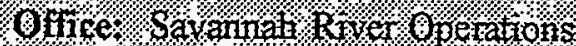
$0 \mathrm{frce}$

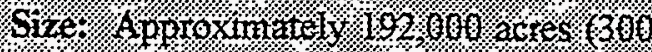
squatesulites)

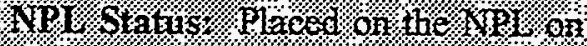
Torember 21.1989

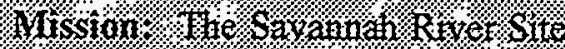

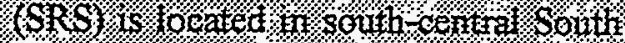

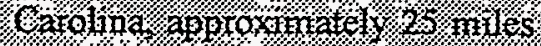

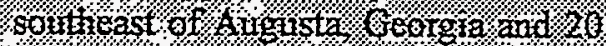

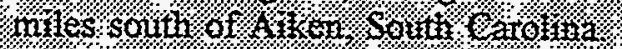

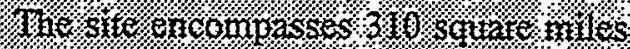

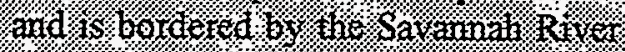

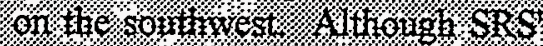

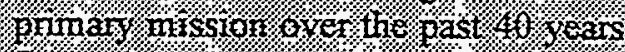

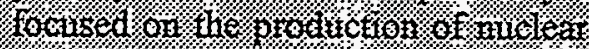

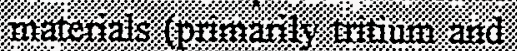

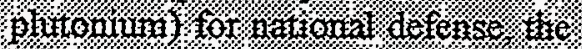

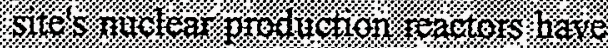

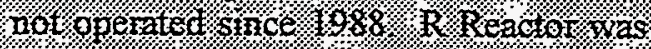

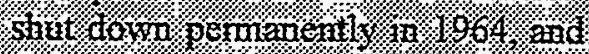

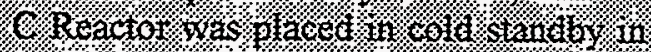

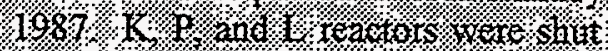

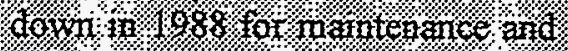

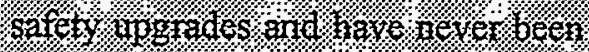

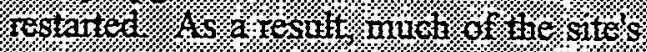

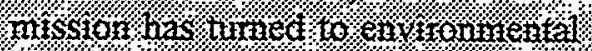

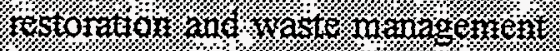

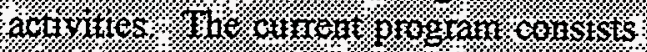

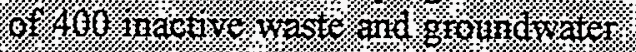

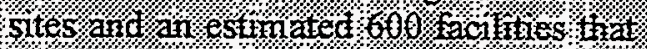

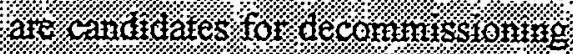
toontotiog

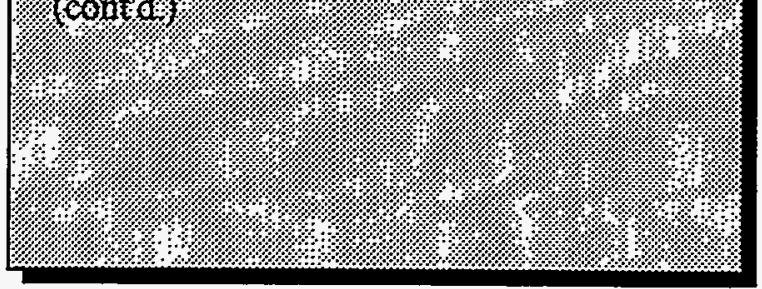

\section{Progress in Reaching Interagency Agreement}

DOE, EPA Region IV, and the State of South Carolina negotiated an IAG for SRS during calendar years 1990 through 1992. The IAG was executed on January 15,1993 and became effective on August 16, 1993.

\section{Specific Cost Estimates and Budgetary Proposals Involved in Each Interagency Agreement}

Funds budgeted for environmental restoration under the IAG total $\$ 76.7$ million of appropriated funding for FY 96 and $\$ 93.0$ million for FY 97 according to the request in the President's Budget.

\section{Public Comments Regarding Interagency Agreements}

The IAG Notice of Intent was signed on December 2,1991 . The document was released for 60-day public review on December 17, 1991; the public comment period ended on February 14,1992 . A public meeting was held on January 23, 1992.

Significant public comments focused on the specific roles and jurisdictions of the South Carolina Department of Health and Environmental Control (SCDHEC) and EPA Region IV in maintaining and enforcing DOE SRS cleanup actions.

The public comments also included concerns that the IAG should not limit SCDHEC's RCRA authority. The IAG was revised to better clarify dispute resolution procedures and authorities of the two regulators for oversight of RCRA and CERCLA cleanup activities.

Additionally, public comments showed the need to revise SRS' system of prioritizing waste units. The IAG was revised to include a priority system 


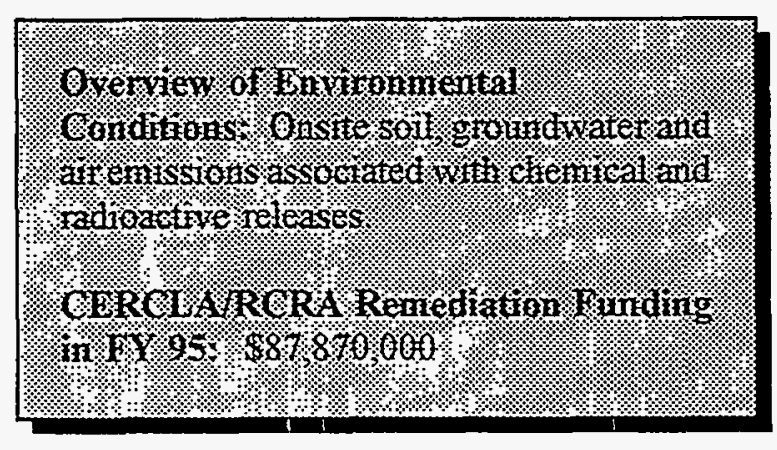

recommended by EPA, and a responsiveness summary addressing public comments was issued in 1993.

Comments requesting a site advisory board consisting of members of the public were addressed in a revised public involvement plan. SRS developed a site-specific advisory board, called the Citizens Advisory Board, which began functioning in 1994 and has made ten recommendations to DOE.

\section{Progress in Conducting Remedial Investigations/Feasibility Studies}

A RCRA 3004(u) permit was issued by EPA Region IV and the State of South Carolina on September 29, 1987. A program plan, which outlines the requirements for the preparation of unitspecific investigation plans and proposed plans, was revised on August 20, 1993. The following activities were accomplished during FY 95:

- Submitted 15 RFI/RI Plans; .

- $\quad$ Signed four remedial RODs;

- Submitted 13 RFI/RI and Baseline Risk Assessments;

- $\quad$ Conducted field characterization sampling and began data analysis at 38 waste sites;

- Completed site screening/evaluation at 24 additional sites and submitted 24 site Evaluation Reports;

- Continued implementation of the Field Investigation Plan at the Mixed Waste groundwater unit and Burial Ground Complex;

- Submitted two Corrective Measure Studies/FS Reports on CERCLA sites;

- Received approval on final RCRA closure plans for the Acid-Caustic Basins, Sanitary Landfill, and Low Level Radioactive Waste Disposal Facility;

- Submitted three RD/RA Work Plans; and

- Received approval on the F \& H Area Groundwater Operable Unit Proposed Plan from EPA and SCDHEC.

\section{Progress in Conducting Remedial Actions}

The following activities were accomplished in FY 95:

- Completed five remedial actions;

- Began operation of four vadose zone units to clean groundwater in A/M Area; 
- Began operation of A-2 air stripper to clean groundwater in A/M Area;

- $\quad$ Reached 2.25-billion-gallon mark in groundwater cleanup in $\mathrm{A} / \mathrm{M}$ Area, with more than 360,000 pounds of solvents removed;

- $\quad$ Completed Interim Actions at 15 additional waste sites;

- Completed Sanitary Landfill foundation layer construction to prepare for remediation;

- Completed Burial Ground Complex drainage system construction and completed sedimentation basins;

- Began operating an M-1 stripper air abatement system to treat organics from groundwater remediation system; and

- Began processing purge water using an onsite treatment system.

IV-45

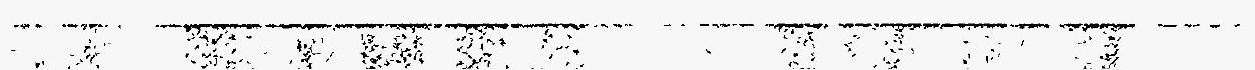


This Page Intentionally Left Blank. 


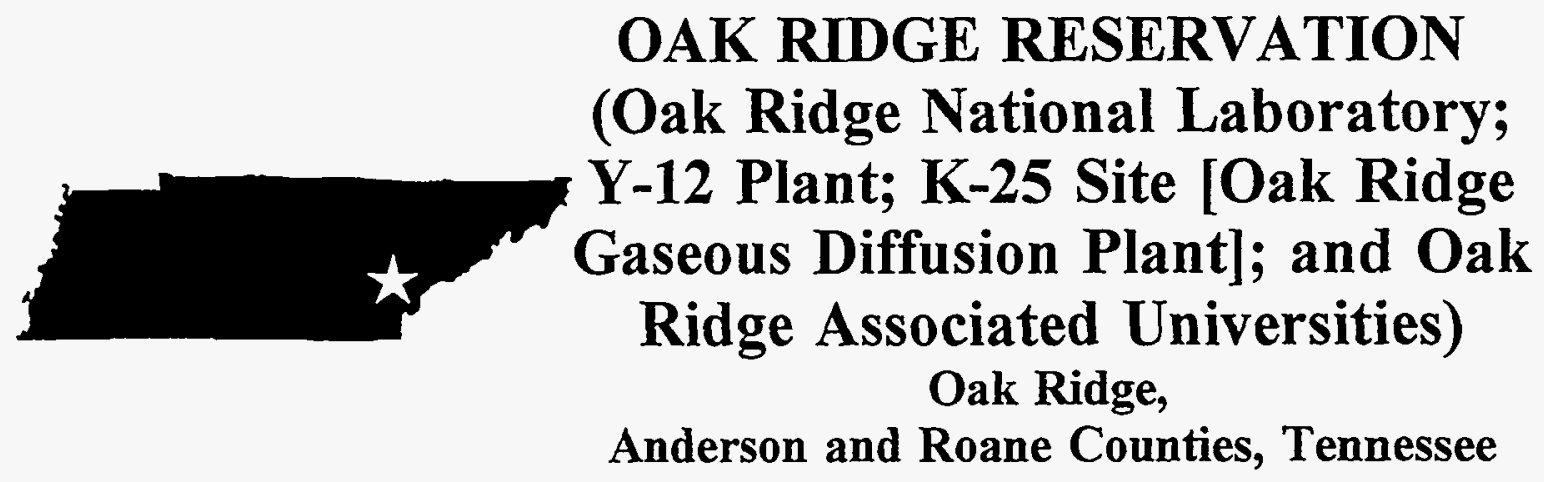

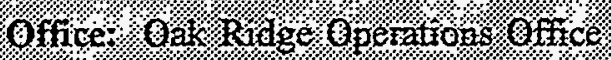

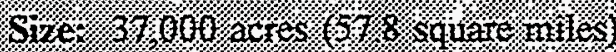

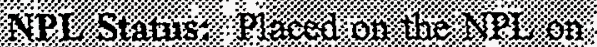
Voventber. 21.1698

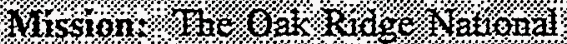

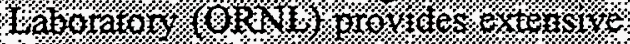

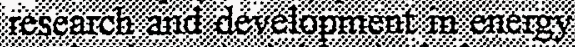

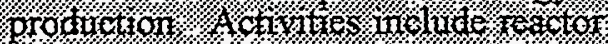

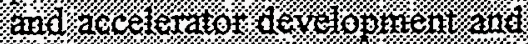

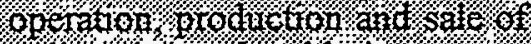

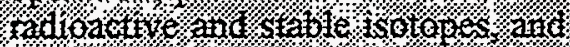

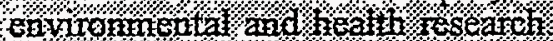

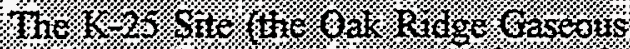

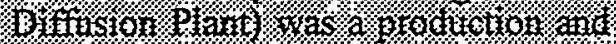

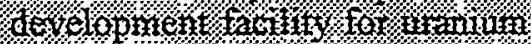

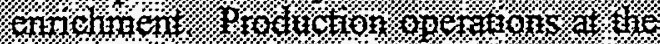

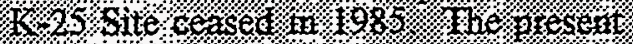

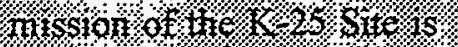

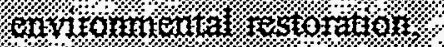

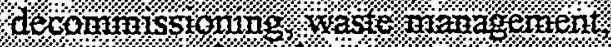

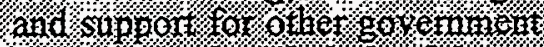

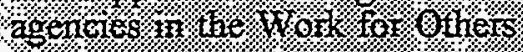
0108:

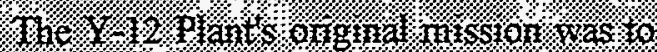

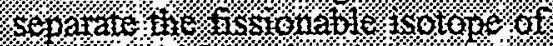

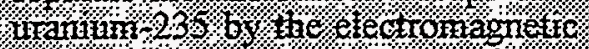

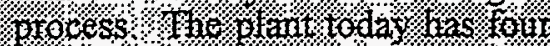

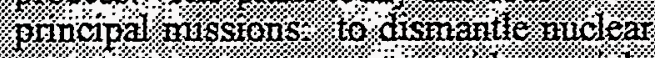

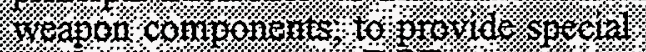

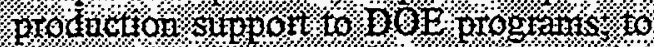

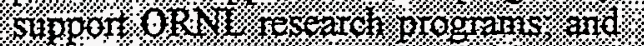

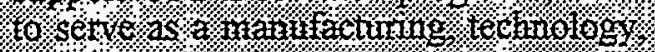

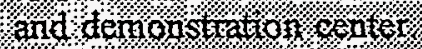

(0.010.6\%

\section{Progress in Reaching Interagency Agreement}

DOE, EPA Region IV, and the State of Tennessee have negotiated an IAG for the following sites included within the Oak Ridge Reservation (ORR): ORNL, Y-12 Plant, K-25 Site, ORAU, and the Clinch River. The IAG was effective on January 1 , 1992. In accordance with the IAG, the ORR is currently integrating the requirements of corrective measures under RCRA and applicable state law with response actions under CERCLA.

Specific Cost Estimates and Budgetary Proposals Involved in Each Interagency Agreement

Funds budgeted for environmental restoration under the IAG at the ORR total $\$ 89.5$ million of appropriated funds for FY 96 and $\$ 91.0$ million for FY 97 according to the request in the President's Budget.

\section{Public Comments Regarding Interagency} Agreements

The public comment period for the IAG closed on February 25, 1991. No comments were received. No new public comments regarding the IAG were received in FY 95.

\section{Progress in Conducting Remedial} Investigations/Feasibility Studies

To address contamination of the ORR as a whole, the reservation has been partitioned into 80 OUs/Work Units consisting of source control OUs and integrator OUs (such as groundwater and 


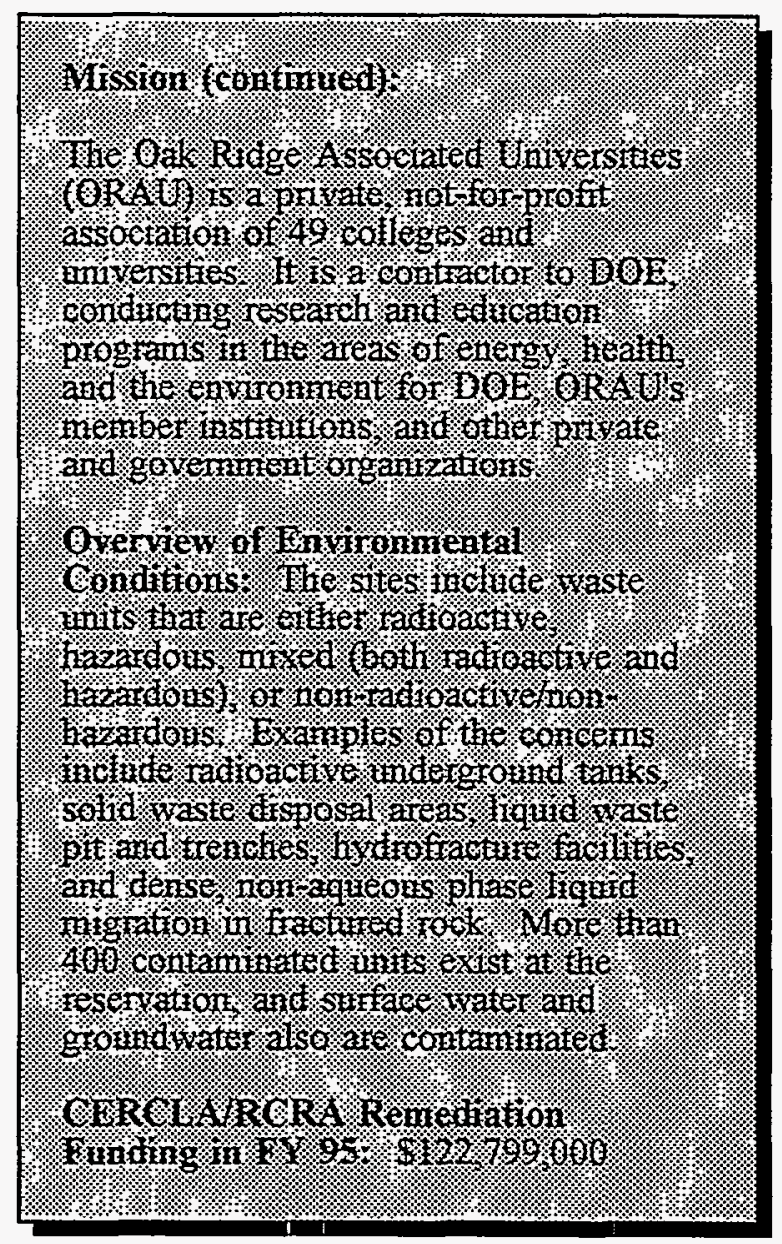

surface water), which can be prioritized to achieve the most effective and rapid investigation and cleanup possible. OUs are redefined and work schedules are adjusted as investigations progress and new data become available. RI/FSs are being conducted for each OU. Removal actions and interim remedial actions are conducted, where appropriate, to address threats to human health and the environment in advance of the final remedial action selection.

The remedial action work plans, site characterization studies, RI reports, and remedial design work plans have been prepared, using EPA guidelines for CERCLA RI/FSs and RCRA RFIs where appropriate. These documents were sent out in accordance with milestones specified in the negotiated IAG and the schedule defined in the RCRA permit. Public meetings were held during the year to advise the public of the restoration process being implemented to remediate the ORR and to address the public's concerns over the relative risk associated with the offsite contamination. Work completed or underway during FY 95 includes:

ORAU - The South Campus Facility RI/FS was submitted in February 1995 and approved in May 1995. Additionally, a PP was submitted for the South Campus Facility and approved in February 1995.

- ORNL - Completion of the WAG 5 RI and the WAG 1 Surface Impoundments RI/FS.

- Y-12 Plant - Completion of the Chestnut Ridge OU 2 PP and the Bear Creek Valley OU 2 PP.

- ORR (Offsite) - Completion of the Lower Watts Bar OU PP and ROD, and the Lower East Fork Poplar Creek OU PP and ROD.

\section{Progress in Conducting Remedial Actions}

Final CERCLA remedial action will be initiated after RODs are signed. Removal and interim cleanup actions completed or underway during FY 95 include:

- K-25 Site - Completion of the closures for the Pond Waste Management/Drum Repackage, the Main Plant Area/K-1407-B Holding Pond, and the Main Plant Area/K-1407-C Retention Basin. RCRA Closure Plans for the Main Plant Area/K-1417 Concrete Block Casting/Storage Area and the Main Plant Area/K-1419 Sludge Fixation Plant have been submitted. Submitted the Site Development Plan for the K-25 Site. Completed decommissioning for the six cooling towers wooden superstructures and the two K-25 Site Powerhouse Buildings. Completed the 
abatement of Risk Assessment Codes 1, 2, and 3 findings and partial reroof for K-1401 (Sections A and B).

- ORNL - Completion of the Core Hole 8 interim action, Molten Salt Reactor Experiment Auxiliary Charcoal Bed Cell isolation, and Molten Salt Reactor Experiment Purge and Trap System. WAG 6 Tumulus Pad Closure, WAG 6 Monitoring Station construction, WAG 5 Seeps C and D removal, assessments for the WAG 4 seeps, and the WAG 1 Gunite and Associated Tanks Treatability Study are in progress.

- Y-12 Plant - Completion of the Steamline Asbestos Removal, the Electrochemical Machinery Basement Area interim action, Y-12 Upper East Fork Poplar Creek Interim Drum Yard, and Building 9409-5 Tank Storage Area closures. Two assessments, WAG 4 seeps and WAG I, are in progress.

- ORR (Offsite) - The Lower East Fork Poplar Creek OU has proceeded to the construction phase of its remedial actions.

In addition, the ORR accomplished numerous community relations efforts with the regulators and the community during 1995. A few of these include:

- $\quad$ Agreements with the regulators on land use assumptions;

- Establishment of onsite disposal cells for Oak Ridge low-level and mixed waste by the year 2000;

- Establishment of higher mercury cleanup levels at Lower East Fork Poplar Creek from 50 ppm to $400 \mathrm{ppm}$, saving millions of dollars;

- Participation in the Data Quality Objectives process and the SAFER Pilot;

- Quarterly public information meetings and numerous project-level workshops; and

- Initiation of Oak Ridge and Paducah Site-Specific Advisory Boards. 
This Page Intentionally Left Blank 


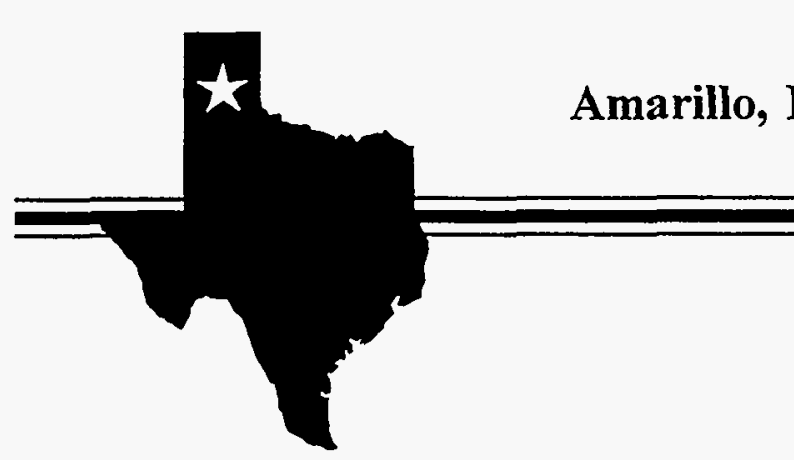
Amarillo, Potter and Randall Counties, Texas

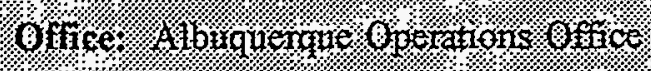

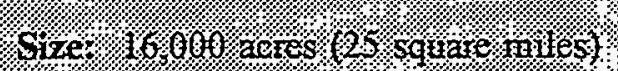

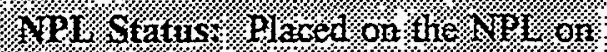

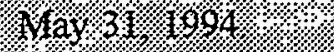

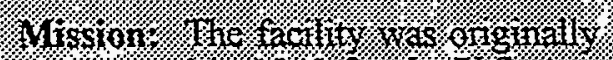

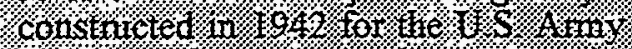

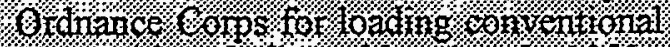

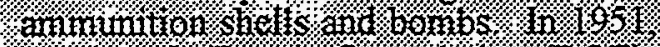

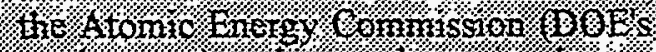

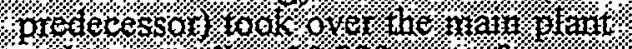

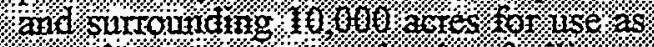

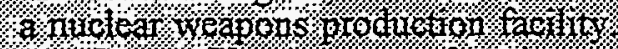

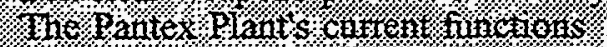

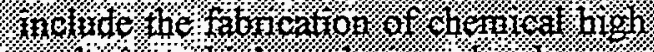

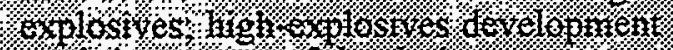
100th ins support of the ciesign

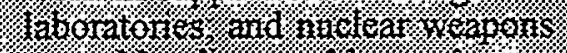

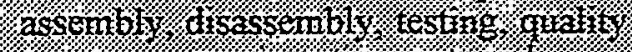

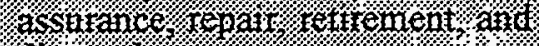
disposal

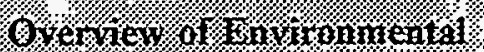

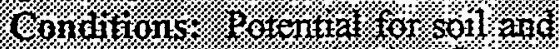

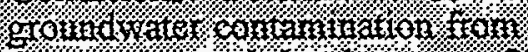

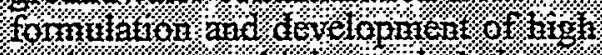

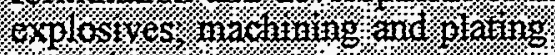
operafions, veapon conoportent tests.

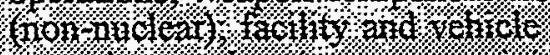

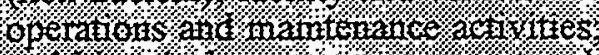

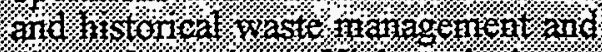

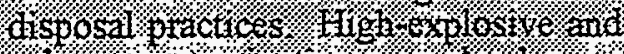

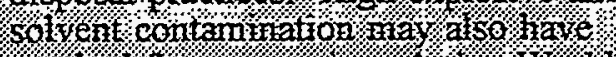

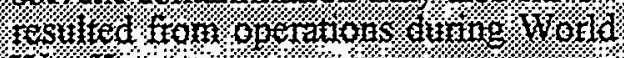
Wa. 11

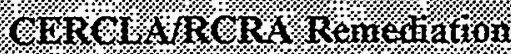

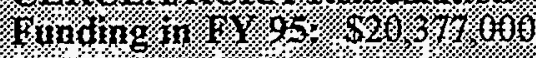

\section{Progress in Reaching Interagency Agreement}

Remediation of environmental conditions is currently being addressed under authority of a RCRA Part B Permit, issued June 6, 1991 by the Texas Natural Resources Conservation Commission (formerly the Texas Water Commission). FFA negotiations have been initiated with May 1996 targeted as the completion date.

\section{Specific Cost Estimates and Budgetary Proposals Involved in Each Interagency Agreement}

Funds budgeted for environmental restoration at the Pantex Plant total $\$ 12.8$ million of appropriated funding for FY 96 and $\$ 9.1$ million for FY 97 according to the request in the President's Budget.

\section{Public Comments Regarding Interagency Agreements}

No formal public comment occurred in FY 95 conceming the IAG. Pantex Plant has continued its aggressive community relations program during FY 95 by hosting an environmental science fair, holding monthly public information meetings, and participating in the monthly Pantex Plant Citizens Advisory Board. Supporting efforts include issuance of press releases for major milestones, dissemination of fact sheets and brochures, and maintenance of public reading rooms.

\section{Progress in Conducting Remedial Investigations/Feasibility Studies}

The assessment phase for eight projects was completed in FY 95. Four assessments will be completed in FY 96. 


\section{Progress in Conducting Remedial Actions}

A groundwater treatment system was designed, manufactured, and installed for use on the Zone 12 perched groundwater. This system was completed one year ahead of schedule at a saving of $\$ 1.5$ million. Removal actions were completed at the Fire Training Area burn pits and at four of the High Priority Release Sites. In FY 95, 61 solid waste management units were closed as No Further Action Required. In FY 96, 34 solid waste management units will be closed, and 11 interim corrective measures will be completed. 


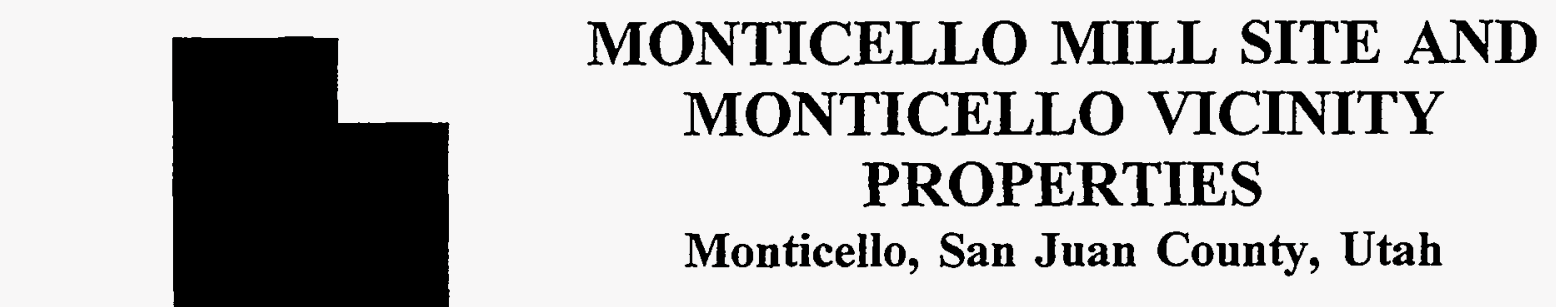

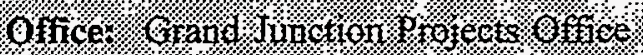

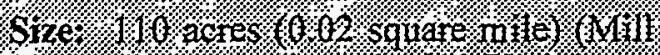

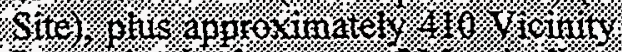

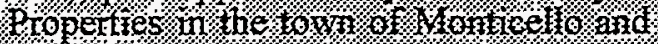

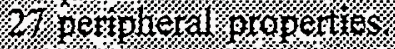

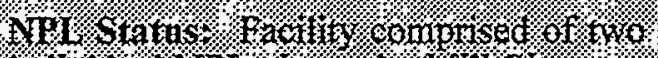

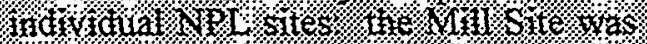

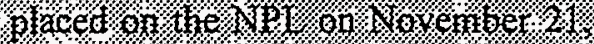

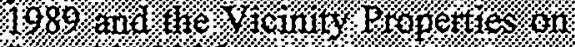

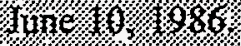

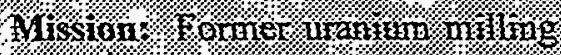
operatton.

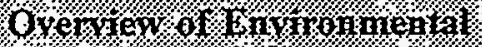

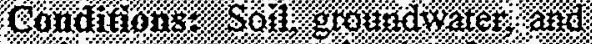

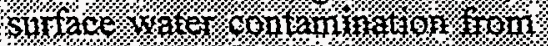

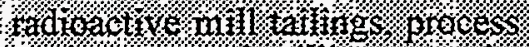

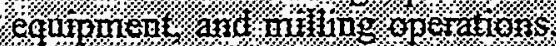

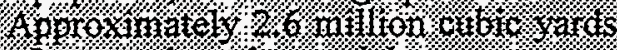
of contanininated donaterial?

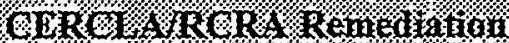

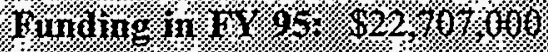

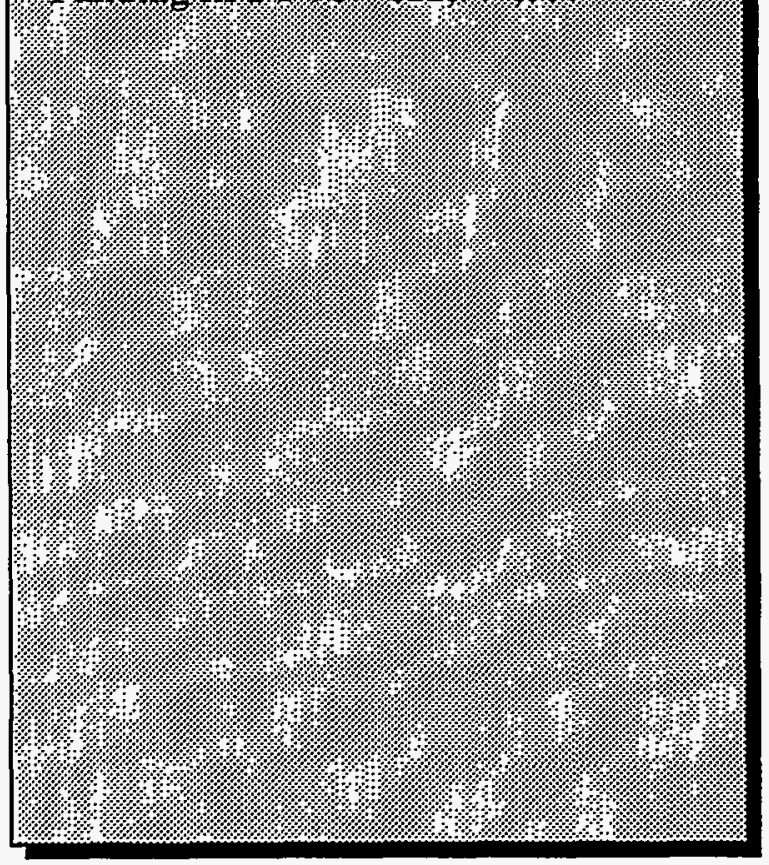

\section{Progress in Reaching Interagency Agreement}

DOE, EPA Region VIII, and the State of Utah negotiated and signed an FFA for the Monticello Mill Site and the Vicinity Properties. This FFA, which covered both NPL sites, was executed on December 22, 1988. The March 1995 Site Management Plan establishes the overall plan for remedial actions at Monticello. Enforceable milestones are established for the submission of primary documents as defined by the FFA.

\section{Specific Cost Estimates and Budgetary Proposals Involved in the Federal Facility Agreement}

Funds budgeted for environmental restoration under the FFA at the Monticello Mill Site and Vicinity Properties total $\$ 32.6$ million of appropriated funding for FY 96 and $\$ 32.6$ million for FY 97 according to the request in the President's Budget.

\section{Public Comments Regarding Federal Facility Agreement}

No new public comments regarding the FFA were received in FY 95.

\section{Progress in Conducting Remedial Investigations/Feasibility Studies}

Mill Site: The RI/FS addressing mill tailings and 22 peripheral properties was completed in 1990. An additional RU/FS addressing groundwater and surface water contamination and contamination of five peripheral properties commenced in 1992. A Phase I RI/FS Work Plan was approved by EPA and the State of Utah, and field activities were initiated. The baseline surface water and 
groundwater sampling for the Mill Site (OU 3) RI was completed and a Baseline Data Summary Report prepared. The Draft Final OU 3 RI/FS Work Plan, Field Sampling Plan, and Quality Assurance Project Plan were submitted for regulatory review in September 1995. Soil, sediment, surface water, groundwater, and biota sampling in support of the RI was completed in summer/fall 1995. Additional site characterization activities to support alternatives analysis and remedial design may be conducted in spring 1996.

Vicinity

Properties: The RU/FS for the Vicinity Properties was completed in calendar year 1989.

\section{Progress in Conducting Remedial Actions}

Mill Site: The ROD for OUs 1 and 2 of the Mill Site was signed by EPA in August 1990 and by DOE in September 1990; construction of site preparation facilities at OU 1 has commenced. These facilities include the installation of surface water drainage control structures, including the runoff retention pond for the 78-acre site and contiguous peripheral properties. Off-site drainage control ditches and the liner for Pond 3 were completed. To meet Utah discharge standards, the wastewater treatment plant was installed, tested, and operated to treat contaminated runoff. The Millsite Remediation design, which includes the on-site repository, was completed, and the subcontract for Millsite Remediation was awarded. Unnecessary groundwater monitoring wells were abandoned at the repository site. During FY 95 at OU 2, remedial action was started at three peripheral properties and was completed at one property. In addition, there were six project starts and six project completions in FY 95.

Vicinity

Properties: The ROD covering the Vicinity Properties was signed by EPA in September 1989 and by DOE in December 1989; since the last Annual Report to Congress, remedial actions have been completed on 375 of the project total of 411 . Eighty-one Vicinity Properties were remediated in FY 95. 


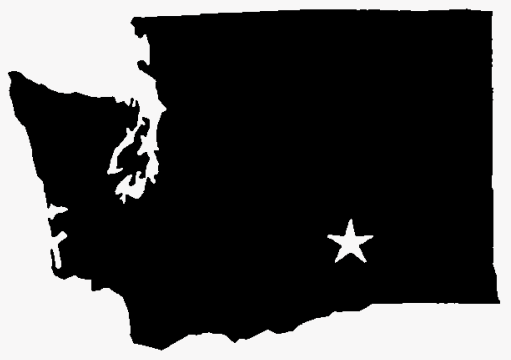

\section{HANFORD SITE \\ Richland, Benton County, Washington}

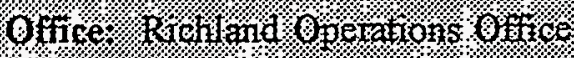

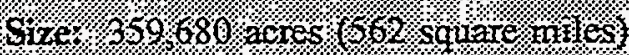

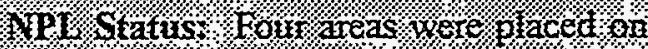

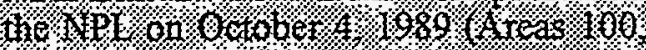

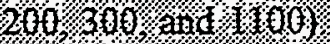

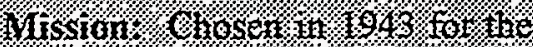

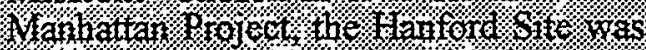

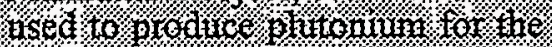

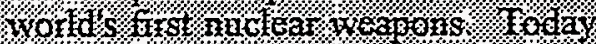

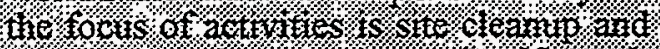

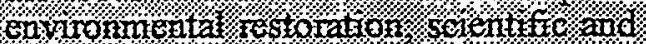

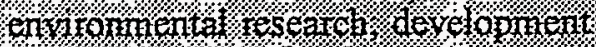

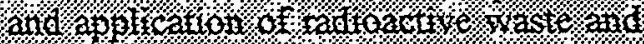

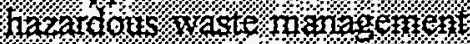

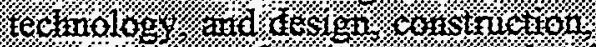

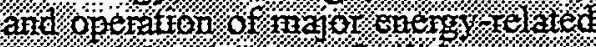

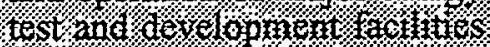

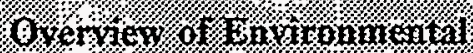

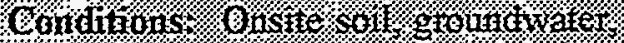

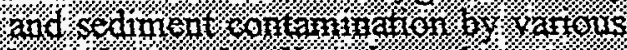

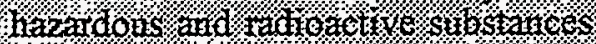

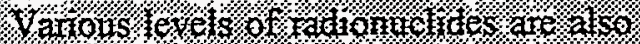

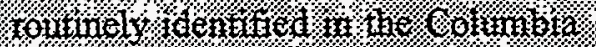
$\mathrm{Ri}$ inc.

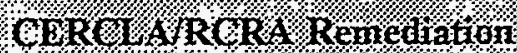

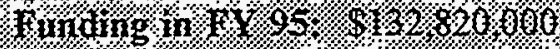

\section{Progress in Reaching Interagency Agreement}

DOE, EPA Region X, and the State of Washington negotiated and signed the Hanford Federal Facility Agreement/Consent Order (hereafter referred to as the Tri-Party Agreement) on May 15, 1989. This Tri-Party Agreement provides the framework for effective investigation of waste sites and subsequent remediation of hazardous and mixed waste contamination at Hanford. An annual update is prepared to address additional problems and to incorporate schedules agreed to in approved RI/FS Work Plans or other work scopes agreed to by the three parties. Revision 2 of the Tri-Party Agreement was published in September 1992, which included the second and third amendments to the Consent Order.

On May 23, 1993 negotiations began on significant changes to the Tri-Party Agreement. Change for CERCLA activities included development and inclusion of milestones related to the proposed Environmental Restoration Disposal Facility, consolidation of the 300 Area OUs into a single CERCLA project, and accelerated groundwater remediation projects. The Environmental Restoration Disposal Facility incorporated NEPA values into the CERCLA process as a result of the Environmental Restoration Disposal Facility exemption from NEPA in the 1993 Tri-Party Agreement negotiations. Moreover, under CERCLA, the Environmental Restoration Disposal Facility is exempted from having to obtain permits. The amended Tri-Party Agreement was signed on January 25, 1994.

In July 1994, the DOE, EPA Region X, and the Washington State Department of Ecology agreed to negotiate on matters related to Hanford's

"Refocusing Environmental Restoration" program. 
The parties agreed to negotiate cleanup schedules in order to achieve earlier remediation of sites along the Columbia River, and to increase emphasis on protecting and remediating groundwater. In addition, the parties agreed to consult with affected Indian Nations and other stakeholders to seek and respond to their values and concerns. The parties concluded formal negotiations on September 30, 1994, and the amended Tri-Party Agreement was signed on July 28, 1995 after a 45-day public comment period.

Negotiations on Amendment 6 are expected to be completed in October 1995, and the public comment period is expected to end in December 1995. This amendment primarily addresses ways of becoming more efficient and cost-effective within the framework of the Tri-Party Agreement. The proposed changes fall into these broad categories:

1) Single Regulator Approach (eliminating support agency staffing);

2) Eliminating current Tri-Party Agreement Project Manager positions and providing unit managers and their line managers with increased responsibility and authority regarding their projects; and

3) Streamlining the dispute resolution/decision-making process.

For detailed information regarding the Tri-Party Agreement, see the FY 91 CERCLA 120 Report to Congress.

\section{Specific Cost Estimates and Budgetary Proposals Involved in Each Interagency Agreement}

Funds budgeted for CERCLA activities in the environmental restoration program under the Tri-Party Agreement total $\$ 110$ of appropriated funding for FY 96 and $\$ 90.9$ for FY 97 according to the request in the President's Budget.

\section{Public Comments Regarding Interagency Agreements}

Amendments and updates to the Tri-Party Agreement are subject to public comment periods prior to signature by the three parties. The most recent Tri-Party Agreement renegotiation package underwent 45 days of public comment during 1995. The amendment was signed by the three parties on July 28, 1995. For detailed information regarding the Tri-Party Agreement comment process, see the FY 91 CERCLA 120 Report to Congress. All future changes to the Tri-Party Agreement will also be subject to public review and comment.

\section{Progress in Conducting the Remedial Investigations/Feasibility Studies}

The Hanford Site includes a broad range of waste units that contain either radioactive, hazardous, mixed (both radioactive and hazardous), or nonradioactive/nonhazardous solid waste. Certain hazardous substances and hazardous wastes remain on and under the Hanford Site and have been detected in groundwater and surface water. An estimated 5 billion cubic yards of solid and dilute liquid waste, including hazardous substances, mixed waste, and hazardous waste and constituents, have been disposed of at the Hanford Site.

All remediation work at the Hanford Site is included within four NPL sites (the 100,200,300, and 1100 Areas), 74 source OUs containing 1,249 identified hazardous waste sites (985 past-practice sites), and 4 groundwater OUs. OUs were prioritized by EPA and the State of Washington in 1989 for investigation based on an initial assessment of environmental risk. 
The following activities were accomplished during FY 95:

100 Area

- Eight CERCLA PPs were submitted to the regulators for the 100-BC-1, 100-BC-2, 100-BC-5, 100-DR-2, 100-FR-1, 100-KR-1, 100-KR-4, and 100-HR-2 OUs;

- The burial ground excavation treatability test at 118-B-1 was completed;

- A CERCLA ROD was issued for the 100-BC-1, 100-DR-1, and 100-HR-1 OUs; and

- Nine Focused FS Reports were submitted to the regulators for the $100-\mathrm{BC}-1,100-\mathrm{BC}-2$, 100-BC-5, 100-DR-2, 100-FR-1, 100-KR-1, 100-KR-4, and 100-HR-2 OUs.

$\underline{200 \text { Area }}$

- One CERCLA PP was submitted for the 200-UP-1 OU;

- The 200-BP-5, 200-ZP-1, and 200-UP-1 pump and treat treatability tests were completed. Pump and treat will continue at 200-ZP-1 and 200-UP-1 as part of the remediation. It was determined that extraction rates were insufficient to be effective at 200-BP-5, and this pump and treat operation was terminated;

- The Environmental Restoration Disposal Facility CERCLA ROD was issued and construction started;

- A CERCLA ROD was issued for remediation at the 200-ZP-1 OU to address groundwater contamination;

- A Focused FS Report for the construction of Engineered Barriers to isolate underground waste was submitted; and

- A Limited Field Investigation Report for the 200-UP-2 OU was submitted.

$\underline{300 \text { Area }}$

- $\quad$ A Phase 3 FS Report was submitted for the 300-FF-5 OU;

- A Phase 2 RI Report was submitted for the 300-FF-5 OU; and

- $\quad$ A Limited Field Investigation Report was submitted for the 300-FF-2 OU.

$\underline{1100 \text { Area }}$

- Assessment activities in the 1100 Area were completed before FY 95 began.

Progress in Conducting Remedial Actions

Under the Hanford Site Past Practice Strategy, sites that pose a threat to human health and the environment are identified. These sites are considered for Expedited Response Actions (ERAs). 
The following ERA activities were accomplished in FY 95:

100 Area

- The N-Springs ERA is located near the N-Reactor. Past liquid effluent discharges have led to strontium-90 radionuclide releases along the southern bank of the Columbia River, known as $\mathrm{N}$-Springs. In August 1995 operations of a groundwater treatment system at N-Springs began. DOE plans to decide on the technical feasibility of installing an underground barrier wall in FY 96 to further inhibit contaminant movement.

\section{$\underline{200 \text { Area }}$}

The 200 West Area carbon tetrachloride treatment site (located in the 200-ZP-2 OU) vapor extraction continues. The system is now automated. Through September 1995, more than 140,000 pounds of carbon tetrachloride have been removed.

There were no ERAs done during FY 95 in either the 300 or 1100 Areas.

Other accomplishments include:

100 Area

- $6,800,000$ gallons of groundwater have been pumped and treated at the $100-\mathrm{HR}-3 \mathrm{OU}$.

\section{$\underline{200 \text { Area }}$}

- Pump and treat is continuing as remediation in the 200-ZP-1 and 200-UP-1 OUs; 4,200,000 gallons and 4,900,000 gallons respectively have been treated through FY 95 at these OUs.

$\underline{300 \text { Area }}$

The PP for the 300-FF-1 and 300-FF-5 OUs is currently out for public review. Remediation will begin after issuance of a PP and ROD.

\section{Area}

- Cleanup of the 1100 area was completed in FY 95. The 1100 area cleanup consisted of excavation of PCB-contaminated soil from the Horn Rapids Landfill and Ephemeral Pool and construction of a cap. In addition, smaller stained soil sites were cleaned up by excavating and disposing of the materials offsite. The 1100 Area is primarily used as a vehicle garage and maintenance area for the Hanford Site.

\section{Enforcement Activities}

In October 1990, DOE stopped construction of the low-level mixed waste laboratory (Milestone M-14-00) in order to review options for obtaining analytical services from commercial laboratories. DOE subsequently resumed construction of a smaller laboratory. In October 1991, DOE submitted a request to change Milestone M-14-00 from construction of a laboratory to assurance of adequate laboratory capacity for mixed waste samples under the IAG. This request was denied by EPA and the State of Washington in November 1991, and DOE initiated dispute resolution under the 
IAG. In April 1992, the Senior Executive Committee agreed on a proposal to resolve the issue. As a result of the delay in schedule, and based on public comment, the state required further changes to the agreement to mandate that analytical laboratory services be acquired in the vicinity of Hanford. In addition, the state required DOE to pay a $\$ 100,000$ penalty, to perform an ERA of the N-Springs, and to establish IAG milestones for completion. DOE is committed to complete existing (approved) ERAs and the $\mathrm{N}$-Springs response action.

DOE has completed an EE/CA for the $\mathrm{N}$-Springs ERA. DOE has also received an Action Memorandum from the Washington State Department of Ecology directing it to proceed with the selected alternative of barrier wall construction and emplacement of a groundwater pump and treat operation. During February 1995, initial tests to drive a barrier wall into the ground at the N-Springs were unsuccessful. DOE and the regulators plan to make a decision on the technical feasibility of the barrier wall in February 1996. 
This Page Intentionally Left Blank.

IV-60 


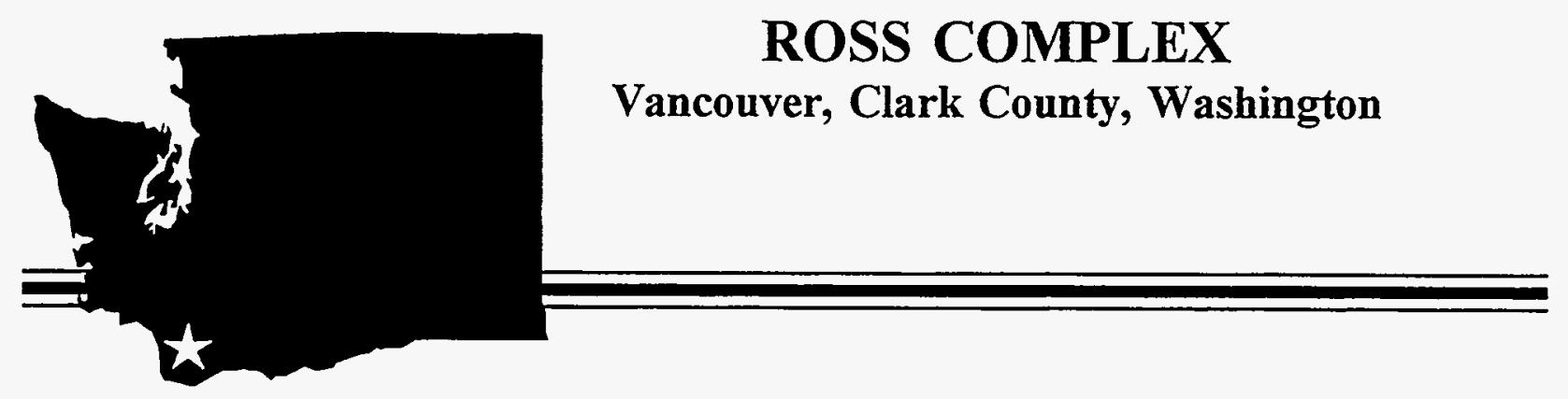

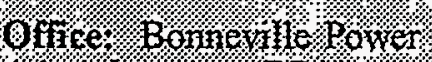
A.trintatistratton: $\mathrm{BP}$ -

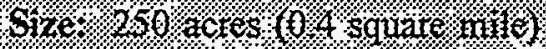

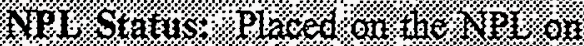

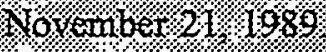

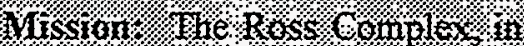

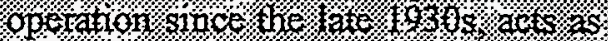

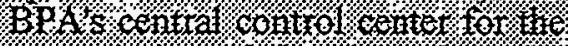

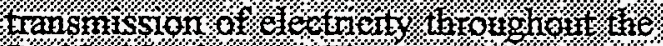

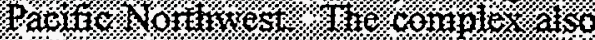

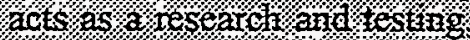

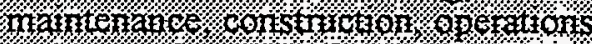

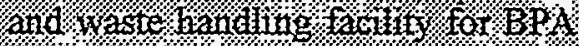

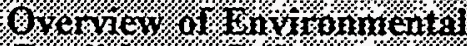

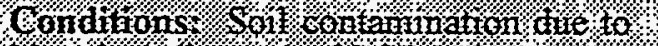

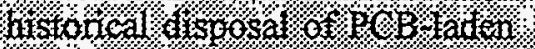

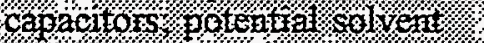

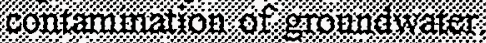

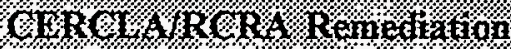

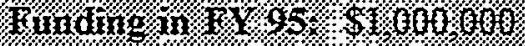

\section{Progress in Reaching Interagency Agreement}

DOE, EPA Region $X$, and the State of Washington executed an IAG for the Ross Complex site on May 1, 1990. The agreement serves as a framework for conducting remedial activities in accordance with CERCLA Section 120 and the NCP.

\section{Specific Cost Estimates and Budgetary Proposals Involved in Each Interagency Agreement}

Funds budgeted for environmental restoration under the IAG total \$0 million for FY 96 and \$0 million for FY 97.

\section{Public Comments Regarding Interagency Agreements}

No new public comments regarding the IAG were received in FY 95.

\section{Progress in Conducting Remedial Investigations/Feasibility Studies}

The RI/FS scope of work was completed and submitted to EPA Region X and the State of Washington on March 15, 1990. The RU/FS work plan was submitted to all parties on June 7, 1991. It was reviewed and approved by EPA and the state. Phase I of the RI field work was completed in September 1991. Field work for Phase II of the RI was completed in August 1992.

In an agreement with EPA and the state, the site was divided into two OUs. OU A addresses surface soil contamination, and OU B addresses belowsurface contamination, principally groundwater. 
No further actions were required in FY 95.

\section{Progress in Conducting Remedial Actions}

The RI report for OU A suggested that contaminant concentrations found in the soils at the Ross Substation, Capacitor Test Lab and Wood Pole Storage Area, East may pose an unacceptable risk of occupational exposure to carcinogens. Remediation of Ross Substation and the Capacitor Test Lab was accomplished by removing PCB-contaminated surface soil in January 1994. Onsite remediation of the Wood Pole Storage Area was initiated during the summer of 1994 and is expected to be completed in FY 96.

In addition, the results of the RI for OU A indicated that certain contaminant concentrations in seven individual waste units exceeded soil cleanup levels promulgated under the Washington State Model Toxics Control Act. BPA undertook independent actions at these seven locations consisting of excavation and disposal of surface soils. These removal action were begun on June 15, 1992 and were completed on July 6, 1992.

Based on the draft RI report for OU B, it has been demonstrated that the residual occurrence of limited volatile organics in the groundwater does not constitute an onsite or offsite risk to human health. Continued groundwater monitoring is planned for the next few years. The last groundwater analysis conducted in August 1995 showed that for all monitoring wells tested, contaminants of concern were below maximum contaminant levels.

Cleanup of the Capacitor Test Lab, initiated in January 1994, is now complete. Installation of a multilayer cap over the Fog Chamber Dump was completed on October 19, 1994. Contaminated soil from the Wood Pole Storage Area was excavated in the summer of 1994 and treatment onsite utilizing enhanced bioremediation is expected to be completed in FY 96. Removal of PCB-contaminated soil from the Ross Substation was accomplished in January 1994. The cleanup or removal of the substation capacitor yard soil and the replacement of PCB equipment is expected to be completed early in FY 96. This PCB removal is the last of the remediation activities included in the RODs. 
SECTION V

SITE SUMMARIES FOR SELECTED FACILITIES NOT ON THE NPL (BY STATE) 


\section{SITE SUMMARIES FOR SELECTED FACILITIES NOT ON THE NPL (BY STATE)}

This section of the annual report to Congress provides descriptions of selected DOE facilities not on the NPL. The level of CERCLA funding allocated to these sites drives their selection for presentation in this section. This section is not required by CERCLA 120(e)(5); it is provided for public information. The information provided includes background summary information, environmental conditions, and funding information. Figure I-l presents the geographic location of the sites subject to Section 120 of CERCLA, including the sites highlighted in this section. 
This Page Intentionally Left Blank. 


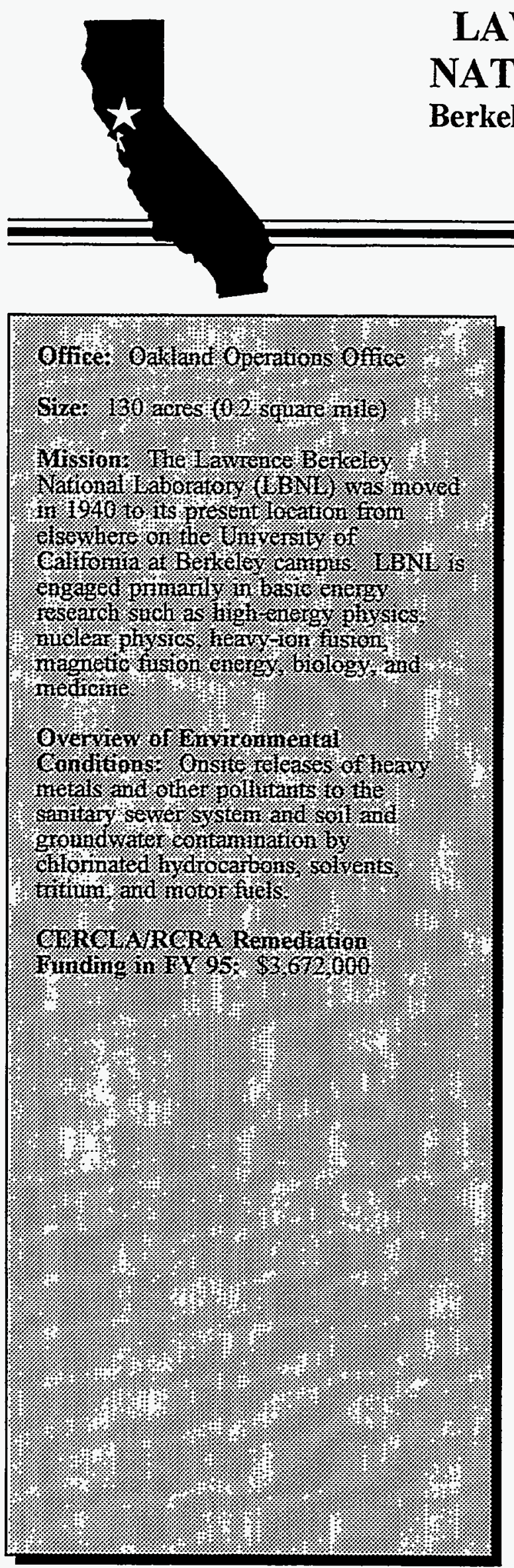

Remediation of environmental conditions at LBNL is being addressed under authority of a RCRA permit, which includes corrective action requirements. The site has been classified as Site Evaluation Accomplished.

\section{Specific Cost Estimates and Budgetary Proposals}

Funds budgeted for environmental restoration at LBNL total $\$ 4.2$ million of appropriated funding for FY 96 and $\$ 3.7$ million for FY 97 according to the request in the President's Budget.

\section{Progress in Conducting Remedial Actions}

LBNL corrective actions are being conducted in compliance with the site's RCRA Part B Permit. As part of this process, a RCRA Facility Assessment (RFA) was conducted by the State of Califomia and LBNL. Because of the Part B Permit and the RFA requirement, the State of California requested LBNL to submit an RFI Work Plan in accordance with the RCRA corrective action process. The RCRA investigation process follows a phased approach starting with the RFA, followed by an RFI and corrective measures study. LBNL completed its RFA in July 1992. RFI activity commenced in FY 92, and the RFI work plan was submitted to the State of California in November 1992. The first RFI progress report was sent to regulators in November 1994 and a second will be prepared by November 1995, with a final RFI report scheduled for delivery to regulators in February 1997.

The Old Town Plume Corrective Measures Work Plan is expected to be submitted in FY 96. 
This Page Intentionally Left Blank. 


\title{
SANDIA NATIONAL LABORATORIES/CALIFORNIA
}

\author{
Livermore, Alameda County, California
}

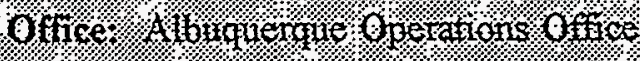

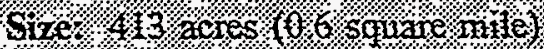

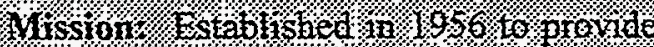

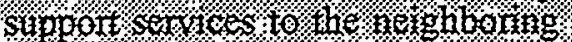

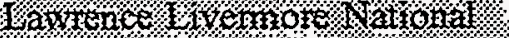

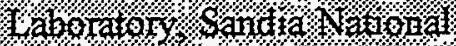

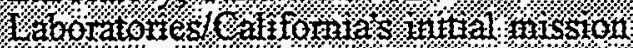

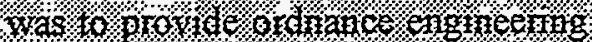

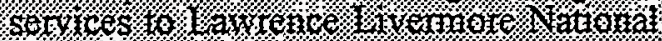

Tabonatong 1 current progtranst being

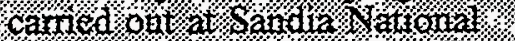

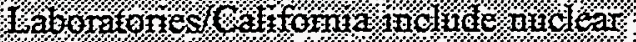

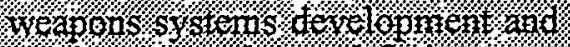

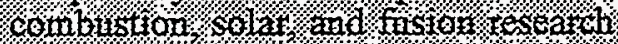

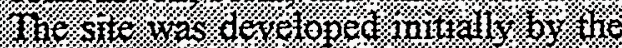

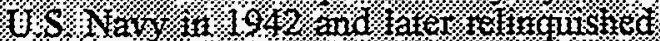

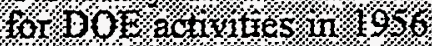

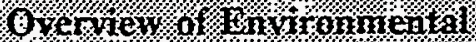

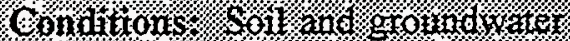

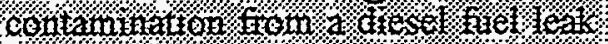

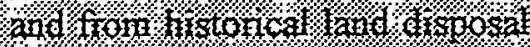

01actices

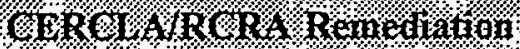

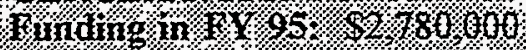

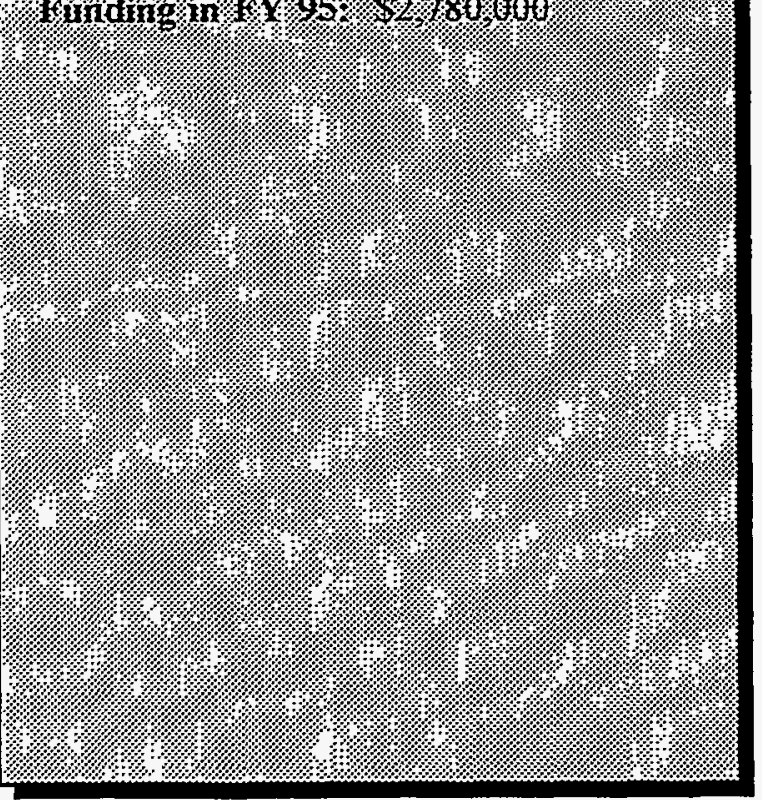

Remediation of environmental conditions at Sandia National Laboratories/California is being addressed under authority of a State of California Cleanup Order.

\section{Specific Cost Estimates and Budgetary Proposals}

Funds budgeted for environmental restoration at Sandia National Laboratories/California total $\$ 2.8$ million of appropriated funding for FY 96 and $\$ 2.6$ million for FY 97 according to the request in the President's Budget.

\section{Progress in Conducting Remedial Actions}

On October 15, 1987 a PA/SI was submitted to EPA in response to CERCLA Section 120 requirements. To date, EPA has not completed a Hazard Ranking System evaluation for this site.

In December 1989, the State of Califormia RWQCB issued a Site Cleanup Order (No. 89-184) to DOE and the Sandia Corporation. This order modified Order 88-142 requiring the consolidation of all site work to be accomplished by the Sandia Corporation and DOE, and set forth provisions and specifications for development and implementation of soil cleanup alternatives for identified areas of soil and groundwater pollution. Four areas of potential soil and groundwater pollution were identified in the Cleanup Order: Trudell Auto Repair Shop, Fuel Oil Spill, Navy Landfill, and Miscellaneous Sites. RIs at all four sites were completed in 1991.

Regarding the cleanup of the Fuel Oil Spill site, authorization to proceed as recommended with an in-situ bioremediation pilot study was provided in December 1990. The remedial action plan for the Fuel Oil Spill was submitted to the State of Califomia for review in March 1992. In October 
1993, the state approved the use of the bioremediation pilot study for cleanup. An interim remedial measure is being implemented to protect groundwater while the bioremediation pilot study is being constructed and implemented. Construction of the pilot project was completed in FY 95. The first injection phase of the bioremediation phase began in June 1995.

The Navy Landfill Solid Waste Water Quality Assessment Test report was submitted for review on June 29, 1990, as scheduled, recommending the "No Action Alternative." Groundwater monitoring continued through 1994 to address RWQCB concerns. The RWQCB gave permission in November 1994 to prepare a closure plan for the Navy landfill. Acceptable closure should consist of slope stabilization to be compatible with explosive magazines at the base of the landfill.

The Miscellaneous Sites investigation found contaminants present in concentrations far below regulatory guidelines. The report was submitted to the State of California recommending "no further action." The RWQCB agreed to closure of the assessment phase in 1994; no remedial activities were necessary.

Remedial activities associated with the Trudell Auto Repair Shop were completed in September 1990 and the site was closed in December 1990. (DOE procured the land on which the repair shop was located to serve as a buffer zone for the protection of site operations.) 


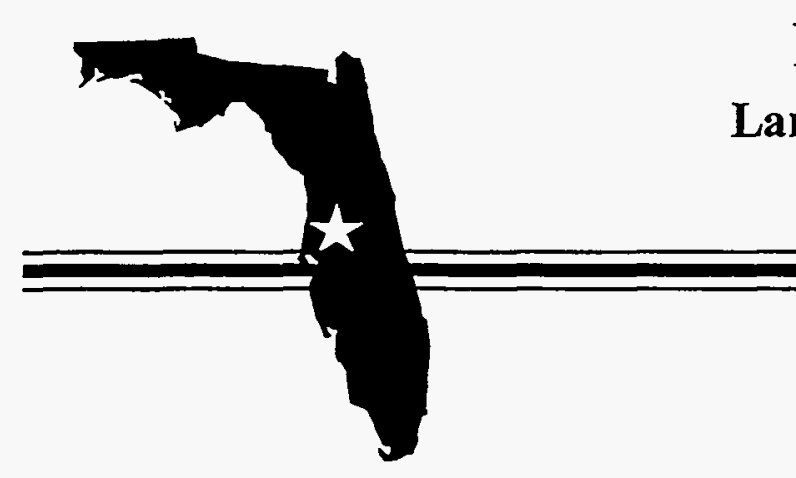

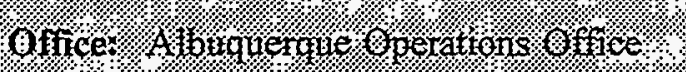

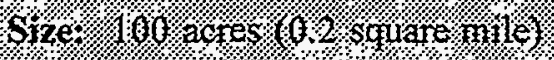

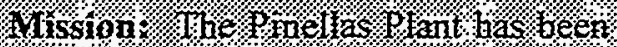

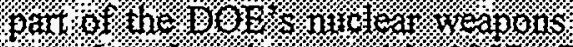

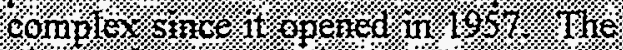

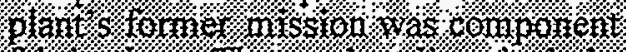

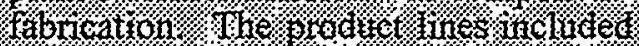

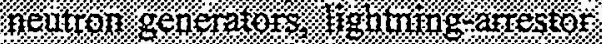

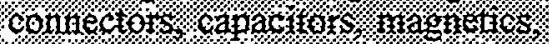

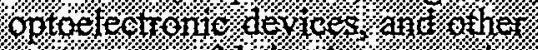

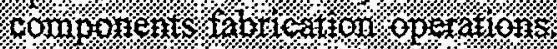

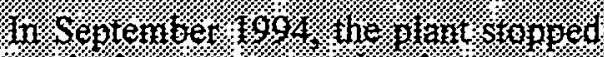

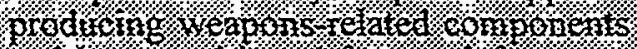

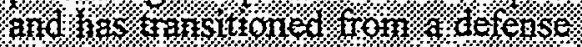

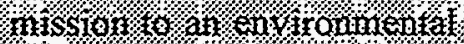

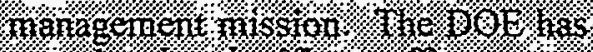

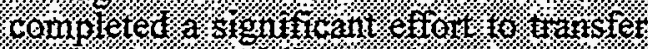

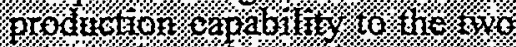

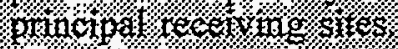

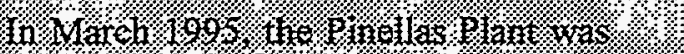

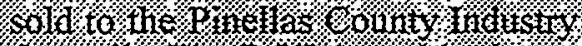

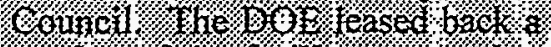

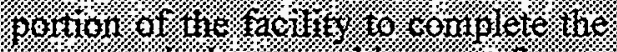

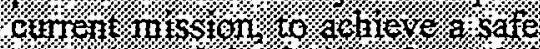

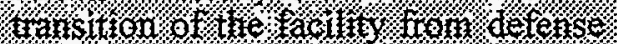

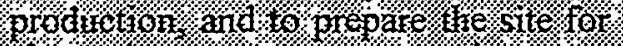

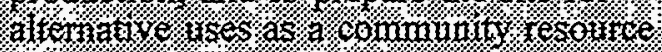

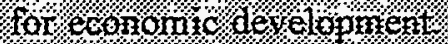

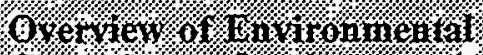

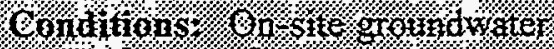

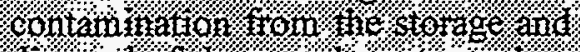

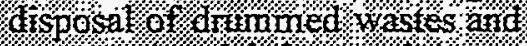

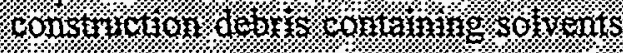

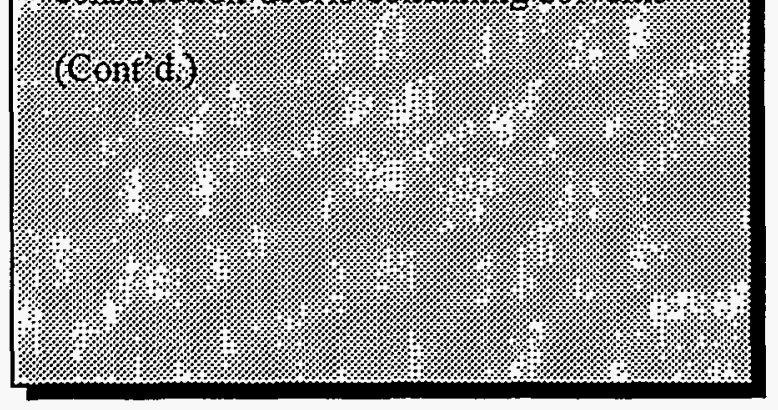

PINELLAS PLANT

Largo, Pinellas County, Florida
Remediation of environmental conditions at the Pinellas Plant is being addressed under authority of a Federal RCRA permit that includes corrective action requirements and cleanup under state Superfund statutes.

\section{Specific Cost Estimates and Budgetary Proposals}

Funds budgeted for environmental restoration at the Pinellas Plant total $\$ 5.9$ million of appropriated funding for FY 96 and $\$ 7.5$ million for FY 97 according to the request in the President's Budget.

\section{Progress in Conducting Remedial Actions}

DOE submitted PA/SI information on the Pinellas Plant to EPA Region IV on October 15, 1987. Remedial activities at the Pinellas Plant are being conducted under a RCRA permit issued February 9, 1990.

Groundwater contamination from volatile organic compounds, due to past plant activities, is the main environmental concern at the Pinellas Plant.

In August 1988, the EPA completed a RFA of the Pinellas Plant. In February 1990, the EPA issued the Pinellas Plant RCRA Hazardous and Solid Waste Amendments permit. This permit identified 15 solid waste management units that may have environmental contamination as a result of past plant activities. Subsequently, three additional solid waste management units were identified. Environmental investigations later revealed that 11 of these units do not pose a threat to public health or the environment. A 12th site (Former Pistol Range), originally identified as requiring a corrective measures study, was addressed by an interim measure shortly after the original investigation. No 


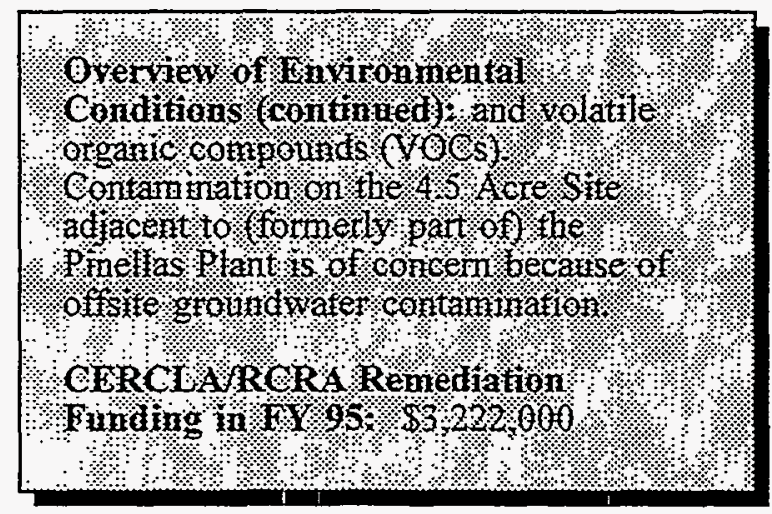

further action is required at this 12 th site. EPA Region IV is currently in the process of modifying the Pinellas Plant RCRA Hazardous and Solid Waste Amendments permit to designate these sites as requiring no further action.

During site characterization and routine soil, water, and groundwater monitoring, plant personnel identified three additional areas: the Production Components Scrap Area, the West Fenceline Area, and the Wastewater Neutralization/Building 200 Area. No hazardous waste or hazardous waste constituents were released to the environment at the Production Components Scrap Area, and EPA directed that no further action was required at this site. The other two sites have groundwater contamination exceeding Federal and state maximum contaminant levels and primary drinking water standards. Consequently, plant personnel completed a RFI for the West Fenceline Area in 1994 and will complete the Facility Investigation for the Wastewater Neutralization/Building 200 Area in 1996.

Additionally, the plant is cleaning up the 4.5 Acre Site, which was sold by DOE to a private party in 1972. A U.S. Geologic Survey in 1985 identified contamination at this site. The Pinellas Plant completed a voluntary assessment and source removal in 1985. The plant is now conducting a voluntary groundwater cleanup at the site following the criteria for state-led CERCLA type actions.

Of the four on-site and one off-site areas identified as requiring further action, interim remedial actions are currently being performed at three sites (Northeast Site, 4.5 Acre Site, and the West Fenceline Area). The interim remedial action at the 4.5 Acre Site consists of groundwater recovery and air stripping the contaminants. The West Fenceline Area has an air sparging/vacuum groundwater extraction system in operation. The Northeast Site is undergoing a groundwater recovery and air stripping of contaminants (currently utilizing the same treatment system as the 4.5 Acre Site), and a buried drum and debris removal action was completed in September 1995. The Pinellas Plant plans to construct an additional air stripping system in fiscal year 1996, which will treat water recovered from both the Northeast Site and Building 100 Area. This additional system, along with any approved innovative technologies, will serve as a final corrective measure for these two sites.

In 1995, DOE received concurrence from EPA Region IV for transfer of the facility as required by CERCLA 120(h). DOE will retain responsibility for ongoing environmental remediation activities, including the plant's Hazardous and Solid Waste Amendments permit as well as the state-led 4.5 Acre Site cleanup.

Radiological environmental contamination is not a Contaminant of Concern at the Pinellas Plant. Decommissioning will not be required at the Pinellas Plant due to proposed future commercial industrial reuse of the building and the fact that only residual contamination will be addressed by the Nuclear Material Facility Stabilization process.

The Pinellas Plant was previously identified as a Potentially Responsible Party at the Peak Oil Superfund Site in Tampa, Florida. A de minimis settlement was executed in September 1995, releasing DOE from any further liability at this Superfund Site. Pinellas Plant involvement in the Zellwood/Drum Services Site (Superfund Site in Zellwood, Florida) is currently under investigation. A response to a CERCLA Section 104(e) information request regarding involvement at this site was completed in June 1992. 


\section{NEVADA TEST SITE}

Nye County, Nevada

tr.

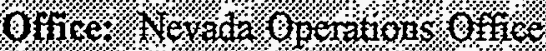

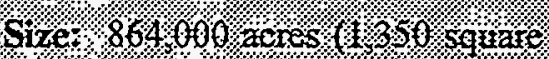
nituts:s:

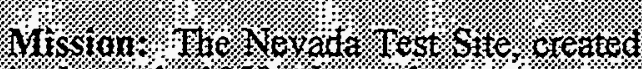

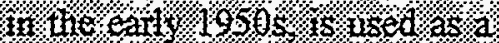

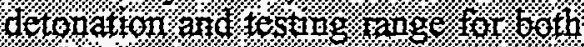

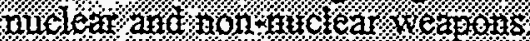

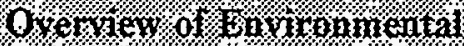

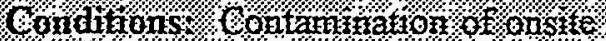

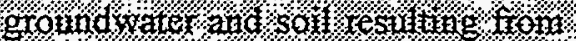

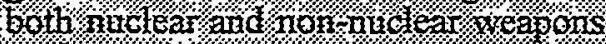
testing activitics.

$$
\text { \% }
$$

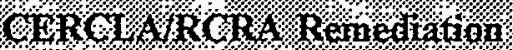

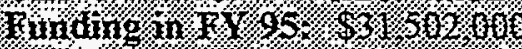

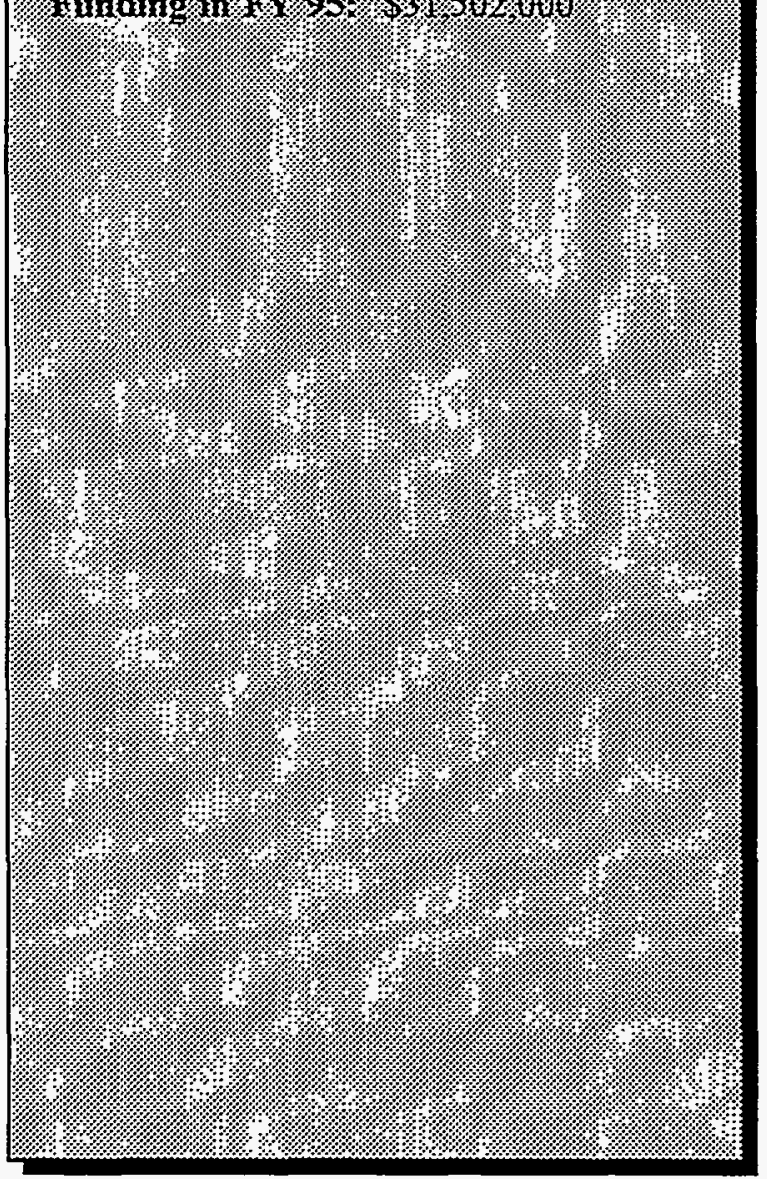

The environmental restoration activities at the Nevada Test Site are being conducted under DOE authorities. Negotiation of an FFA with the State of Nevada was initiated in FY 93 under RCRA and the Atomic Energy Act. Negotiations are expected to be completed during the second quarter of FY 96. A Draft Sitewide Environmental Impact Statement has been prepared and is expected to be distributed for public comment in February 1996.

\section{Specific Cost Estimates and Budgetary Proposals}

Funds budgeted for environmental restoration for Nevada Test Site total $\$ 45.4$ million of appropriated funding for FY 96 and \$51.1 million for FY 97 according to the request in the President's Budget.

\section{Progress in Conducting Remedial Actions}

DOE submitted a PA and draft Hazard Ranking System scores for the Nevada Test Site and eight offsite locations to EPA Region IX on April 15, 1988. DOE has since rescored the Nevada Test Site, using the revised Hazard Ranking System. The Hazard Ranking System package was resubmitted to EPA Region IX in December 1991. The Nevada Test Site is being evaluated for potential listing on the NPL by EPA. Although EPA Region IX recommended that the site be listed, EPA has made no final decision.

Remediation activity undertaken thus far has centered on continued research into the development of a process to remediate large areas of soils contaminated with plutonium from past activities. Five bench-scale technologies have been tested. A preliminary risk assessment and a draft cost benefit analysis for these contaminated soil sites were completed. Technology development of radiation detection systems for plutonium also continued. In 
addition, an effort to identify, verify, and document all potential release sites, known as the Environmental Restoration Sites Inventory, was initiated. Progress on the Underground Test Area Operable Unit also continued.

The Nevada Test Site continues remediation of inactive underground storage tanks.

There were several RCRA closure activities initiated during FY 95. Decommissioning of the Junior Hot Cell and SAFER closure of the 5 Point Landfill at the Tonopah Test Range were completed. The Interim Actions completed during FY 95 included removal of 12 underground storage tanks and 10 abandoned septic tanks. Four assessments were also completed in FY 95.

Work performed during 1995 for the Groundwater Characterization Project, renamed the Underground Test Area RI/FS Project, includes drilling of several new and reconfigured wells, development of a subproject work plan, and data analysis and modeling studies. The Underground Test Area RI/FS project regional groundwater model and risk assessment are scheduled for completion in late 1996. 


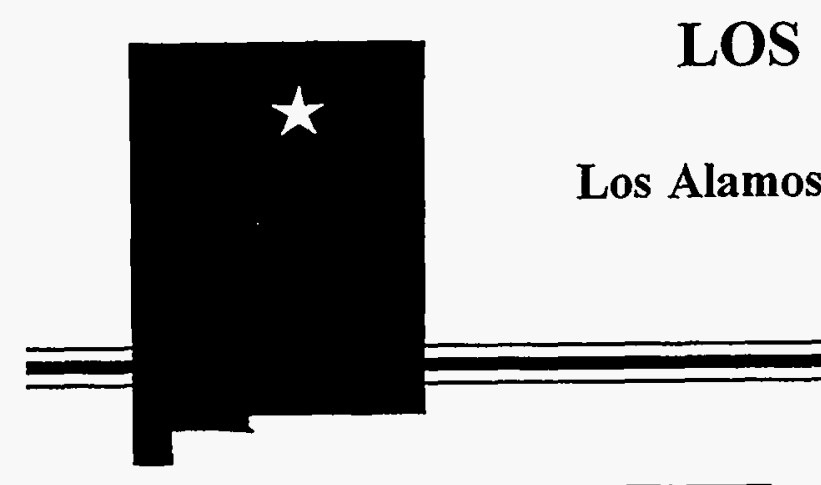

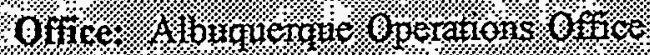

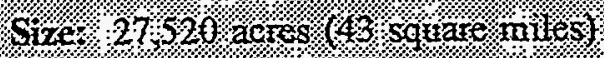

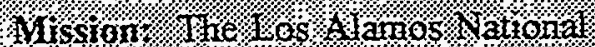

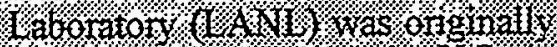

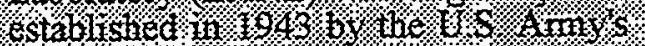

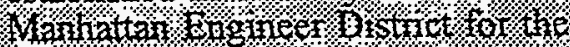

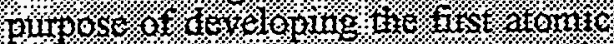

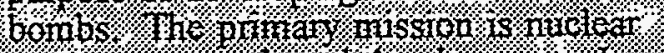

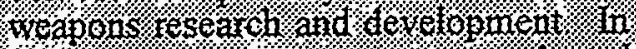

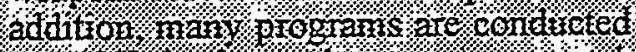

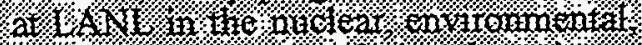

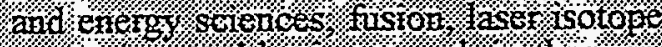

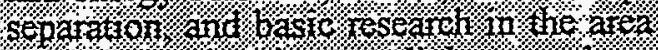

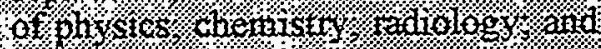
nindincinc

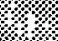

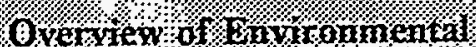

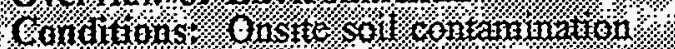

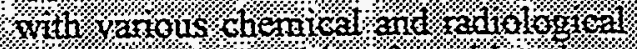

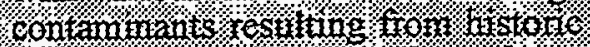

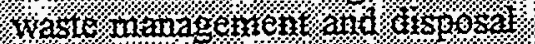

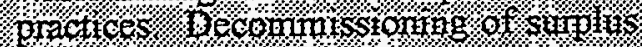

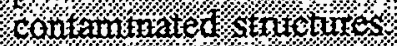

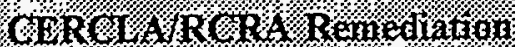

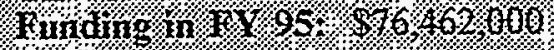

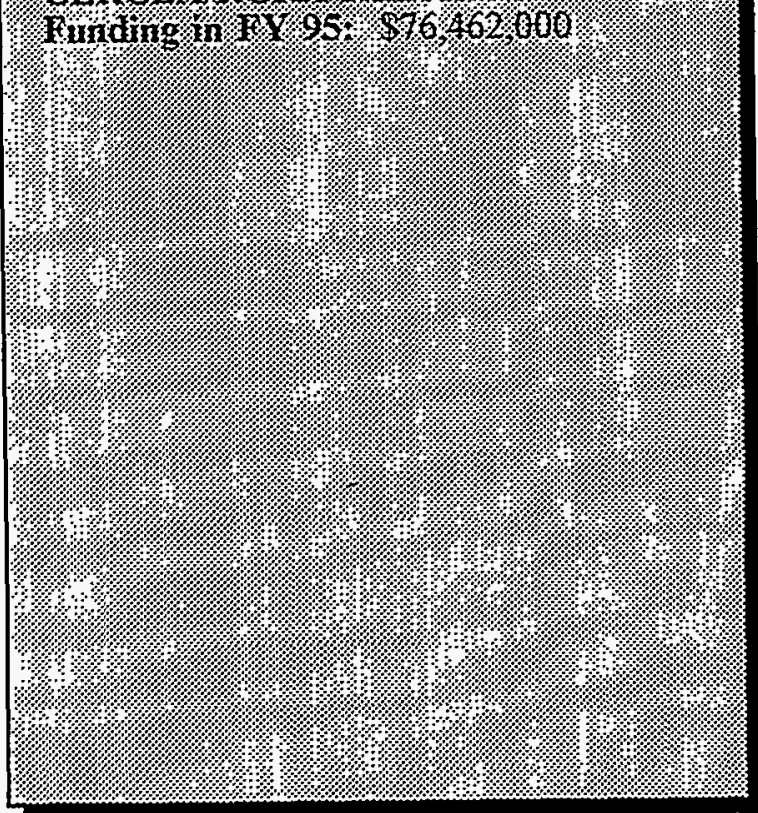

Remediation of environmental conditions at LANL is being addressed under authority of a RCRA permit, which includes corrective action requirements.

\section{Specific Cost Estimates and Budgetary Proposals}

Funds budgeted for environmental restoration at LANL total $\$ 53.6$ million of appropriated funding for FY 96 and $\$ 43.0$ million for FY 97 according to the request in the President's Budget.

\section{Progress in Conducting Remedial Actions}

LANL submitted its PA/SI to EPA on October 15, 1987. When the site was scored using the Hazard Ranking System, LANL did not qualify for inclusion on the NPL.

During FY 95, RFI work was in progress. In addition, some field work associated with RCRA closure requirements has been completed, and several interim remedial measures have been planned to facilitate ongoing construction projects. Decommissioning of TA-21 Buildings 3 and 4 South began in 1993 and continued in FY 95. 
This Page Intentionally Left Blank. 

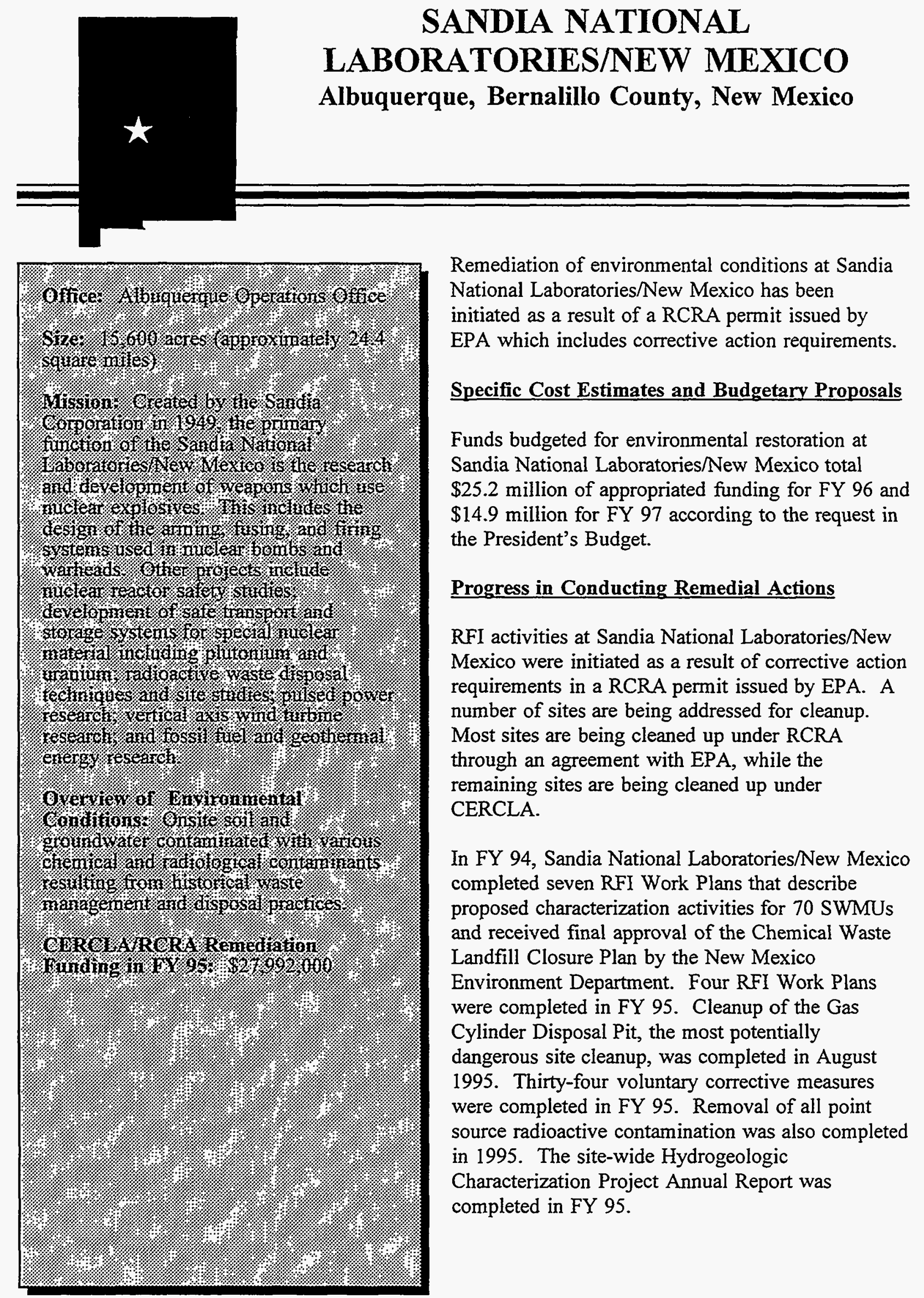

Remediation of environmental conditions at Sandia National Laboratories/New Mexico has been initiated as a result of a RCRA permit issued by EPA which includes corrective action requirements.

\section{$\underline{\text { Specific Cost Estimates and Budgetary Proposals }}$}

Funds budgeted for environmental restoration at Sandia National Laboratories/New Mexico total $\$ 25.2$ million of appropriated funding for FY 96 and $\$ 14.9$ million for FY 97 according to the request in the President's Budget.

\section{Progress in Conducting Remedial Actions}

RFI activities at Sandia National Laboratories/New Mexico were initiated as a result of corrective action requirements in a RCRA permit issued by EPA. A number of sites are being addressed for cleanup. Most sites are being cleaned up under RCRA through an agreement with EPA, while the remaining sites are being cleaned up under CERCLA.

In FY 94, Sandia National Laboratories/New Mexico completed seven RFI Work Plans that describe proposed characterization activities for 70 SWMUs and received final approval of the Chemical Waste Landfill Closure Plan by the New Mexico Environment Department. Four RFI Work Plans were completed in FY 95. Cleanup of the Gas Cylinder Disposal Pit, the most potentially dangerous site cleanup, was completed in August 1995. Thirty-four voluntary corrective measures were completed in FY 95. Removal of all point source radioactive contamination was also completed in 1995. The site-wide Hydrogeologic Characterization Project Annual Report was completed in FY 95. 
This Page Intentionally Left Blank 


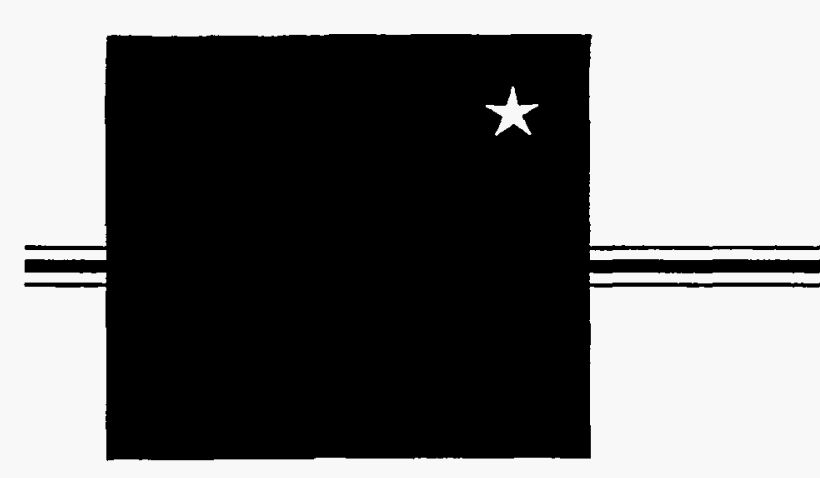

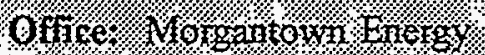

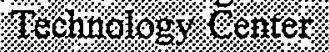

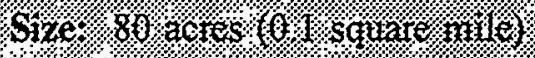

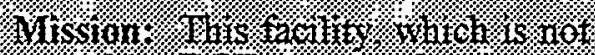

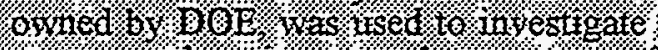

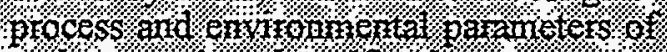

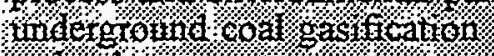
techinolog.t.

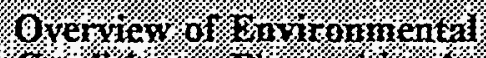

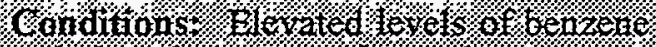
and phenols in ari onsife cont seann

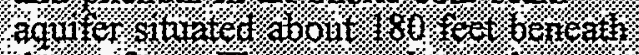

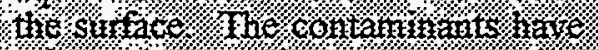

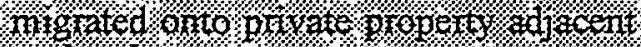
to tite. st:et

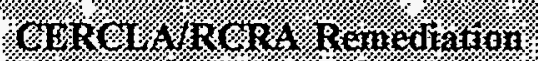

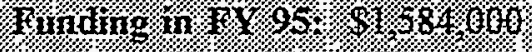

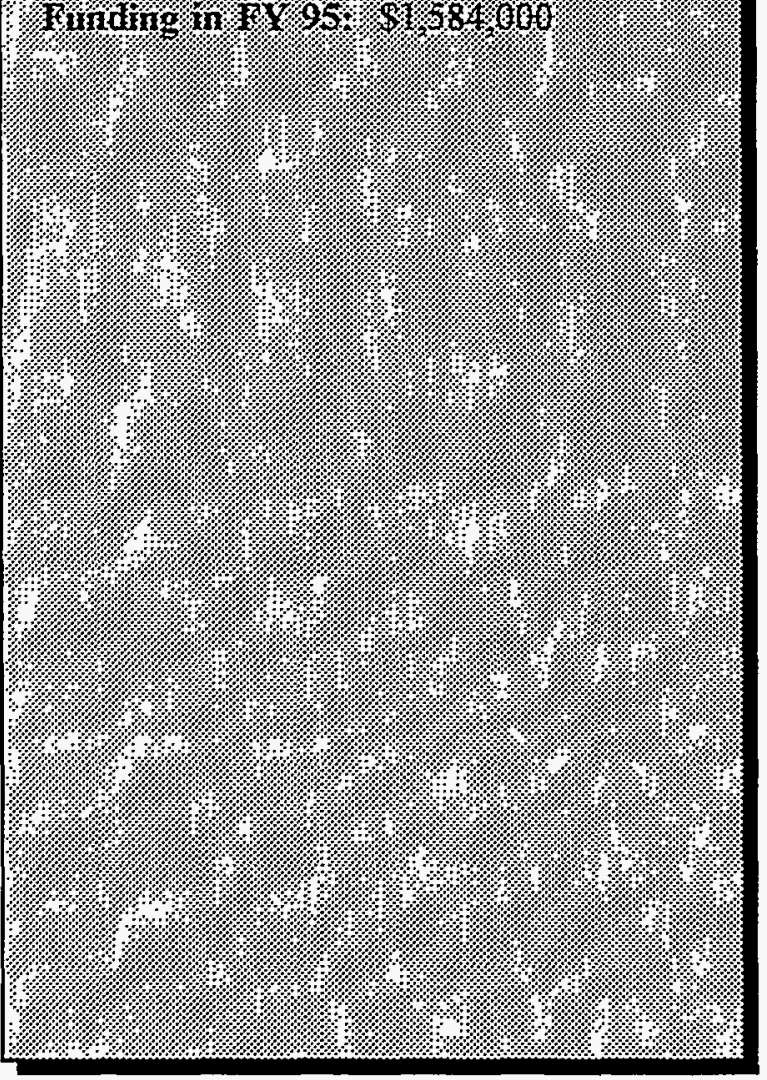

HOE CREEK

Gillette, Wyoming

The Hoe Creek Site is not on the National Priorities List. As a result of the low Hazard Ranking Score, the site was classified as Site Evaluation Accomplished, and DOE was directed to work with the State of Wyoming to determine any site cleanup requirements.

\section{Specific Cost Estimates and Budgetary Proposals}

Funds budgeted for environmental restoration at Hoe Creek total $\$ 3.7$ million of appropriated funding for FY 96 and \$1.5 million for FY 97 according to the request in the President's Budget.

\section{Progress in Conducting Remedial Actions}

During FY 95, the final two rounds of four quarterly groundwater samples were analyzed and the results were used to complete a cleanup alternatives study for the site. The study was performed through an IAG with the Omaha District of the U.S. Army Corps of Engineers. Biosparging (a combination of air injection and biodegradation) was recommended to the State of Wyoming, which agreed to a oneacre, 6-month field demonstration of the recommended alternative. EG\&G TSWV, Inc., the company which is conducting the field demonstration, is scheduled to submit a report by July 1996. It is anticipated that the selected cleanup technology description and schedule will be incorporated into the Wyoming Agreement as an Appendix in early FY 97. 
This Page Intentionally Left Blank. 
APPENDICES

APPENDIX A - LIST OF ACRONYMS AND ABBREVIATIONS APPENDIX B - LISTING OF FACILITIES 


\section{APPENDIX A}

List of Acronyms and Abbreviations

\begin{tabular}{|c|c|}
\hline ANL & Argonne National Laboratory \\
\hline ARA & Auxiliary Reactor Area \\
\hline ARVFS & Army Re-entry Vehicle Facility Storage \\
\hline BORAX & Boiling Water Reactor Experiment Reactor \\
\hline BPA & Bonneville Power Administration \\
\hline CDPHE & Colorado Department of Public Health and Environment \\
\hline CERCLA & Comprehensive Environmental Response, Compensation, and Liability Act \\
\hline COCA & Consent Order and Compliance Agreement \\
\hline DOE & U.S. Department of Energy \\
\hline $\mathrm{EE} / \mathrm{CA}$ & Engineering Evaluation/Cost Analysis \\
\hline $\mathrm{EH}$ & Office of Environment, Safety and Health \\
\hline EM & Office of Environmental Management \\
\hline EPA & U.S. Environmental Protection Agency \\
\hline ERA & Expedited Response Action \\
\hline FEMP & Fernald Environmental Management Project \\
\hline FFA & Federal Facility Agreement \\
\hline FFA/CO & Federal Facility Agreement/Consent Order \\
\hline FR & Federal Register \\
\hline FRVP & Fernald Residues Vitrification Plant \\
\hline FS & Feasibility Study \\
\hline FS/PP & Feasibility Study/Proposed Plan \\
\hline FUSRAP & Formerly Utilized Sites Remedial Action Program \\
\hline FY & Fiscal Year \\
\hline GSA & General Services Area \\
\hline IAG & Interagency Agreement \\
\hline IM/IRA & Interim Measure/Interim Remedial Action \\
\hline NEL & Idaho National Engineering Laboratory \\
\hline IRA & Interim Remedial Action \\
\hline LANL & Los Alamos National Laboratory \\
\hline LBNL & Lawrence Berkeley National Laboratory \\
\hline LEHR & Laboratory for Energy-Related Health Research \\
\hline LLNL & Lawrence Livermore National Laboratory \\
\hline MOA & Memorandum of Agreement \\
\hline NCP & National Contingency Plan \\
\hline NEPA & National Environmental Policy Act \\
\hline NPL & National Priorities List \\
\hline NRF & Naval Reactor Facility \\
\hline ORAU & Oak Ridge Associated Universities \\
\hline ORNL & Oak Ridge National Laboratory \\
\hline
\end{tabular}




\section{APPENDIX A}

List of Acronyms and Abbreviations (Continued)

\begin{tabular}{|c|c|}
\hline ORR & Oak Ridge Reservation \\
\hline OU & Operable Unit \\
\hline PA & Preliminary Assessment \\
\hline $\mathrm{PA} / \mathrm{SI}$ & Preliminary Assessment/Site Investigation \\
\hline PCB & Polychlorinated Biphenyl \\
\hline $\mathrm{PP}$ & Proposed Plan \\
\hline PRP & Potentially Responsible Party \\
\hline RAWP & Remedial Action Work Plan \\
\hline RA & Remedial Action \\
\hline $\mathrm{RCRA}$ & Resource Conservation and Recovery Act \\
\hline RD/RA & Remedial Design/Remedial Action \\
\hline RDWP & Remedial Design Work Plan \\
\hline RFA & RCRA Facility Assessment \\
\hline RFETS & Rocky Flats Environmental Technology Site \\
\hline RFI & RCRA Facility Investigation \\
\hline RFI/RI & RCRA Facility Investigation/Remedial Investigation \\
\hline $\mathrm{RI}$ & Remedial Investigation \\
\hline $\mathrm{RI} / \mathrm{FS}$ & Remedial Investigation/Feasibility Study \\
\hline RI/RA & Remedial Investigation/Remedial Action \\
\hline ROD & Record of Decision \\
\hline RWQCB & Regional Water Quality Control Board \\
\hline SAFER & Streamlined Approach for Environmental Restoration \\
\hline SARA & Superfund Amendments and Reauthorization Act \\
\hline SCDHEC & South Carolina Department of Health and Environmental Control \\
\hline SEA & Site Evaluation Accomplished \\
\hline SI & Site Investigation \\
\hline SITE & Superfund Innovative Technology Evaluation \\
\hline SL-1 & Stationary Low Power Reactor-1 \\
\hline SPRO & Strategic Petroleum Reserve Office \\
\hline SRS & Savannah River Site \\
\hline SWMU & Solid Waste Management Unit \\
\hline SWRI & Site Wide Remedial Investigation \\
\hline TSCA & Toxic Substances Control Act \\
\hline UCD & University of California, Davis \\
\hline UMTRA & Uranium Mill Tailings Remedial Action \\
\hline VOC & Volatile Organic Compound \\
\hline WAG & Waste Area Group \\
\hline WAPA & Western Area Power Administration \\
\hline
\end{tabular}




\section{APPENDIX B}

Index of Individual Facilities

Facility Name

Page Number

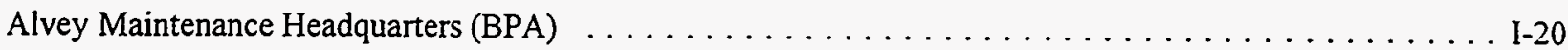

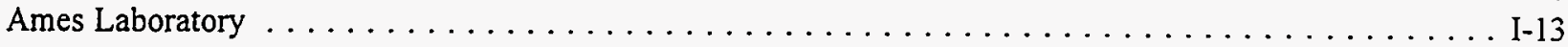

Anvil Points Facility, Naval Oil Shale Reserve No. $3 \ldots \ldots \ldots \ldots \ldots \ldots \ldots \ldots \ldots \ldots \ldots \ldots \ldots$ I-10

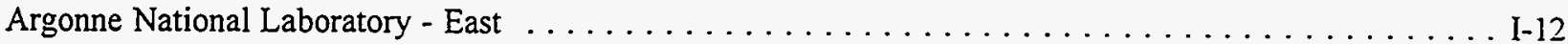

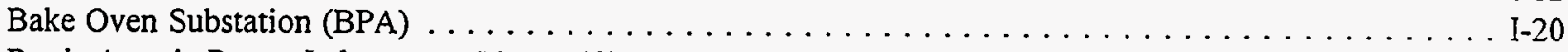

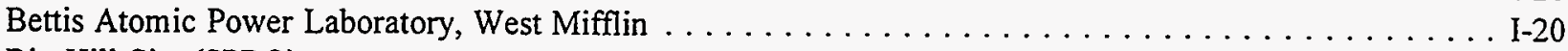

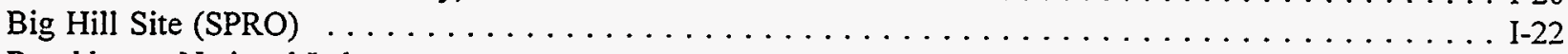

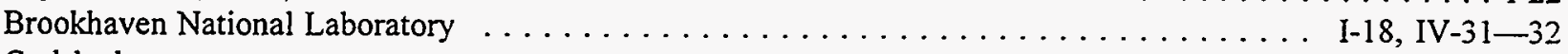

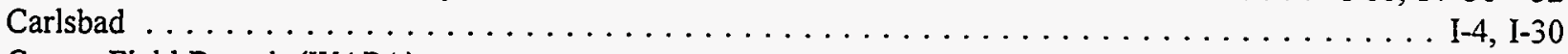

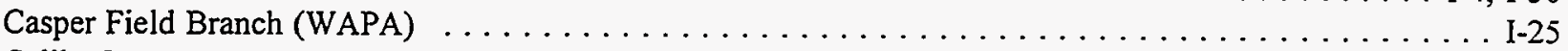

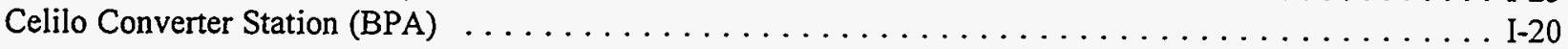

Center for Energy and Environmental Research $\ldots \ldots \ldots \ldots \ldots \ldots \ldots \ldots \ldots \ldots \ldots \ldots \ldots \ldots \ldots \ldots \ldots$

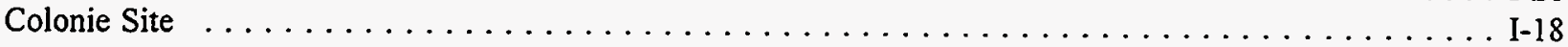

Columbia Basin Project AEC Zone 2,4-D Site $\ldots \ldots \ldots \ldots \ldots \ldots \ldots \ldots \ldots \ldots \ldots \ldots \ldots \ldots \ldots$ I-23

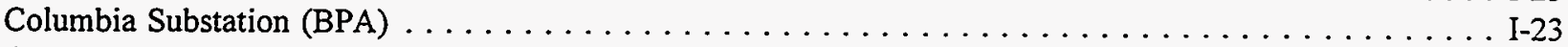

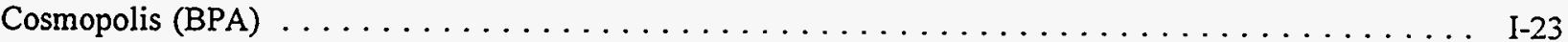

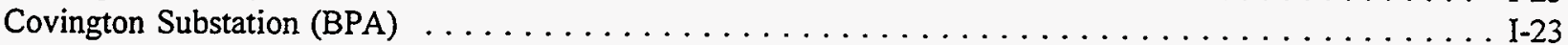

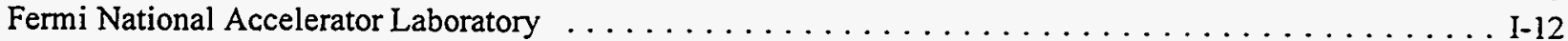

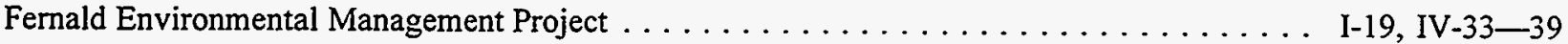

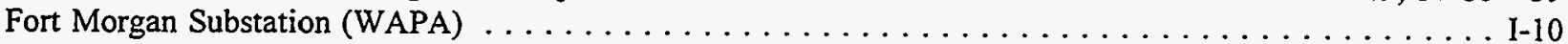

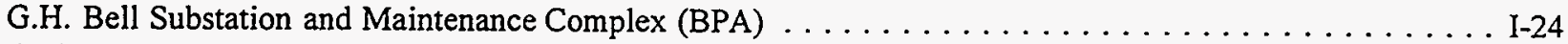

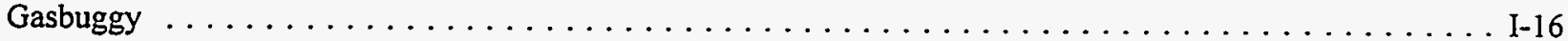

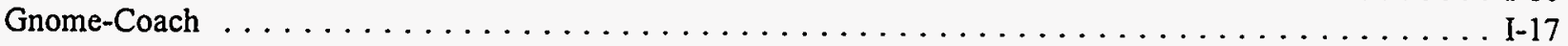

Grand Junction Projects Office Remedial Action Project $\ldots \ldots \ldots \ldots \ldots \ldots \ldots \ldots \ldots \ldots \ldots$ I-10

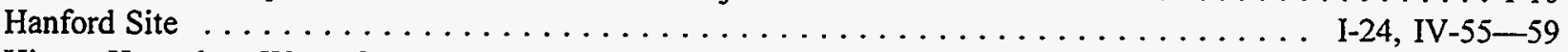

Hinton Hazardous Waste Storage Facility (WAPA) $\ldots \ldots \ldots \ldots \ldots \ldots \ldots \ldots \ldots \ldots \ldots \ldots \ldots \ldots$

Hoe Creek . . . . . . . . . . . . . . . . . . . . $\ldots \ldots \ldots \ldots \ldots$ V 15

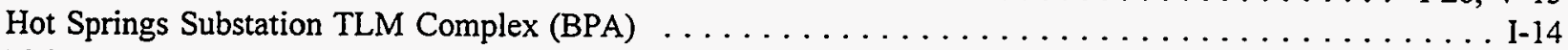

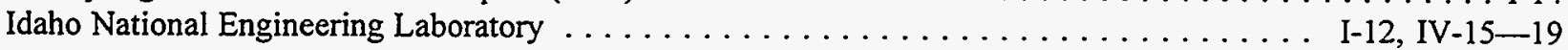

Kansas City Plant . . . . . . . . . . . . . . . . . . . . . . . . . . . . .

Kauai Test Facility . . . . . . . . . . . . . . . . . . . . . . . . . . I -11

Knolls Atomic Power Laboratory, Niskayuna and West Milton Sites $\ldots \ldots \ldots \ldots \ldots \ldots \ldots \ldots \ldots$ I-18

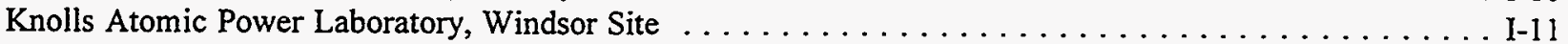

Laboratory for Energy-Related Health Research (LEHR) $\ldots \ldots \ldots \ldots \ldots \ldots \ldots \ldots \ldots$ I-8, IV-3-4

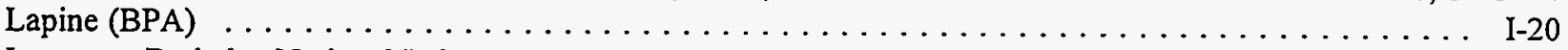

Lawrence Berkeley National Laboratory $\ldots \ldots \ldots \ldots \ldots \ldots \ldots \ldots \ldots \ldots \ldots \ldots \ldots \ldots \ldots \ldots \ldots \ldots$ I-8, V-3

Lawrence Livermore National Laboratory - Livermore Site . . . . . . . . . . . . . . I-8, IV-5-6

Lawrence Livermore National Laboratory - Site $300 \ldots \ldots \ldots \ldots \ldots \ldots \ldots \ldots \ldots$. . . . . IV-7-8

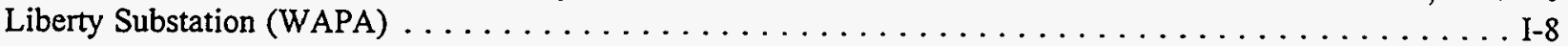

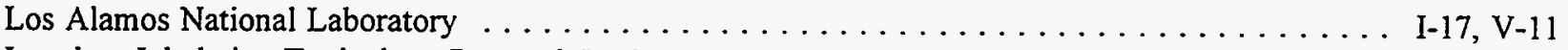

Lovelace Inhalation Toxicology Research Institute $\ldots \ldots \ldots \ldots \ldots \ldots \ldots \ldots \ldots \ldots \ldots \ldots$ I-17

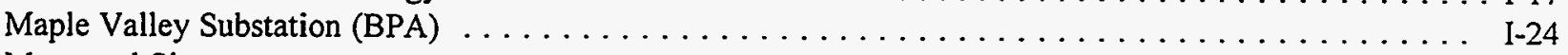

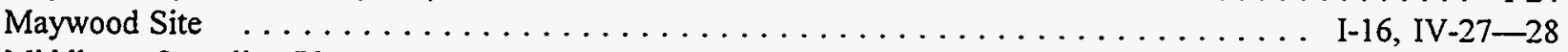

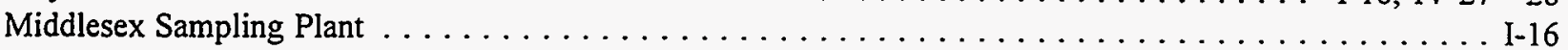

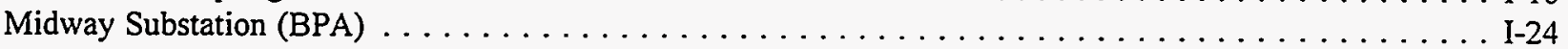

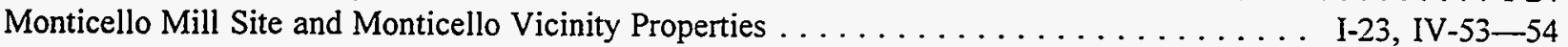

Monroe (BPA) . . . . . . . . . . . . . . . . . . . . . . . . . . . . . I -25

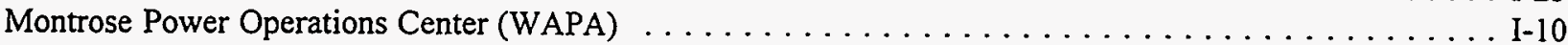

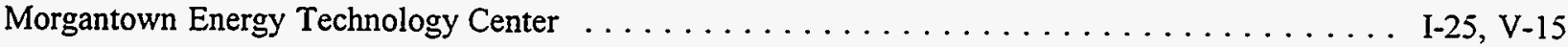




\section{APPENDIX B \\ Index of Individual Facilities (Continued)}

Facility Name

Page Number

Mound Plant

$\mathrm{I}-19, \mathrm{IV}-41-42$

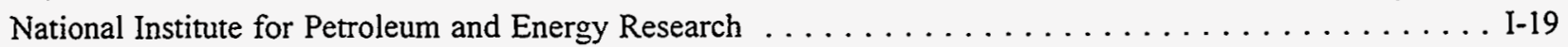

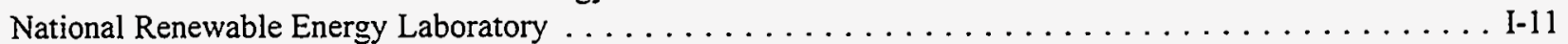

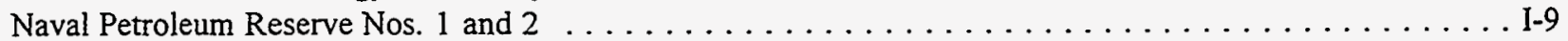

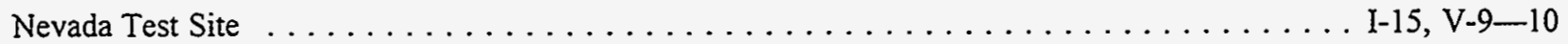

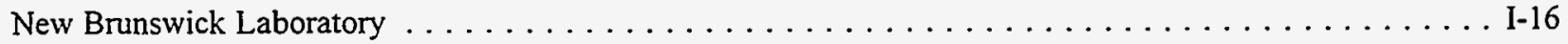

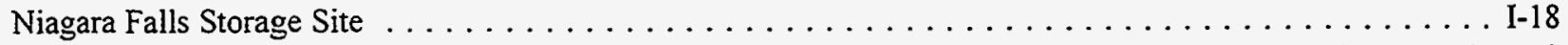

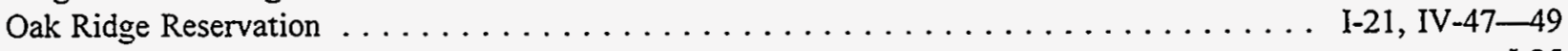

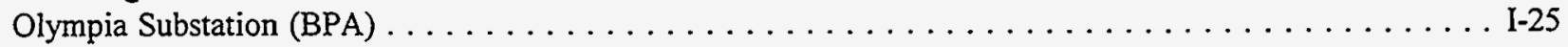

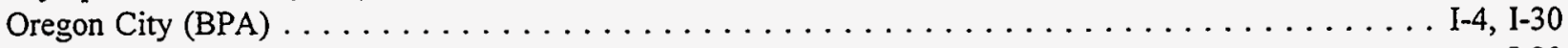

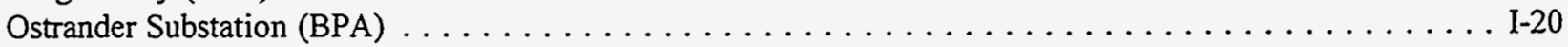

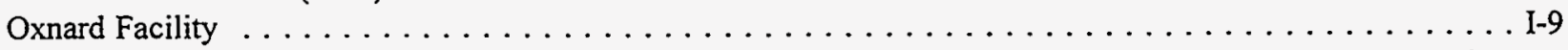

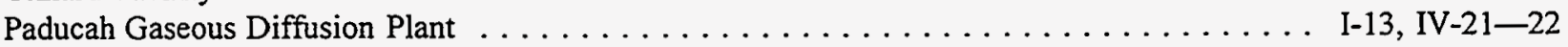

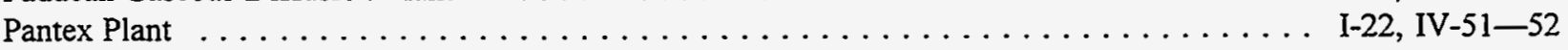

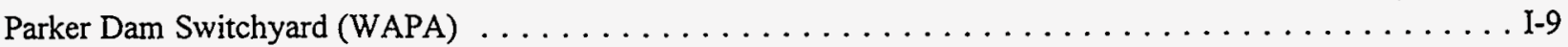

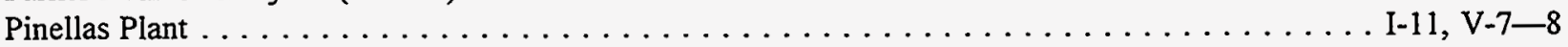

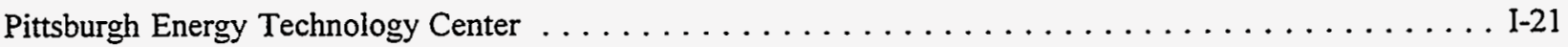

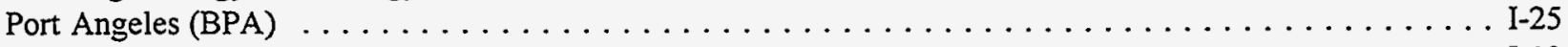

Portsmouth Uranium Enrichment Complex . . . . . . . . . . . . . . . . . . . I-19

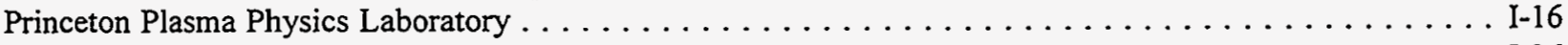

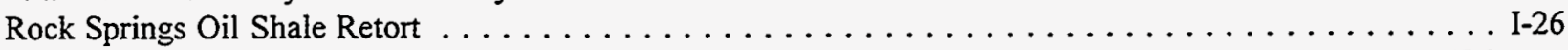

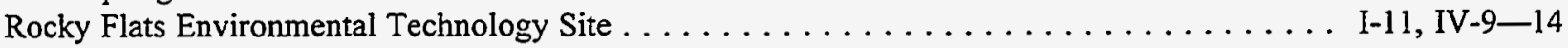

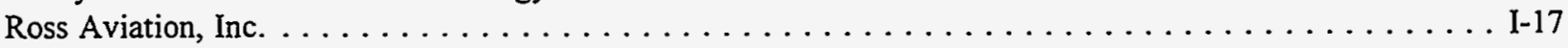

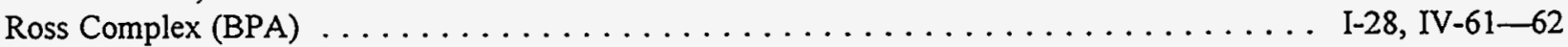

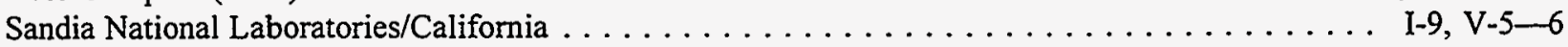

Sandia National Laboratories/New Mexico . . . . . . . . . . . . . . . . . . . . I-17, V-13

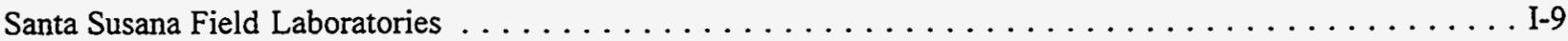

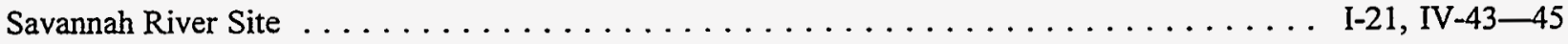

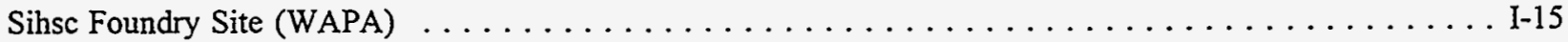

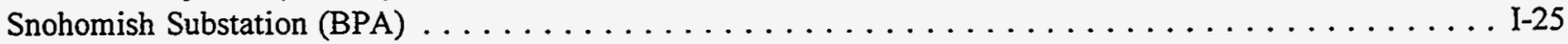

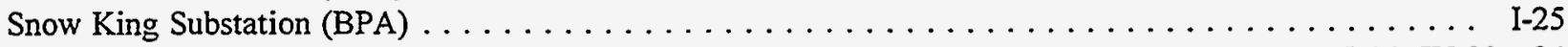

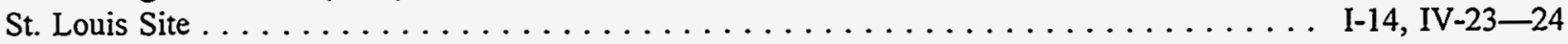

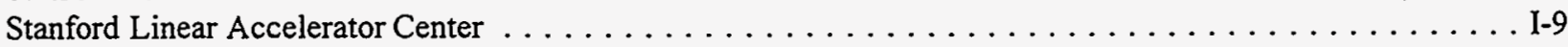

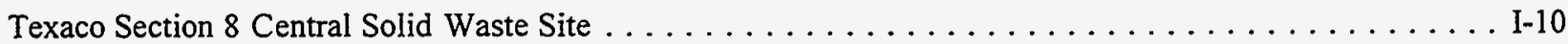

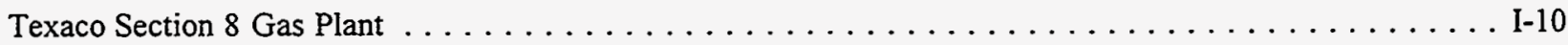

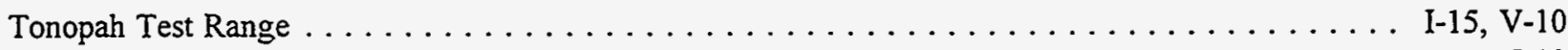

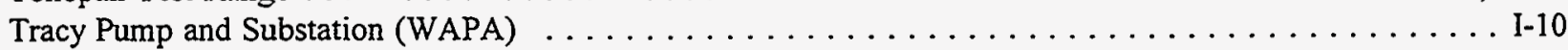

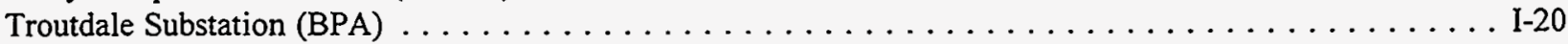

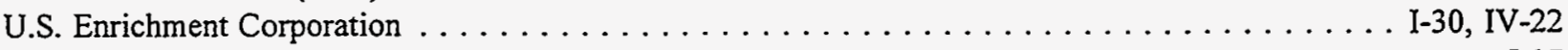

Waste Isolation Pilot Plant $\ldots \ldots \ldots \ldots \ldots \ldots \ldots \ldots \ldots \ldots \ldots \ldots \ldots \ldots \ldots \ldots \ldots \ldots \ldots \ldots \ldots \ldots \ldots .17$

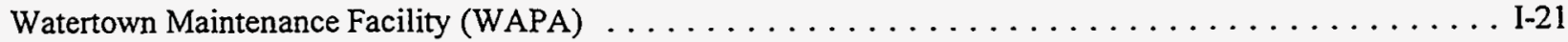

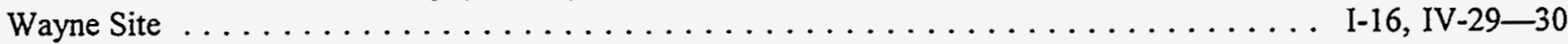

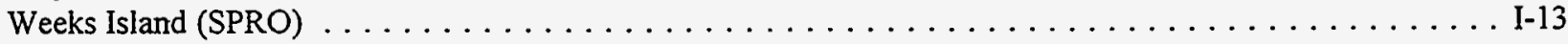

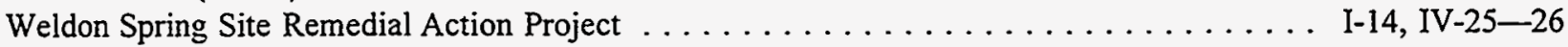

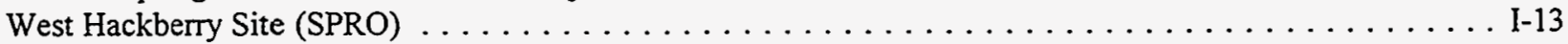

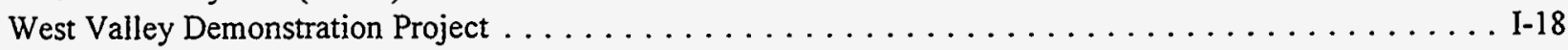

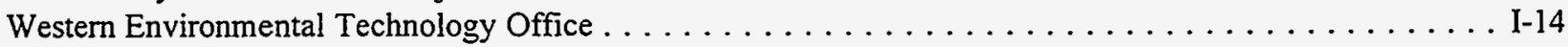

Yucca Mountain Site . . . . . . . . . . . . . . . . . . $\ldots \ldots \ldots \ldots \ldots \ldots$ 